\title{
KMETIJSTVO KOT PRILOŽNOST SONARAVNEGA RAZVOJA PODEŽELJA V SLOVENIJI
}

\author{
Barbara Lampič \\ Oddelek za geografijo Filozofske fakultete Univerze v Ljubljani, \\ Aškerčeva cesta 2, SI - 1000, Ljubljana, Slovenija \\ e-pošta: barbara.lampic@ff.uni-lj.si \\ Izvirni znanstveni članek \\ COBISS 1.01
}

\section{Izvleček}

Vloga kmetijstva na podeželju se je bistveno spremenila, celo povečala, saj se je kmetijstvu pričelo pripisovati številne nove funkcije, od socialne do ekološke. Z vključitvijo v EU in uveljavljanjem Skupne kmetijske politike prihaja do velikih sprememb tudi v slovenskem kmetijstvu, njegovi usmeritvi, stopnji intenzivnosti, velikostni in posestni strukturi. Vprašanje pa je, ali je smer razvoja kmetijstva v Sloveniji v skladu z varovanjem in ohranjanjem naših ključnih naravnih virov?

Ključne besede: kmetijstvo, podeželje, sonaravni razvoj, snovni vnosi kmetijstva, kmetijsko-okoljski ukrepi, učinki kmetijske politike, ekološko kmetijstvo, Slovenija, Evropska unija.

\section{AGRICULTURE AS THE OPPORTUNITY FOR SUSTAINABLE DEVELOPMENT OF SLOVENE RURAL AREAS}

\begin{abstract}
The role of agriculture in rural areas has changed significantly, it has even increased, since having been attributed numerous new functions, from social to ecologic. Also Slovene agriculture, its direction, intensity level, size and proprietal structure was subject to considerable changes as a result of inclusion of Slovenia in the EU and implementation of the Common Agricultural Policy. However it should be considered whether the direction of development of Slovene agriculture corresponds to protection and conservation of our major natural resources?
\end{abstract}

Key words: agriculture, rural areas, sustainable development, agricultural material inputs, agri-environment measures, impact of agricultural policy, organic farming, Slovenia, European Union. 


\section{UVOD}

Temeljno vprašanje, ki se danes zastavlja pri obravnavanju kmetijstva, je njegov pomen in dejanska vloga $v$ širšem razvoju (podeželja). Priče smo vse večjim prizadevanjem kmetijskih in okoljskih politik v usmerjanje razvoja kmetijstva $v$ ohranjanje in varovanje okolja. Glede na dosedanji razvoj pa si zastavljamo vprašanje, v kolikšni meri je slovensko kmetijstvo že pomembnejši nosilec funkcije varovanja okolja s poudarkom na ključnih naravnih virih in kje so naše največje priložnosti, da z načrtnim usmerjanjem sonaravnih oblik kmetovanja oblikujemo in vzpodbudimo trajnostni razvoj slovenskega podeželja.

Izhajajoč iz trenutnih razmer v kmetijstvu kot pomembnemu dejavniku razvoja podeželja ter ključnemu oblikovalcu kulturne pokrajine in upoštevajoč aktualne in bodoče spremembe po vstopu v Evropsko unijo (EU), je v prispevku posebej izpostavljeno:

- Novo razumevanje kmetijstva s poudarkom na njegovi multifunkcionalnosti, ki v geografskih krogih ni novo, predstavlja pa drugačen pristop v vse bolj eko-socialno naravnani skupni kmetijski politiki (SKP).

- Analiza stanja v kmetijstvu z vidika njegovega aktualnega obremenjevanja. Na podlagi obsežnih podatkov iz preteklih let ter dodatnih novih raziskav v zadnjih dveh letih (Terensko delo, FF, Oddelek za geografijo, 2004-2005), želimo izpostaviti glavne smeri razvoja slovenskega kmetijstva predvsem z vidika obremenjevanja okolja.

- Vpliv spremenjene kmetijske politike, ki se odraža $v$ vrstah in obsegu izvajanja različnih ukrepov. Podrobna analiza izvajanja izbranih kmetijskih ukrepov s poudarkom na kmetijsko okoljskih ukrepih ter ustrezni prostorski prikazi na ravni občin, ob upoštevanju naravnih razmer, prikazujejo ustreznost zastopanosti posameznih ukrepov. Še poseben poudarek je na ukrepih za zmanjševanje negativnih vplivov kmetijstva na okolje, ki kažejo dejansko stopnjo uresničevanja v programih zastavljenih ciljev, hkrati pa opozarjajo na pomanjkanje ciljne usmerjenosti posameznih ukrepov.

- Obstoječe stanje na področju sonaravnih oblik kmetovanja v Sloveniji skupaj z možnostmi usmerjanja kmetijstva v skladu s paradigmo trajnostnega razvoja. Končen rezultat predstavlja opredelitev tiste vloge kmetijstva, ki ohranja in varuje pretežni del slovenskega podeželja. Poudariti želimo potrebe in možnosti po večjem uveljavljanju človeku in okolju prijaznejših načinov kmetovanja. Poleg predstavitve vzrokov za razvoj in uveljavljanje sonaravnejših oblik kmetovanja želimo posebej izpostaviti razširjenost ekološkega kmetovanja in njegove razvojne perspektive.

Zaradi pomembnega vpliva kmetijstva na pokrajino/okolje oziroma pokrajinotvorne sestavine, je smiseln še en vidik obravnavanja značilnosti kmetijstva. Nanj lahko gledamo kot na ohranjevalca pokrajine ali kot zgolj na proizvodno dejavnost, ki jo z intenzifikacijo vse bolj označujeta raba naravnih virov in obremenjevanje okolja.

V različnih obdobjih razvoja kmetijske dejavnosti in za različne oblike kmetovanja so seveda izstopajoče določene značilnosti. Če se še pred nekaj desetletji ni nihče zavedal oziroma ni izpostavljal velikih negativnih učinkov kmetijske dejavnosti v okolju, pa je v zadnjem obdobju izrazito poudarjena negativna okoljska vloga intenzivnega in specializiranega 
kmetijstva. Hkrati pa smo priče usmerjanju v sonaravnejše oblike kmetovanja in tako kmetijstvo ponovno pridobiva vloge ne le pridelovalca (v smislu gole »proizvodnje«) ampak vse pomembnejše socialne in ekološke. Vendar je potrebno poudariti, da zgolj »v ohranjanje narave« usmerjeno kmetijstvo ne prispeva k trajnostnemu razvoju.

Z vidika udejanjanja okoljskega razvoja Slovenije na področju kmetijstva, se na eni strani soočamo $\mathrm{z}$ nadaljevanjem intenziviranja in specializacijo kmetijstva (na kmetijsko najprimernejših območjih prodnih ravnin in deloma terciarnega gričevja), hkrati pa se povečuje število ekoloških in integriranih pridelovalcev in delež ekološko obdelanih zemljišč.

Strategija razvoja kmetijstva držav EU je, predvsem v novih članicah, posebno pozornost posvetila oblikovanju in uvajanju kmetijsko okoljskih ukrepov. Odkar so leta 1992 pričeli finančno podpirati okoljsko ustreznejše in biološki pestrosti naklonjene kmetijske prakse, kmetijska politika vse bolj v ospredje postavlja vlogo kmetijstva in kmetov, ki jo imajo pri zagotavljanju okoljskih storitev. V zadnjem programskem obdobju so za države članice EU kmetijsko okoljski ukrepi edina skupina ukrepov, ki je obvezna v okviru izvajanja programov razvoja podeželja.

Kljub na začetku devetdesetih let 20. stoletja reformirani kmetijski politiki, pa se v pretežnem delu Evrope že dlje časa soočajo s problemi izrazito negativnih vplivov kmetijstva na okolje, v prvi vrsti prav na kakovost naravnih virov (vode, prsti), biološko raznovrstnost in obsežne spremembe $\mathrm{v}$ pokrajini. In prav spremembe tako v okoljski kot kmetijski zakonodaji predstavljajo odzive družbe na aktualno, ponekod že alarmantno stanje v okolju.

V Sloveniji je bil leta 2001 v okviru Programa razvoja podeželja (PRP) 2001-2006 sprejet prvi Slovenski kmetijsko okoljski program (SKOP), katerega osnovni namen je usmerjanje kmetijstva $\mathrm{v}$ takšne oblike in načine pridelave, ki ustrezajo potrebam prebivalstva-potrošnikov, varujejo okolje in zdravje ljudi, zagotavljajo trajnostno rabo naravnih virov in ohranjanje biotske pestrosti ter značilnosti slovenske pokrajine.

Strateške usmeritve SKOP-a določa Program reforme kmetijske politike (MKGP, 1998). V celoti se je izvajanje vseh 21 ukrepov pričelo šele leta 2004, med trenutno sedem ukrepov za zmanjševanje negativnih vplivov kmetijstva na okolje pa se uvršča tudi ekološko kmetovanje kot izrazito sonaravno usmerjena oblika kmetovanja. V Sloveniji so se posamezne ekološke kmetije pojavile že v zgodnjih devetdesetih, o pravem razvoju in hitri rasti pa lahko pri nas govorimo predvsem po letu 1999, ko se je začelo subvencioniranje ekološkega kmetijstva.

Do pomembnega zasuka v usmeritvi slovenske kmetijske politike pa ni prišlo zaradi dejanske potrebe in lastne samoiniciativnosti ampak zaradi sprememb v SKP. Zato tudi pri nas (kot se je pokazalo v številnih drugih evropskih državah) obstaja nevarnost, da uvajanje različnih ukrepov ni v skladu z dejanskimi potrebami, kar v veliki meri lahko velja tudi za uvajanje kmetijsko okoljskih ukrepov.

Obsežne geografske raziskave agrarnega obremenjevanja v različnih slovenskih pokrajinah, ki so načrtno in sistematično potekale v devetdesetih letih 20. stoletja, so opozorile na obseg, vrste in razporeditev kmetijskih pritiskov. Na podlagi teh rezultatov ter $\mathrm{z}$ dodatno raziskavo značilnosti kmetij ( $v$ sicer bistveno manjšem obsegu) pa skupaj s stanjem kakovosti ključnih naravnih virov (z vidika kmetijskega obremenjevanja se v Sloveniji najbolj očitno kažejo konflikti z zalogami pitne vode, ohranjanjem biotske pestrosti in varova- 
njem narave) želimo izpostaviti pomembnejše dejavnike, ki so vplivali in še učinkujejo na spremembe $\mathrm{v}$ kmetijstvu, obseg in intenzivnost kmetijske pridelave in na podobo podeželja v celoti.

\section{NOVI POGLEDI NA KMETIJSTVO IN ODNOS DO OKOLJA}

Po desetletjih hitrega razvoja vseh gospodarskih dejavnosti vključno s kmetijstvom, so preštevilna opozorila, v obliki različnih okoljskih, marsikje tudi zdravstvenih in gospodarskih problemov, opozorila na potrebo po ekologizaciji celotne družbe. Ta se najbolje odraža $\mathrm{v}$ temeljitih spremembah obstoječe zakonodaje in uvajanju nove.

\section{Ključni mejniki v kmetijski politiki EU}

Po ustanovitvi Evropske gospodarske skupnosti (EGS) v drugi polovici petdesetih let 20. stoletja ter ob začetku delovanja Skupne kmetijske politike (SKP), je bila večina proračunskih sredstev v kmetijstvu namenjena tržno-cenovni politiki in zelo malo ukrepom strukturne politike. Osrednji cilji kmetijske politike so bili osredotočeni na povečanje produktivnosti v kmetijstvu, stabilizaciji evropskega trga s hrano, zagotavljanju sprejemljivih cen hrane ob ohranjanju zadovoljivega življenjskega standarda podeželskega, takrat še pretežno kmečkega prebivalstva. Vendar je takšna politika pripeljala do povečevanja razlik v razvitosti med različnimi podeželskimi območji. Gospodarska recesija $\mathrm{v}$ sedemdesetih je ob splošnem gospodarskem nazadovanju in neučinkovitem izvajanju strukturne politike pripeljala do nazadovanja podeželja in predvsem do razlik v razvoju med podeželskimi in urbanimi regijami (Erjavec, 1997).

Prvi poskus uvajanja regionalnopolitičnega vidika $\mathrm{v}$ strukturno kmetijsko politiko sredi sedemdesetih je bila delitev podeželskega prostora na tri »težavnostna območja « ${ }^{1} \mathrm{z}$ glavnim ciljem zmanjševanja razlik in izoliranosti t. im. perifernih podeželskih območij. Tak pristop pa je samo delno ublažil razlike, dolgoročno pa se je sprva le gospodarska odvisnost perifernih območij od centralnih prenesla še na politično, administrativno in kulturno področje (Kerber, 2004). Ukrepe klasične regionalne politike so $\mathrm{v}$ osemdesetih pričeli reševati $\mathrm{s}$ konceptom endogenega razvoja, kjer $\mathrm{z}$ integralnim pristopom $\mathrm{v}$ program zajamejo gospodarske, kulturne, politične, socialne in okoljske vidike. Gre za model razvoja, ki v prvi vrsti želi zmanjšati odvisnost območja/regije od zunanjih faktorjev ter hkrati razvoj oblikovati na učinkoviti izrabi lastnih potencialov. Prišlo je do temeljite prenove strukturne kmetijske in regionalne politike, katere osrednji cilj je postal celovit razvoj podeželja, v katerem ima kmetijstvo pomembno vlogo. Kmalu pa se je pokazalo, da je potrebno za učinkovito izvajanje reform strukturne politike prenoviti tudi SKP, ki je vse do devetdesetih let 20. stol. še vedno skušala slediti ciljem ohranjanja poseljenosti in enakomernega regionalnega razvoja predvsem s tržnimi intervencijami in cenovno podporo (Kerber, 2004).

\footnotetext{
${ }^{1}$ Podeželski prostor v državah EGS so opredelili kot problemska območja tam, kjer je prevladovalo hribovsko in gorsko kmetijstvo, omočja z nizko gostoto prebivalstva in območja s specifičnimi problemi.
} 
Ob zanemarjanju razlik v razvoju, pa je kmetijska politika uspela v smislu zagotavljanja ustrezne količine hrane, kar dokazujejo tako pogosti presežki pridelave v preteklih desetletjih, kot obseg izvoza hrane, ki se je neprestano povečeval. Vendar je uspeh $\mathrm{v}$ obsegu pridelave vsa pretekla desetletja šel pravzaprav še najbolj na račun kakovosti okolja.

Reforma SKP leta 1992 je z uvedbo programov razvoja podeželja in predvsem kmetijsko okoljskih programov v sami strukturi Evropskega kmetijskega jamstvenega in usmerjevalnega sklada $\left(\right.$ EKJUS $^{2}$ ) tudi navzven pokazala na pomemben preobrat $\mathrm{v}$ odnosu kmetijstva do okolja in naraščajočih okoljskih problemov. Ukrepi v okviru Razvoja podeželja, imenovani tudi drugi steber kmetijske politike, predstavljajo začetek spremembe v strukturi financiranja, saj se postopoma povečuje delež subvencij, ki so neodvisne od količine pridelave (postopen prenos plačil iz prvega $\mathrm{v}$ drugi steber). Z Agendo 2000 se sicer proces reforme SKP nadaljuje, vendar gledano $v$ celoti spet prevladajo cilji povezani s tržno in finančno politiko. Velja pa poudariti, da je bila eden od ciljev omenjene reforme večje vključevanje okoljskih prioritet $\mathrm{v}$ SKP. Obe reformi sta pomembno zmanjšali do tedaj izrazito zapostavljenost ekstenzivnega kmetovanja z znižano stopnjo finančnih podpor za vrsto pridelkov in živinorejo in hkrati z uvedbo nadomestnih plačil.

Na postopno uveljavljanje t. im. eko-socialnega razvoja kmetijstva kaže že delež sredstev v državah EU, ki je namenjen razvoju podeželja. Delež sredstev jamstvenega sklada je za razvoj podeželja še leta 2000 v državah EU predstavljal komaj 10,3 \%. Povprečno plačilo na hektar kmetijskih zemljišč je znašalo $32 €$, vendar so med posameznimi državami velike razlike. Najučinkoviteje izrabljajo ukrepe drugega stebra ekstenzivnejše kemtijske pridelovalke (Finska, Avstrija, Irska), kjer so povprečna plačila na hektar celo petkrat višja od evropskega povprečja (150€ na Finskem). (The CAPacitty building manual, 2003). Razporeditev sredstev znotraj drugega stebra oz. razvoja podeželja pa nakazuje, ali v posamezni državi prevladujejo okoljske ali socialne podpore v kmetijski politiki.

Stanje v državah EU-15 v leta 2002 kaže, da je bil v ospredju okoljski vidik financiranja razvoja kmetijstva, saj je bilo za kmetijsko okoljske ukrepe namenjenih 43,4 \% (ře leta 2000 je bilo za to skupino ukrepov namenjenih skoraj $55 \%$ sredstev), za izrazito socialne ukrepe (podpora mladim kmetom, zgodnje upokojevanje) pa manj kot $7 \%$. Vendar so razlike med državami članicami velike. Ker želimo predstaviti predvsem vplive kmetijske politike na okoljske sestavine, je ključna zastopanost kmetijsko okoljskih ukrepov oziroma delež sredstev, ki je namenjenem njihovemu financiranju.

Po podatkih za leto 2000 so več sredstev od evropskega povprečja za kmetijsko okoljske ukrepe namenili v Veliki Britaniji, Avstriji, na Portugalskem, Italiji in na Švedskem, kjer je bilo kar $96 \%$ vseh sredstev za razvoj podeželja namenjenih izvajanju kmetijsko okoljskih ukrepov.

Zadnji korak v reformiranju SKP pomeni reforma iz leta 2003, ki je vsaj deloma odgovorila na resne kritike nesonaravno in netrajnostno naravnane SKP. Bistven preobrat pomeni nepovezanost podpor s kmetijsko proizvodnjo, kar je ključnega pomena za spodbujanje in obstoj ekstenzivnejših kmetijskih sistemov.

\footnotetext{
${ }^{2}$ EAGGF;European Agricultural Guidance and Guarantee Fund
} 
Karta 1: Delež sredstev namenjen kmetijsko okoljskim ukrepom v državah EU-15 leta 2000

Map 1: The share of financial means earmrk for agri-environment measures in EU-15 in year 2000

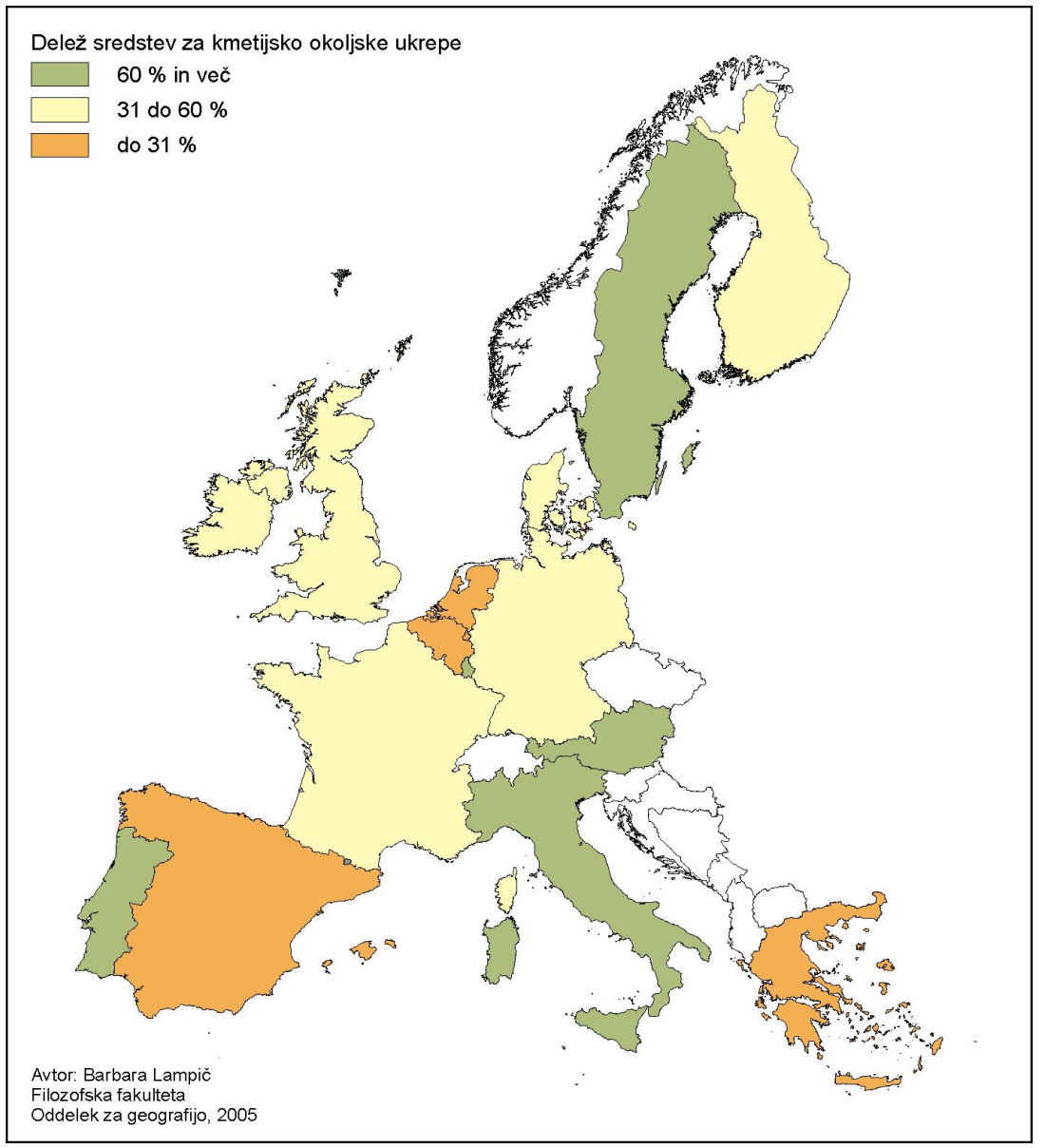

Vir: Ribbe, 2002.

Funkcioniranje podeželskega prostora se je z novimi razvojnimi vzgibi postopoma pričelo spreminjati, pri razvoju podeželja in krepitvi lokalne ekonomije pa imajo poleg ustrezne infrastrukture vse pomembnejšo vlogo alternativne oblike dohodka (razvoj obrti, turizma ipd.), oblikovanje in uveljavljanje regionalnih produktov, razvoj turistično-rekreacijske funkcije podeželja, varovanje okolja skupaj z ohranjanjem narave idr.

Razvoj kmetijstva pa bo v prihodnje zaznamovalo izboljšanje učinkovitosti kmetovanja, upravljanje $\mathrm{z}$ naravo in kulturno pokrajino, zmanjševanje okoljskih vplivov, pomoči pri usmerjanju $\mathrm{v}$ sonaravno kmetovanje, diverzifikacija kmetijske proizvodnje, alternativne oblike dohodka in razvoj različnih storitvenih dejavnosti ter poudarjena vloga gozdov (The CAPacity building manual, 2003). 
Graf 1: Krepitev lokalne ekonomije na podeželju

Figure 1: The strengthening of rural areas local economy

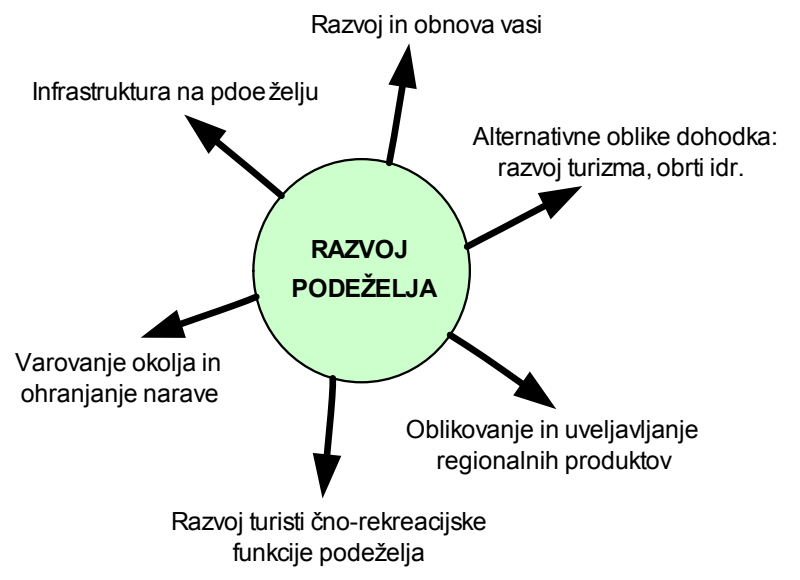

Vir: The CAPacity building manual, 2003.

\section{Okoljska naravnanost Skupne kmetijske politike}

Kljub velikim spremembam SKP po letu 1992, pa številne analize izvajanja različnih ukrepov po skoraj 15-ih letih ugotavljajo, da so učinki spremenjene kmetijske politike marsikje vprašljivi. Še posebej to velja za »okoljsko učinkovitost sprememb«. Vpliv zadnjih sprememb, predvsem nepovezanost podpor s kmetijsko proizvodnjo in vključevanje okoljskega vidika $v$ ukrepe politike prvega (tržnega) in drugega stebra, ki jih prinaša reforma iz leta 2003, se bo pričel kazati šele z njihovim postopnim uveljavljanjem. Dosedanja vsebina in delovanje SKP pa je bila glede na učinke analizirana in ovrednotena v različnih študijah, najnatančneje v študiji Observations on the Environmental Compatibility of the EU Agrcultural Budget iz leta 2002.

Dejansko že vsebina ukrepov jamstvenega sklada in predvsem razporeditev sredstev znotraj tega fonda kažejo, da je povezava med kmetijsko politiko in zahtevami varstva okolja in trajnostnega razvoja prisotna $v$ manjši meri, $v$ določenih segmentih pa celo $v$ nasprotju z okoljevarstvenimi principi razvoja. Večina sredstev sklada, ki je namenjena neposrednim plačilom v okviru prvega stebra EKJUS, je namreč namenjena »klasičnim« tržnim ukrepom, ki spodbujajo rastlinsko proizvodnjo in živinorejo v smislu intenzifikacije in specializacije (89 \% leta 2002). Dejansko ta plačila prispevajo k še večjim kmetijskim pritiskom predvsem na območjih koncentracije intenzivne kmetijske pridelave.

Raziskava okoljske naravnanosti kmetijskega fonda v državah EU-15 (Ribbe, 2002) je opozorila na glavne pomanjkljivosti že reformirane SKP. Dejstvo je, da večji del kmetijskega proračuna, ki predstavlja skoraj 50 \% vseh EU sredstev, še vedno ni povezan z okoljskimi investicijami. Ker dejansko govorimo o kmetijskem sektorju je razumljivo, da bo ta primarno podpiral kmetijsko proizvodnjo. Ob upoštevanju trajnostnega razvoja pa takšne 
politike ni mogoče izvajati na račun okolja. Tudi v kmetijstvu se, podobno kot pri drugih dejavnostih, vse pogosteje in glasneje govori o »stranskih učinkih" oziroma eksternih stroških, ki trenutno $\mathrm{v}$ kmetijski proizvodnji še niso zajeti $\mathrm{v}$ ceno, vendar gredo na račun zmanjšanja zalog in blaginje nekoga drugega. Med temi eksternimi stroški kmetijstva se najpogosteje izpostavlja zmanjšanje zalog neobnovljivih naravnih virov, izgubo biotske raznovrstnosti, vpliv na »zdravje celotne družbe«, stroške preventivnih ukrepov in stroške ponovne vzpostavitve naravnega stanja, ki je posledica kmetijske degradacije (Merrington s sodelavci, 2002).

Obsežne primerjalne analize so pokazale, da t. im. okoljski ukrepi znotraj drugega stebra niso primerno oblikovani in usmerjeni, da bi zmogli kompenzirati vse negativne okoljske učinke kmetijstva, ki so posredno spodbujeni s financiranjem prvega stebra. Tako se v kmetijstvu še vedno nadaljuje prostorska koncentracija, specializacija in intenzifikacija in s tem negativni vplivi kmetijstva na okolje.

Za delitev sredstev znotraj kmetijskega sektorja je značilno, da je v porastu delež sredstev, ki je namenjen neposrednim izplačilom kmetom. Ta plačila danes predstavljajo več kot polovico vseh izdatkov kmetijskega sektorja, so pa predvsem omejena na tiste pridelke, ki so bili do leta 1992 pod "cenovno izravnavo". Tako so travniki in različne krmne rastline (ne koruza), ki so okoljsko pomembni, izpadli iz teh plačil in v številnih evropskih državah smo bili v devetdesetih letih 20. stoletja priče velikemu upadanju travinja (v Nemčiji za $25 \%$ v 20 -ih letih).

Okoljsko slabo naravnanost kmetijskih izplačil kaže tudi razporeditev sredstev znotraj prvega stebra financiranja, kjer je kar $61 \%$ sredstev namenjenih rastlinski pridelavi (pretežno poljskim kulturam). Zaradi močnega. »koruznega lobija« jim je leta 1992 uspelo uvrstiti med pridelke, ki so upravičeni neposrednih plačil, tudi koruzo. Pridelava koruze je ena izmed okoljsko najbolj spornih, saj predstavlja energetsko in snovno izjemno potratno pridelavo (visoka potreba po hranilih, uporaba fitofarmacevtskih pripravkov). Najpomembnejše spremembe $v$ okoljsko trajnostno naravnano financiranje SKP bi torej pomenile spremembe na področju financiranja rastlinske in živalske proizvodnje v okviru prvega stebra, kar bi pomenilo preventiven ukrep z vidika nadaljevanja kmetijskih okoljskih pritiskov.

Plačila drugega stebra SKP, namenjenega razvoju podeželja, so leta 2002 predstavljala komaj $10,3 \%$ vseh sredstev. Z vidika okolja ta plačila niso sporna (za razliko plačil ukrepov znotraj prvega stebra), saj je povezava med okoljskimi koristmi in ohranjanjem narave jasna. Vendar tudi ukrepi, ki se izvajajo znotraj drugega stebra niso v celoti v skladu z okoljskimi zahtevami. Približno polovica sredstev je neposredno namenjenih kmetijsko okoljskim programom, ki jih je samo znotraj EU-15 160, saj so posamezne države oblikovale vrsto regionalnih kmetijsko okoljskih programov. V Sloveniji imamo oblikovan enoten program za celotno območje slovenskega podeželja. Kmetijsko okoljski programi so usmerjeni $\mathrm{v}$ ohranjanje ekstenzivne proizvodnje $\mathrm{v}$ različnih podeželskih problemskih območjih/ regijah, vendar gre praviloma za območja, kjer $\mathrm{v}$ kmetijstvu niso prisotni trendi intenzifikacije, koncentracije in specializacije (območja, ki so naravno najugodnejša za kmetijsko dejavnost). Torej omenjeni ukrepi pravzaprav ne dosegajo glavnega cilja - ekstenzifikacije kmetijske proizvodnje in predvsem zmanjševanje kmetijskih pritiskov na okolje, saj je analiza na območju EU-15 pokazala, da so območja dejanskih sprememb intenzivnejše rabe v ekstenzivnejše skorajda zanemarljiva. 
Struktura izvajanja ukrepov znotraj drugega stebra v posameznih državah EU je zelo različna. Pregled stanja po posameznih državah kaže, da tiste države članice in kmetje, za katere je značilno prevladujoče intenzivno in okoljsko sporno kmetijstvo (npr. Nizozemska, Belgija, posamezna kmetijsko rodovitna območja Nemčije, Francije itd.), v razmeroma skromnem obsegu izvajajo ukrepe drugega stebra sklada (in s tem tudi delež sredstev), medtem ko so se posamezne države članice, kot npr. Avstrija in Finska, ki zaradi naravnih omejitvenih dejavnikov predstavljajo pridelovalno šibke članice, usmerile predvsem v izvajanje ukrepov in koriščenje sredstev tega dela jamstvenega sklada. Glede na vsebinsko zelo raznolik in bogat nabor ukrepov v okviru izvajanja Razvoja podeželja, ki so sicer okoljsko vsi ustrezni, pa je marsikatera država, npr. Grčija, sicer namenoma velik del sredstev koristila s tega programa, vendar ne s področja okoljskih ukrepov temveč v okviru programa zgodnjega upokojevanja, ki dejansko nima nobene neposredne povezave z izboljšanjem stanja v okolju. Na drugi strani v Španiji izvajajo ukrep ogozdovanja, ki pa lahko marsikje pripelje do konfliktnih razmer na območjih varovanja narave.

Hiter pregled programov in ukrepov, ki jih izvaja SKP v zadnjih letih tako kaže, da so podpore prvega stebra okoljsko izrazito neustrezno naravnane, hkrati pa evropski kmetijski sklad tudi sredstev drugega stebra marsikje ne usmerja v strateške ukrepe, ki bi omogočili reševanje številnih okoljskih problemov, ki izvirajo iz kmetijstva. Raziskava okoljsko ustrezne naravnanosti evropskih sredstev za kmetijstvo (Ribbe, 2002) opozarja na pomembne razlike med prvim in drugim stebrom sklada. Ključnega pomena je izrazito neokoljska naravnanost porabe sredstev znotraj prvega stebra (visoke podpore rastlinski in živalski proizvodnji) ter premalo usmerjena politika izvajanja strukturnih ukrepov drugega stebra, kar z vidika bodočega sonaravnega razvoja kliče k novim spremembam v SKP.

\section{Politika razvoja podeželja v Sloveniji danes in v prihodnosti}

Stanje na področju kmetijstva se v Sloveniji v zadnjih letih izjemno hitro spreminja. Z vstopom v EU je bila prav na področju kmetijstva uvedena vrsta zakonodajnih sprememb, vzporedno pa na stanje $\mathrm{v}$ kmetijstvu vplivajo tudi spremembe v prostorskem razvoju (in zakonodaji) ter na okoljskem področju.

Na dolgoročno usmeritev kmetijstva v kontekstu sonaravnega razvoja podeželja ključno vpliva usmeritev politike razvoja podeželja. Trenutno smo sredi obdobja izvajanja Programa razvoja podeželja 2001-2006, hkrati pa je Evropska komisija že oblikovala predlog za drugo programsko obdobje 2007-2013. Slovenija kot nova članica EU je ukrepe v okviru Programa razvoja podeželja uvajala postopoma. Z vidika okolja vsebinsko najpomembnejši del programa predstavljajo ukrepi SKOP-a, za bodoči razvoj pa sta predvsem pomembna vsebina in obseg izvajanja ukrepov v prihodnjem programskem obdobju.

Program neposrednih plačil na enoto kmetijskega zemljišča pomeni bistveno spremembo v delovanju slovenske kmetijske politike, ki je s podpiranjem ohranjanja poseljenosti in kulturne pokrajine, uvajanjem tradicionalnih in sonaravnih oblik kmetovanja ter varovanjem zavarovanih območij dejansko poudarila večnamenskost kmetijstva. Ukrepi kmetijske politike niso več zgolj ozko proizvodno usmerjeni, kot v preteklosti, ampak upoštevajo tudi druge, širše vidike v razvoju podeželja. Istočasno reforma SKP na področju neposred- 
nih plačil z uvedbo enotnega plačila na kmetijsko gospodarstvo vpliva na ekonomsko zanimivost posameznih dejavnosti kmetijstva.

Graf 2: Shema politike razvoja podeželja za obdobje 2001-2006

Figure 2: The scheme of rural development policy for the 2001-2006 period

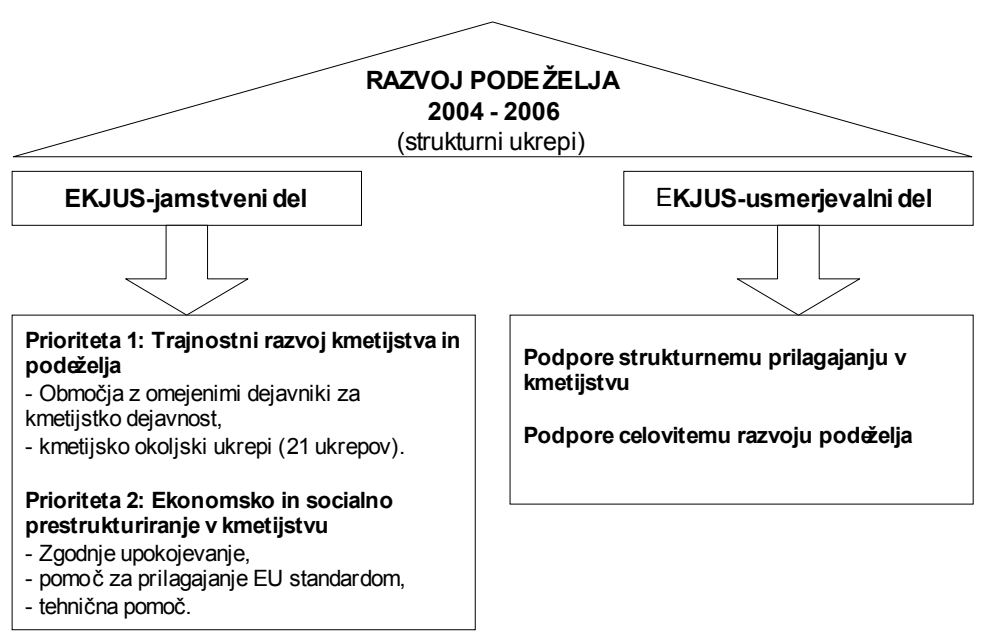

Graf 3: Shema politike razvoja podeželja za obdobje 2007-2013

Figure 3: The scheme of rural development policy for the 2007-2013 period

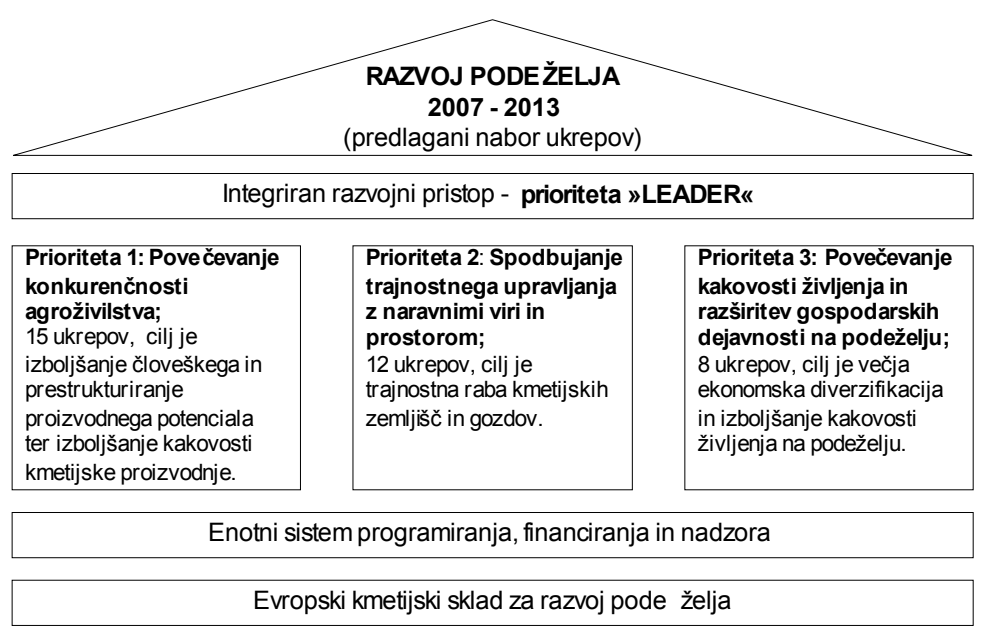

V novem programskem obdobju (2007-2013) bo sklad za razvoj podeželja financiral štiri prednostne osi oziroma prioritete. Program Leader, ki predstavlja horizontalno prioriteto, 
omogoča lokalnim razvojnim partnerstvom večjo samoiniciativnost pri opredeljevanju svoje razvojne strategije znotraj katerekoli prednostne osi razvoja podeželja. Večja bo tudi njihova samostojnost pri odločanju, kateri projekti bodo deležni podpor, del sredstev pa bo namenjen tudi medsebojni izmenjavi izkušenj in povezovanju. Tovrstne vzpodbude lokalnih skupnosti so bile v preteklem desetletju ločene od preostalih ukrepov razvoja podeželja $\mathrm{v}$ okviru samostojne pobude skupnosti Leader. Ker pa se je ta program izkazal za uspešnega, bo njegova vloga v novem programskem obdobju pravzaprav ključna. V vseh treh prednostnih oseh politike razvoja podeželja, konkurenčnosti, varovanju okolja s podporo upravljanju z zemljišči in kakovosti življenja, bo možno izvajati ukrepe po iniciativi Leader (Erhart, Juvančič, 2005).

Potreba po decentralizaciji odločanja in uvajanju pobud s strani lokalnih ravni se je pokazala že pri politikah regionalnega razvoja. V Sloveniji neposrednih izkušenj izvajanja programa Leader še nimamo, imamo pa druge izkušnje glede spodbujanja razvojnega pristopa od spodaj navzgor in spodbujanja lokalnih skupnosti. Načrtovanje razvoja na podlagi lokalnih razvojnih pobud je predstavljal že program CRPOV, katerega so postopoma nadomestile spodbude za pripravo regionalnih programov podeželja (RPP), v katere se po načelu partnerstva združujejo skupine občin s podobnimi razvojnimi možnostmi in interesi. Obstoječi regionalni programi podeželja so usmerjeni predvsem v razvoj turizma na podeželju (podobno kot je bila večina prvih programov Leader v državah EU-15), saj je prav turizem dejavnost, ki omogoča razvoj različnih storitvenih in proizvodnih dejavnosti (Erhart, Juvančič, 2005).

Glede na tuje izkušnje je potrebno izpostaviti tudi največje ovire pri uresničevanju pobude Leader, med katerimi so izjemno pomembni problemi, ki so povezani s predpisi in zakonodajo, politične in institucionalne ovire, administrativne ovire, nenazadnje pa tudi ovire, ki so povezane s t.im. lokalnim socialnim kapitalom (Erhart, Juvančič, 2005). Največ jih je povezanih prav s predpisi in zakonodajo, predvsem s strogimi predpisi pri uporabi sredstev iz strukturnih skladov in pri zagotavljanju lastnih sredstev za financiranje projektov. Glede na izrazito majhne, marsikje demografsko osiromašene in socioekonomsko šibke lokalne skupnosti je pričakovati, da se bomo s tovrstnimi problemi srečali tudi pri nas. Kot se je pokazalo v evropskih državah, velik problem predstavlja tudi povezovanje tako na ravni lokalnih skupnosti kot medregijsko sodelovanje. Opozoriti velja še na rezultate obsežne terenske raziskave izbranih območij slovenskega podeželja (Terensko delo FF, Oddelek za geografijo, 2004-2005), kjer je izvedena anketa med prebivalstvom nakazala velik problem nezainteresiranosti lokalnega prebivalstva za uvajanje novih dejavnosti in izkoriščanja novih razvojnih možnosti. Ravno na tem področju je ob novi usmerjenosti politike razvoja podeželja potrebno predhodno pričeti uvajati ustrezne mehanizme, ki bodo omogočili uspešno izvajanje novega koncepta razvoja podeželja.

\section{Program razvoja podeželja z vidika prostorskih in okoljskih učinkov}

Program razvoja podeželja želi z naborom ukrepov za obdobje 2004 - 2006 slediti dvema prioritetama, in sicer: 
1. sonaravnemu/trajnostnemu razvoju podeželja in kmetijstva; z izravnalnimi plačili za območja z omejenimi možnostmi za kmetijsko dejavnost (OMD) in izvajanjem kmetijsko okoljskih ukrepov (SKOP),

2. ekonomskemu in socialnemu prestrukturiranju kmetijstva; z ukrepom zgodnjega upokojevanja, podporo za prilagoditev kmetijskih gospodarstev EU standardom in tehnično pomočjo (organizacija in izvedba izobraževalnih programov).

Vsi ukrepi PRP se financirajo iz domačih proračunskih sredstev in sredstev jamstvenega sklada oddelka EKJUS v razmerju $20: 80$, skupna vrednost za plačilo teh ukrepov pa je približno 300 mio $€$ in zapadejo v plačilo postopoma leta 2004, 2005 in 2006.

Izvajanje ukrepov v okviru PRP pa ima zaradi samega obsega in raznovrstnosti širše učinke. $\mathrm{K}$ trajnostnemu razvoju podeželja in kmetijstva neposredno največ prispevajo izravnalna plačila za območja z omejenimi možnostmi za kmetijstvo in izvajanje ukrepov SKOP-a.

Izravnalna plačila pomembno prispevajo $\mathrm{k}$ dohodku kmetov na območjih $\mathrm{z}$ omejenimi možnostmi za kmetijsko dejavnost in območjih z okoljskimi omejitvami. Gre za celovit ukrep, ki prispeva $\mathrm{k}$ nadaljnji rabi kmetijskih zemljišč in ohranjanju vaških skupnosti, ohranjanju podeželja, ohranjanju in spodbujanju sonaravnih sistemov kmetovanja (okoljska funkcija) ter zagotavljanju kmetovanja na območjih s posebnimi omejitvami. Poudariti je potrebno tudi pozitiven socialni vpliv, saj ohranja poseljenosti na območjih z nizko gostoto prebivalstva. Ko so se leta 2004 slovenski predpisi uskladiti z evropskim pravnim redom, je prišlo do ostrejših kriterijev pri opredelitvi teh območij. V letu 2003 je bilo še skoraj 88 \% celotne površine Slovenije vključene v seznam območij z omejenimi možnostmi, po novi opredelitvi pa je opredeljenih le še 85 \% vseh površin. Zmanjšal se je tudi del kmetijskih zemljišč, in sicer s 78,2 \% na 73,9 \%, iz območij z omejenimi možnostmi pa je po ocenah MKGP izpadlo okrog 2000 kmetij. Višina izravnalnega plačila v okviru območij z omejenimi možnostmi se izplačuje za hribovska in gorska območje, druga območja ter območja s posebnimi omejitvami in sicer do največ $185 € /$ ha za gorsko višinska območja. Največji delež sredstev pri nas odpade na gorsko-višinske kmetije, sledijo pa jim kmečka gospodarstva na kraških in strmih območjih.

Vrednotenje okoljske naravnanosti kmetijske politike se dejansko najbolj odraža v zastopanosti kmetijsko okoljskih ukrepov, katerih izvajanje pozitivno vpliva na okolje, tako z zmanjševanjem negativnih učinkov kmetijstva na okolje kot tudi z vzdrževanjem obstoječega stanja v okolju/pokrajini. Glavni namen te skupine ukrepov (v letu 2004 in 2005 jih v Sloveniji izvajamo 21) je dolgoročno izboljšanje stanja naravnih virov v Sloveniji. Kmetijsko okoljska plačila so v prvi vrsti namenjena delnemu kritju stroškov dodatnega dela zaradi izpolnjevanja posebnih zahtev pri izvajanju posameznega ukrepa. Vendar ima izvajanje ukrepov SKOP-a tudi druge pozitivne učinke, saj vpliva na dvig izobrazbene ravni in usposobljenosti za izvajanje sonaravnih načinov kmetovanja.

Podpora za prilagoditev kmetij standardom EU in ukrep zgodnjega upokojevanja služita v največji meri ekonomsko-socialnemu razvoju kmetijstva in podeželja. Izvajanje standardov EU ima tudi pomemben pozitiven okoljski vpliv.

Z vstopom v EU se morajo slovenske kmetije soočiti z novimi standardi, ki jih določajo evropski predpisi. Ukrep ima predvsem pozitiven vpliv na okolje, prispeva pa tudi $\mathrm{k}$ 
izboljšanju ekonomskega položaja kmetijskih gospodarstev, ki so se odločila za izvajanje zahtevnih in dražjih EU standardov. Glavni cilj ukrepa je nameniti pomoč kmetom za izvajanje oz. prilagajanje kmetijskih gospodarstev standardom na področju varstva okolja, zdravja rastlin ter varstva pri delu.

Zgodnje upokojevanje $\mathrm{v}$ največji meri vpliva na izboljšanje starostne strukture na kmetijah. Mesečna renta, ki se izplača prenosnikom (kmetom ki se upokojijo), hkrati vpliva na boljši ekonomski položaj kmetijskih gospodarstev, ki so vključena v ta ukrep. Z mehanizmom "pravočasne« upokojitve gospodarjev se poveča tudi dinamika na kmetiji, mlajši, pogosto bolje izobraženi gospodarji pa so nosilci sprememb in uvajanja novosti, tako da ima ta ukrep širši, posredno pa tudi okoljski učinek.

\section{Povezanost kmetijske in okoljske zakonodaje}

Zakon o kmetijstvu (Zkme, 2000) in Slovenski kmetijsko okoljski program (v okviru Programa razvoja podeželja) na področju kmetijstva pomenita ne le preobrat v vlogi kmetijske dejavnosti ampak tudi novo razumevanje odnosa med kmetijstvom in okoljem.

Po letu 1990 je prišlo do sprememb na obeh področjih. Kmetijstvo ni več le proizvodno usmerjena dejavnost, hkrati pa se posledice dolgoletnega intenziviranja in specializacije kmetijstva marsikje že močno odražajo v okolju. Predvsem slabšanje kakovosti naravnih virov (zalog pitne vode, rodovitnosti prsti, biotske pestrosti itd.) je opozorilo na potreben preobrat pri usmerjanju kmetijstva.

Vzporedno se je na področju ugotavljanja okoljskega obremenjevanja pričelo identificirati glavne vzroke, med katerimi ima pomembno mesto tudi kmetijstvo.

Na kvaliteto naravnega okolja imajo številne zakonodajne spremembe $\mathrm{v}$ kmetijstvu vpliv predvsem pri omejevanju vzrokov obremenjevanj, okoljska zakonodaja pa dejansko ukrepa tako na področju nadzora nad kmetijskimi emisijami (preventiva) kot tudi na področju obstoječih onesnaženj (kurativno).

$Z$ vidika varovanja okolja pred pritiski kmetijske dejavnosti je ključnega pomena Operativni program za varstvo voda pred onesnaženjem z nitrati iz kmetijske proizvodnje (za obdobje 2004 do 2008), katerega osnovni cilj je zmanjšanje onesnaženja in preprečevanja onesnaževanja voda z nitrati iz kmetijske proizvodnje. Ta cilj je že opredeljen v nekaterih strateških dokumentih in predpisih na področju varstva okolja in kmetijstva v Sloveniji ter številnih direktivah in uredbah EU.

Nacionalni program varstva okolja (NPVO, 1999), ki določa ključne okoljske cilje in prednostne naloge, ki temeljijo na oceni stanja okolja in prevladujočih trendov, je v okviru prednostnih nalog s področja izboljšanja stanja vodnega okolja kot cilj opredelil zmanjšanje emisij iz razpršenih virov (kamor sodi tudi kmetijstvo). Dejansko to pomeni manj intenzivno kmetijsko proizvodnjo oz. manj snovnih vnosov v obliki organskih in mineralnih gnojil v kmetijstvu. Ukrep, ki ga NPVO predvideva za uresničevanje tega cilja, je priprava programa ukrepov za zaustavitev onesnaževanja podzemnih voda z nitrati, zmanjšanje uporabe mineralnih gnojil in uveljavljanje ekološkega kmetovanja. 


\section{KMETIJSTVO IN OKOLJE V SLOVENIJI}

Gospodarski pomen kmetijstva v državah EU in Sloveniji še vedno upada. Zmanjševanju njegove gospodarske vloge se pripisuje tudi zmanjševanje gospodarske in družbene vloge podeželja nasploh (Kovačič, 1995). V strukturi bruto domačega proizvoda je delež kmetijstva, gozdarstva in ribištva od leta 2003 dalje nižji od $3 \%$ in po napovedih se po še zniževal (UMAR, 2003).

$\mathrm{Z}$ odkrivanjem novih potencialov podeželja v sedemdesetih letih 20 . stoletja so se pričele oblikovati številne politike in programi za pospešen in celovit razvoj podeželskih območij (Kovačič, 1995), s tem pa je kmetijstvo dobilo bistveno širši pomen. Poleg nekdaj osnovne in edine priznane pridelovalne oz. gospodarske funkcije, so kmetijstvu začeli pripisovati tudi socialno, prostorsko-poselitveno, ekološko in kulturno vlogo (Cunder, 1998).

Oznaka naravnih razmer in slovenskega kmetijstva je nasploh precej neugodna. Najpogosteje se izpostavlja majhen delež kmetijske zemlje (v primerjavi s skupno površino) in neugoden relief, kar vse vpliva na manjšo proizvodno sposobnost, ožji izbor kultur in s tem manjšo prilagodljivost ter dražjo pridelavo. Neugodna je tudi velikostna struktura kmetij, kar ima za posledico manjšo storilnost in razmeroma velik delež mešanih kmetij.

Nesporno dejstvo je, da so se razmere v slovenskem kmetijstvu v zadnjih petnajstih letih temeljito spremenile. Obseg kmetijskih površin v uporabi zadnja leta ostaja približno na isti ravni in tako s približno 172.000 ha njiv ( $\mathrm{z}$ manj kot 0,09 ha na prebivalca) ostajamo ena izmed kmetijsko najbolj ekstenzivnih držav v Evropi.

Kljub majhnim spremembam v rabi pa smo priče velikim spremembam v številu in velikosti kmetijskih gospodarstev. Ob Kmetijskem popisu leta 2000 jih je bilo v Sloveniji še 86.467, tri leta kasneje pa se je njihovo število zmanjšalo na 77.149 (Statistični letopis, 2004). Absolutno je upadlo število vseh kmetij z manj kot 10 ha kmetijskih zemljišč v uporabi (KZU), relativno pa se je zmanjšal delež kmetij z manj kot 3 ha KZU. Upoštevajoč velikost kmetij, se je najbolj zmanjšalo število najmanjših kmetij, in sicer tistih z manj kot 5 ha KZU (z 53.384 na 44.372). Za nekaj več kot 2000 kmetij je upadalo tudi število kmetij, velikih od 5 do 10 ha, vendar se je delež teh kmetij v celoti leta 2003 nekoliko povečal. Kmetije tega velikostnega razreda tudi obdelujejo največ kmetijske zemlje v Sloveniji (skoraj 150.000 ha). Po podatkih statistike se tudi število živine med letoma 2000 in 2003 skoraj ni spremenilo (okrog 475.000 GVŽ). Tudi delež kmetij brez živine se ni spremenil in ostaja pri slabih $11 \%$. Pomembno pa je naraslo povprečno število živine na kmetijsko gospodarstvo z živino, in sicer z 6,2 GVŽ na 6,9 GVŽ, po drugi strani pa se je zmanjšal delež kmetij z manj kot $10 \mathrm{GVŽ.} \mathrm{Ti} \mathrm{podatki} \mathrm{že} \mathrm{kažejo} \mathrm{na} \mathrm{razmeroma} \mathrm{hitro} \mathrm{specializacijo}$ živinorejskih kmetij, kar dodatno potrjuje tudi podatek, da se vedno večje število živine redi na kmetijah, večjih od 20 ha. Tako je bilo leta 2000 na takih kmetijah vzrejenih $35 \%$ vseh GVŽ, leta 2003 pa že $41 \%$.

Spremembam v številu in velikosti kmetij sledijo tudi spremembe v kmetijski usmeritvi. Za našo državo tako značilne mešane, poljedelsko-živinorejske kmetije izginjajo, število usmerjenih in specializiranih pa narašča.

Hitre spremembe v slovenskem kmetijstvu potrjujejo tudi številne terenske raziskave. $\mathrm{V}$ zadnjem obdobju so na terenu pridobljeni rezultati pokazali naraščanje števila usmerjenih 
kmetij (Terensko delo, Filozofska fakulteta, Oddelek za geografijo, 2003-2005 ${ }^{3}$ ). Za leto 1996 Rejčeva ugotavlja, da na preučevanih območjih v Sloveniji ni izrazite usmerjenosti oziroma specializacije kmetij, saj je bilo kar $52 \%$ kmetij usmerjenih v mešano proizvodnjo, živinorejsko usmerjenih je bilo $35 \%$, delež ostalih pa zanemarljiv. Terenska raziskava Oddelka za geografijo pa je pokazala, da je v mešano proizvodnjo usmerjen že bistveno manjši delež kmetij (dobrih 40 \%), delež živinorejskih (govedorejskih za prirejo mleka in mesa ter prašičerejskih) ostaja približno enako oziroma okrog $40 \%$, povečuje pa se delež izrazito usmerjenih kmetij (v vinogradništvo, rejo prežvekovalcev, rastlinsko pridelavo).

Različni visoko produktivni konvencionalni kmetijski sistemi so večinoma tudi zelo potratni, tako v smislu povečevanja degradiranosti prsti, zmanjšanja njene rodovitnosti, kakovosti voda, biološke pestrosti in obsega ekosistemskih storitev. Ohranjanje visoke kmetijske proizvodnje gre tako na račun zalog in kakovosti različnih naravnih virov, medtem ko so sonaravne oblike kmetovanja, predvsem ekološko kmetijstvo, naravnane v trajnostno rabo vseh ključnih naravnih virov.

\section{Kmetijstvo kot obremenjevalec okolja v Sloveniji}

Odgovori na naraščajoče okoljske probleme povezane s kmetijsko dejavnostjo se kažejo v nizu reform Skupne kmetijske politike, ki si sledijo od leta 1992 in predstavljajo temeljni preobrat odnosa politike kmetijskega sektorja do okolja. Z uvajanjem vrste ukrepov, ki naj bi v večji meri bili predvsem preventivnega značaja, se je pričela temeljita prenova SKP in sicer od podpiranja tržne kmetijske proizvodnje do nepovezanosti podpor s samo proizvodnjo.

V Sloveniji je pomemben preobrat v kmetijski politiki pomenila že Strategija razvoja slovenskega kmetijstva iz leta 1993, vendar smo s skoraj desetletnim zamikom udejanili okoljski del politike v Programu razvoja kmetijstva, živilstva, gozdarstva in ribištva 20002002 (sprejet 1999), ki vsebinsko sledi ciljem SKP.

$\mathrm{Na}$ pomen in obseg kmetijskega obremenjevanja je $\mathrm{v}$ devetdesetih letih 20 . stoletja opozorila tudi slovenska geografska stroka s sistematičnim spremljanjem obsega in intenzivnosti kmetijskega obremenjevanja različnih slovenskih pokrajin (in različnih kmetijskih sistemov). Na podlagi obsežnih podatkov, ki smo jih nadgradili in obogatili z različnimi podatki in terenskim delom v obdobju 2003 do 2005, skušamo prikazati vpliv SKP na slovensko kmetijstvo in nakazati smeri razvoja slovenskega kmetijstva.

$\mathrm{Na}$ osnovi metodologije energetskih ekvivalentov, ki je bila za potrebe ugotavljanja energetske intenzivnosti kmetijstva oblikovana v Veliki Britaniji (Slesser, 1975), je z obširnimi raziskavami intenzivnosti kmetijstva v Sloveniji že leta 1990 pričel Radinja, metodologijo preizkušal in dopolnjeval z lastnimi raziskavami in v okviru številnih diplomskih nalog. Obsežnejši raziskavi stopnje snovne in energetske intenzivnosti slovenskega kmetijs-

\footnotetext{
${ }^{3}$ Terensko delo je potekalo v okviru projekta CRP Konkurenčnost Slovenije 2001-2006 z naslovom Strukturni problemi in razvojni izzivi slovenskega podeželja v evropski razsežnosti. Ker je raziskava potekala na izbranih sondnih območjih predvsem demografsko ogroženega podeželja in območij z omejenimi možnostmi za kmetijstvo, rezultati niso dovolj reprezentativen vzorec za celo Sloveniji, pomembno pa opozarjajo na trende v kmetijstvu.
} 
tva v različnih slovenskih pokrajinah pa sta bili izvedeni v drugi polovici 90-ih (Rejec Brancelj, 2000; Lampič, 2002).

Tako v Sloveniji prav za obdobje temeljnih sprememb in prestrukturiranja kmetijstva razpolagamo z vrsto podatkov, ki posredno kažejo na stopnjo kmetijskega obremenjevanja kmetijstva, pa tudi na razlike med posameznimi naravnogeografskimi enotami in usmeritvami kmetijstva. Vrednost rezultatov omenjenih raziskav je še toliko večja, saj so bile izvedene v razmeroma kratkem času, so obsežne in metodološko primerljive. Danes je slika kmetijstva precej drugačna, to pa se odraža tudi pri snovno-energetskih agrarnih vnosih in seveda v stopnji kmetijskega obremenjevanja.

Karta 2: Ocena kmetijskega obremenjevanja okolja po prevladujočih kmetijskih sistemih Map 2: The evaluation of agricultural pollution of the environment in agricultural systems

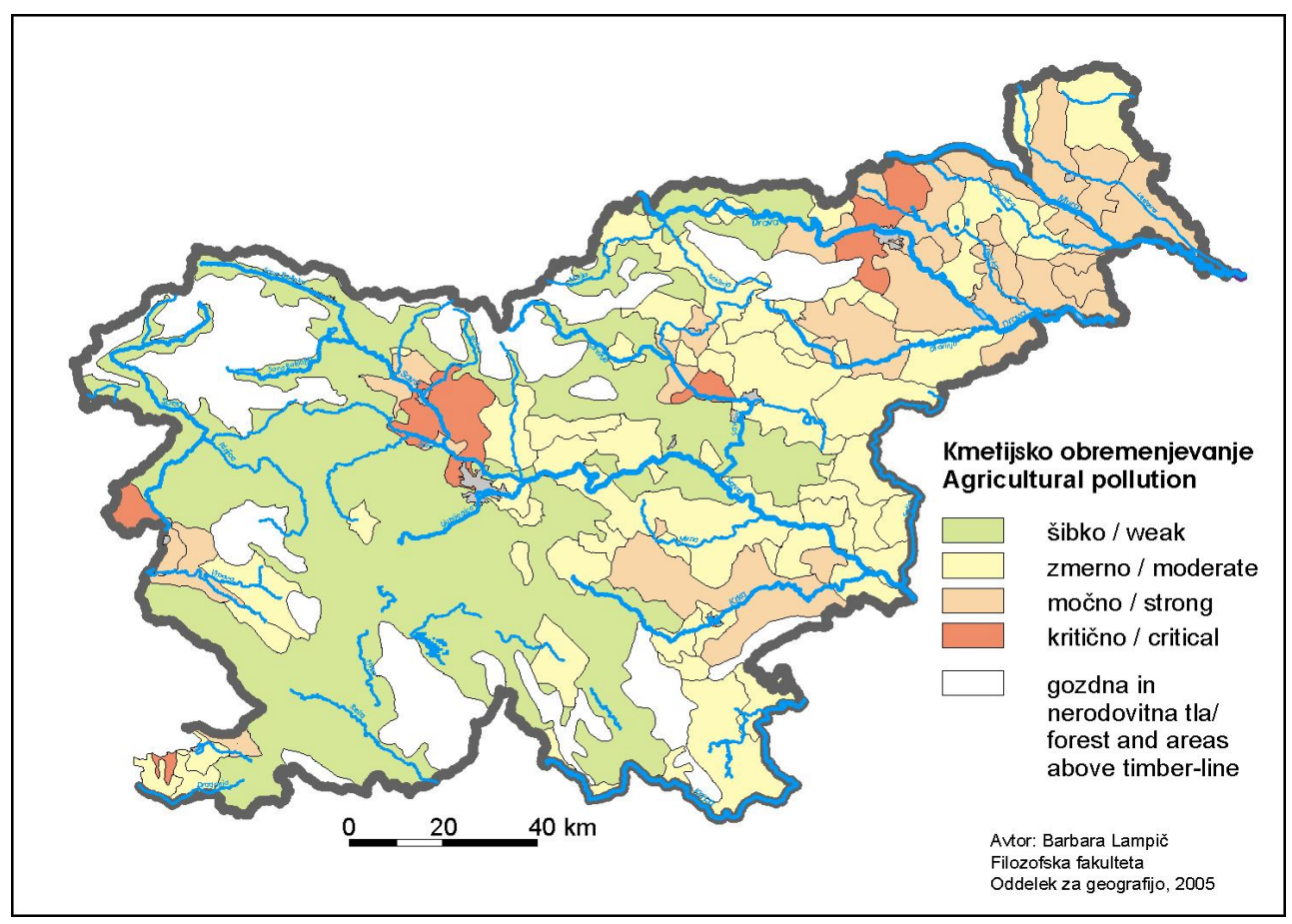

Vir: Lampič, 2000.

Prostorska predstavitev skupnega kmetijskega obremenjevanja okolja po posameznih kmetijskih sistemih temelji na kvantitativnih podatkih zbranih po sondnih območjih. Izbrani kriteriji obremenjevanja so bili: povprečna poraba mineralnih gnojil $(\mathrm{kg} / \mathrm{ha})$, povprečna poraba sredstev za varstvo rastlin $(\mathrm{kg} / \mathrm{ha})$, povprečna poraba tekočih goriv $(\mathrm{l} / \mathrm{ha})$, povprečen vnos skupnega (organskega in mineralnega) dušika $(\mathrm{kg} / \mathrm{ha})$ in povprečna energetska intenzivnost kmetijstva (GJ/ha). Za vsakega od petih kriterijev so bili opredeljeni razredi od 1 (nizka vrednost) do 4 (visoka vrednost), nato pa matrično določena stopnja skupnega obremenjevanja po posameznem kmetijskem sistemu oziroma podsistemu (Lampič, 2002). 
Glede na prevladujočo rabo tal so rezultati do neke mere pričakovani. Prostorsko najbolj razširjeni izraziti krmni sistem (v večji meri zahodna in južna Slovenija) je z okoljskega vidika najmanj obremenjen, kljub nekoliko višjim vnosom skupnega dušika na račun razširjene živinoreje. Precej drugačne razmere so na območjih omiljenega krmnega sistema, kjer je pridelava intenzivnejša zaradi večjega deleža žit in okopavin, predvsem pa je na račun travinja povečan delež krmnih kultur. Intenzivnejša pridelava zahteva večje vnose mineralnih gnojil in skupnega dušika nasploh, zaradi večjega deleža njiv pa je večja tudi poraba sredstev za varstvo rastlin. Poudariti pa je potrebno, da je krmni pridelovalni sistem $\mathrm{v}$ ravninskih predelih bolj obremenjen kot v hribovitem ali kraškem svetu.

Okoljsko najbolj sporni so vnosi na območjih okopavinskih, žitnih in t. im. posebnih kmetijskih sistemov. Razlike znotraj sistemov so precejšnje predvsem pri okopavinskem in posebnem, na splošno pa so to območja, kjer so snovni agrarni vnosi veliki in posledično je povečano tudi kmetijsko obremenjevanje okolja.

Energetska intenzivnost kmetijstva je eden izmed najbolj sinteznih načinov, kako prikazati kmetijsko obremenjevanje okolja. Skupno energetsko porabo predstavlja neposredna poraba fosilnih goriv in posredna poraba energije iz proizvodnje mineralnih gnojil, sredstev za varstvo rastlin, močnih krmil idr.

S podatki v drugih evropskih državah smo primerjali stopnjo energetske intenzivnosti pri nas, z vidika smotrnosti uvajanja sonaravnih oblik kmetovanja pa smo primerjali tudi energetsko porabo (po posameznih pridelkih) za konvencionalno in ekološko kmetijstvo.

Preglednica 1: Stopnja energetske intenzivnosti kmetijstva

Table 1: The level of agricultural energetic intensity

\begin{tabular}{|c|c|c|c|}
\hline \multirow[b]{2}{*}{ območje } & \multirow{2}{*}{$\begin{array}{l}\text { vrsta kmetijske } \\
\text { pridelave }\end{array}$} & \multicolumn{2}{|c|}{ poraba energije v GJ/ha } \\
\hline & & $\begin{array}{l}\text { konvencionalno } \\
\text { kmetijstvo }\end{array}$ & $\begin{array}{l}\text { ekološko } \\
\text { kmetijstvo }\end{array}$ \\
\hline $\begin{array}{l}\text { Slovenija } \\
\text { (Lampič, 2002) }\end{array}$ & $\begin{array}{c}\text { mešana kmetijska } \\
\text { proidelava }\end{array}$ & $20,3-38$ & - \\
\hline $\begin{array}{l}\text { Slovenija } \\
\text { (Rejec Brancelj, 2001) }\end{array}$ & $\begin{array}{c}\text { mešana kmetijska } \\
\text { proidelava }\end{array}$ & 30,5 & - \\
\hline $\begin{array}{l}\text { Evropa - različne države } \\
\text { (Organic agriculture ..., 2002) }\end{array}$ & $\begin{array}{c}\text { ozimno žito } \\
\text { krompir } \\
\text { mlečna živinoreja }\end{array}$ & $\begin{array}{l}18,3-16,5 \\
19,7-38,2 \\
19,1-22,2 \\
\end{array}$ & $\begin{array}{c}10,8-8,2 \\
13,1-27,5 \\
5,9-17,2 \\
\end{array}$ \\
\hline $\begin{array}{l}\text { Slovenija - Zg. Savinjska dolina } \\
\text { (Terensko delo FF, 2004-2005) }\end{array}$ & $\begin{array}{c}\text { pretežno mlečna } \\
\text { živinoreja }\end{array}$ & 14,7 & 10,1 \\
\hline
\end{tabular}

Vir: Terensko delo, FF, Oddelek za geografijo, 2004-2005, Organic agriculture ..., 2002, Lampič, 2002, Rejec Brancelj, 2001.

\section{SONARAVEN (TRAJNOSTNI) RAZVOJ - PRILOŽNOST KMETIJSTVA?}

V okviru analize okoljske razsežnosti Strategije gospodarskega razvoja Slovenije (20012006) Plut (2004) ugotavlja, da se okoljske usmeritve v prvih letih prepočasi udejanjajo. 
Hkrati ta strateško pomemben dokument $\mathrm{v}$ ospredje postavlja okoljske prioritete šibke sonaravnosti (prednost kurativnih ukrepov). Plut ocenjuje, da bi ohranjanje obstoječega vzorca varstva okolja in okoljske politike tudi v prihodnje dolgoročno zmanjšalo prednosti in razvojne priložnosti Slovenije kot primerjalno bolj uspešne države v prehodu in od tod tudi potreba po ekologizaciji gospodarskih dejavnosti ter sonaravne rabe domačih obnovljivih virov. To vsekakor velja tudi za kmetijstvo. Preusmerjanje intenzivnega kmetijstva v snovno ekstenzivnejše, sonaravne oblike kmetovanja (npr. ekološko kmetijstvo), sodi med t. im. okoljske prioritete močne sonaravnosti, saj gre za ukrep oziroma ukrepe, ki zmanjšujejo oziroma se izogibajo okoljskim pritiskom.

V okviru raziskave na Oddelku za geografijo (Klemenčič M. s sodelavci, 2005), smo na izbranih podeželskih območjih izvajali anketo o razvojnih priložnostih. Pri anketiranju je sodelovalo tako kmečko kot nekmečko prebivalstvo, število anketiranih je bilo skoraj 900, pri vprašalniku zaprtega tipa pa je bilo mogoče dati več odgovorov. Rezultati so pokazali, da prebivalstvo na podeželju, z izjemo nekaterih območij (npr. Murska ravan kot tradicionalno kmetijsko območje), ne vidi več potenciala v razvoju kmetijske dejavnosti. Prihodnost razvoja podeželskega prostora vidijo $\mathrm{v}$ povezavi $\mathrm{z}$ razvojem turizma, povezanega $\mathrm{s}$ kmetijstvom pa tudi širše. Zanimivo je tudi, da je zelo velik delež anketirancev ( $30 \%$ odgovorov) kot razvojno priložnost (svojega območja) izpostavil nove oblike kmetijstva, od reje drobnice, ekološkega načina kmetovanja ipd. Na drugi strani izstopajo posamezna območja (Murska ravan, Haloze, Bela krajina), kjer velik delež prebivalstva (preko $20 \%$ anketirancev posameznega območja) ne vidi nobenih pravih razvojnih možnosti in priložnosti. To kaže na pasivnost prebivalstva hkrati pa poudarja težko, za prebivalstvo včasih celo brezizhodno situacijo, $v$ kateri so se marsikje znašli.

Veliko odgovorov, npr. priložnost z uvajanjem novih oblik kmetovanja, je pogojenih tudi s trenutnimi razmerami v kmetijstvu. Prebivalstvo je ponekod dobro seznanjeno $\mathrm{z}$ razmeroma ugodnimi subvencijami za integrirano in ekološko pridelavo, številni pa se zavedajo, da bi predvsem razvoj turizma oplemenitil in omogočil razvoj tako kmetijstva kot drugih dopolnilnih dejavnosti.

Graf 4: Struktura neposrednih plačil v Sloveniji leta 2004

Figure 4: Direct payments structure in Slovenia in 2004

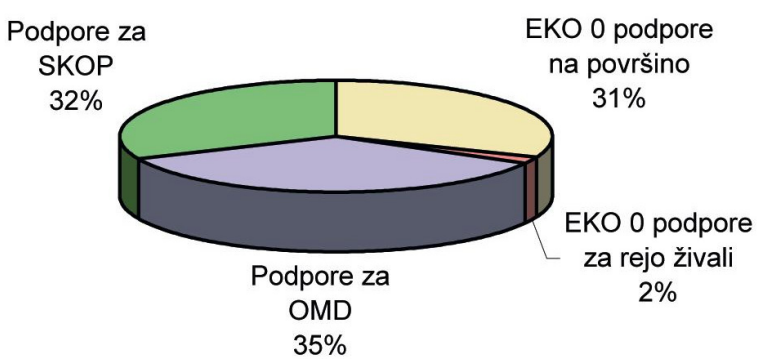

Vir: Agencija RS za kmetijske trge in razvoj podeželja, 2005. 
Neposredna kmetijska plačila so vezana na obdelovalne površine ali GVŽ in ne na pridelek. Po podatkih za leto 2004 so skupne podpore (EKO 0 na površino, EKO 0 za drobnico in čebele, podpore za OMD in podpore za izvajanje ukrepov SKOP) v Sloveniji znašale preko 26,5 mrd SIT, v strukturi plačil pa prevladujejo podpore za območja z omejenimi dejavniki za kmetijstvo.

Gledano z vidika varovanja okolja je najpomembnejši delež sredstev, ki je namenjen izvajanju kmetijsko okoljskih ukrepov. Vendar se struktura neposrednih plačil regionalno pomembno razlikuje, še večje pa so razlike na nivoju občin.

V celoti je absolutna podpora po statističnih regijah najvišja v Pomurski, Podravski, Savinjski in Osrednjeslovenski regiji. Kmetijstvo igra pomembno vlogo v vseh treh regijah severovzhodne Slovenije, zato je višina izplačil razumljiva. Z vidika okoljske naravnanosti neposrednih plačil pa je pomemben predvsem delež, ki je namenjen ukrepom SKOP-a. Če v Sloveniji ta delež predstavlja dobrih $30 \%$, je v vseh omenjenih regijah nižji. Predvsem je visok v regijah vzhodne Slovenije, kjer je delež obdelovalnih kmetijskih zemljišč razmeroma visok, zato je takšen tudi delež neposrednih plačil na površino (KZU). Ta podpora je namenjena in podpira konvencionalno kmetovanje, hkrati pa ima do neke mere tudi pozitiven socialen vpliv.

Karta 3: Struktura neposrednih plačil po statističnih regijah Slovenije leta 2004

Map 3: Direct payments structure by statistical regions of Slovenia in 2004

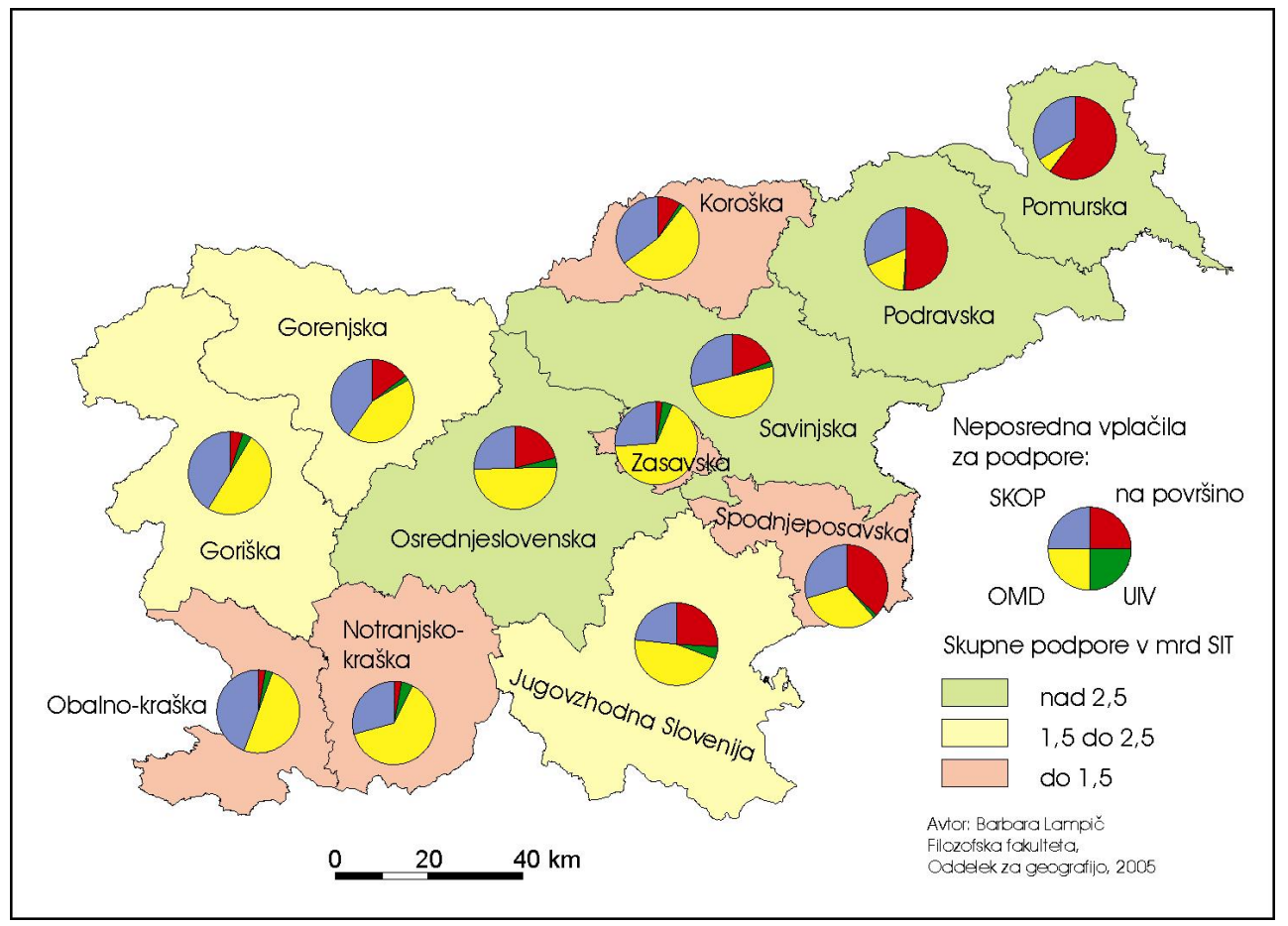

Vir: Agencija RS za kmetijske trge in razvoj podeželja, 2005. 
Celovit ukrep, ki ga predstavljajo izplačila na območjih z omejenimi dejavniki za kmetijstvo (OMD), vpliva tako na vzdrževanje kmetijske rabe in kulturne pokrajine, ohranja poselitev in sonaravne oblike kmetovanja. Najbolj je zastopan v pretežno hribovitih in kraških statističnih regijah, več kot $50 \%$ vseh sredstev pa predstavlja v Koroški, Zasavski, Notranjsko-kraški, Osrednjeslovenski, Goriški in Savinjski regiji.

Razporeditev neposrednih plačil po občinah Slovenije v letu 2004 kaže na pomembne razlike med njenim vzhodnim in zahodnim delom. Poudariti pa velja še en pomemben vidik, in sicer samo višino sredstev, ki v kar 22 občinah presegajo 300 mio SIT. S sredstvi evropskega kmetijskega jamstvenega sklada se tako financira določen delež prebivalstva oziroma dejavnost, ki jo opravljajo.Ti zneski niso majhni v primerjavi z višino občinskih proračunov. Dejstvo je, da neposredna plačila predstavljajo pomemben finančni doprinos, vprašanje pa je, ali so ta sredstva ustrezno ciljno naravnana.

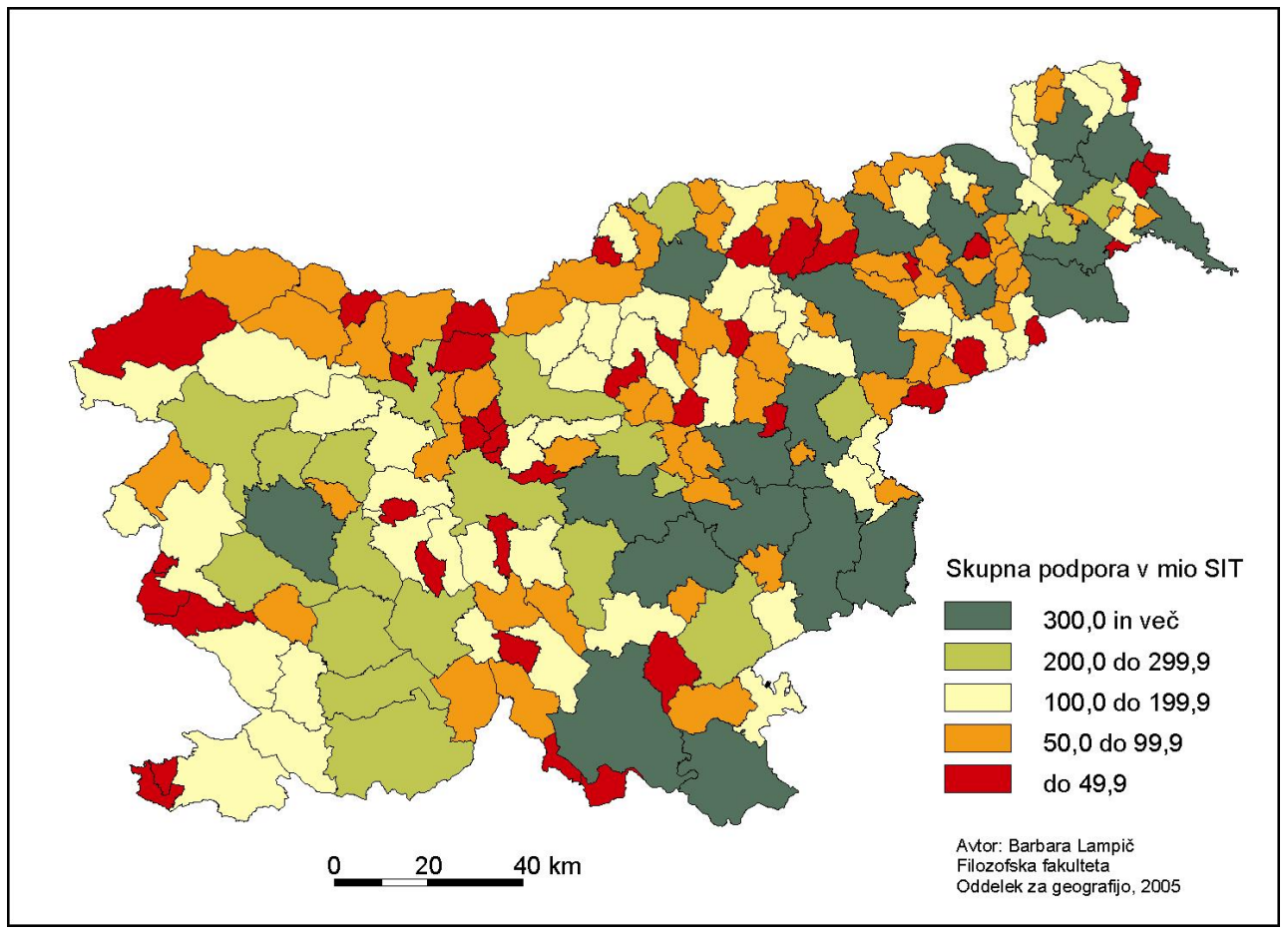

Vir: Agencija RS za kmetijske trge in razvoj podeželja, 2005.

Prostorski prikaz ocene kmetijskega obremenjevanja se dobro ujema s prikazom višine neposrednih plačil na površino in hkrati kaže na usmerjenost kmetijske politike, ki še vedno znaten delež sredstev namenja konvencionalni kmetijski pridelavi, saj so najvišja izplačila na območjih občin, ki imajo visok delež predvsem ornih površin (prevladujejo pridelovalno 
intenzivnejši kmetijski sistemi). Če v povprečju znašajo podpore z neposrednimi plačili v Sloveniji dobrih 55.000 SIT na hektar, je ta znesek presežen v kar 79 občinah.

Karta 5: Podpora z neposrednimi plačili na ha KZU po občinah Slovenije leta 2004

Map 5: Direct payment subsidy per agricultural land in use (ALU) in Slovenian municipalities in 2004

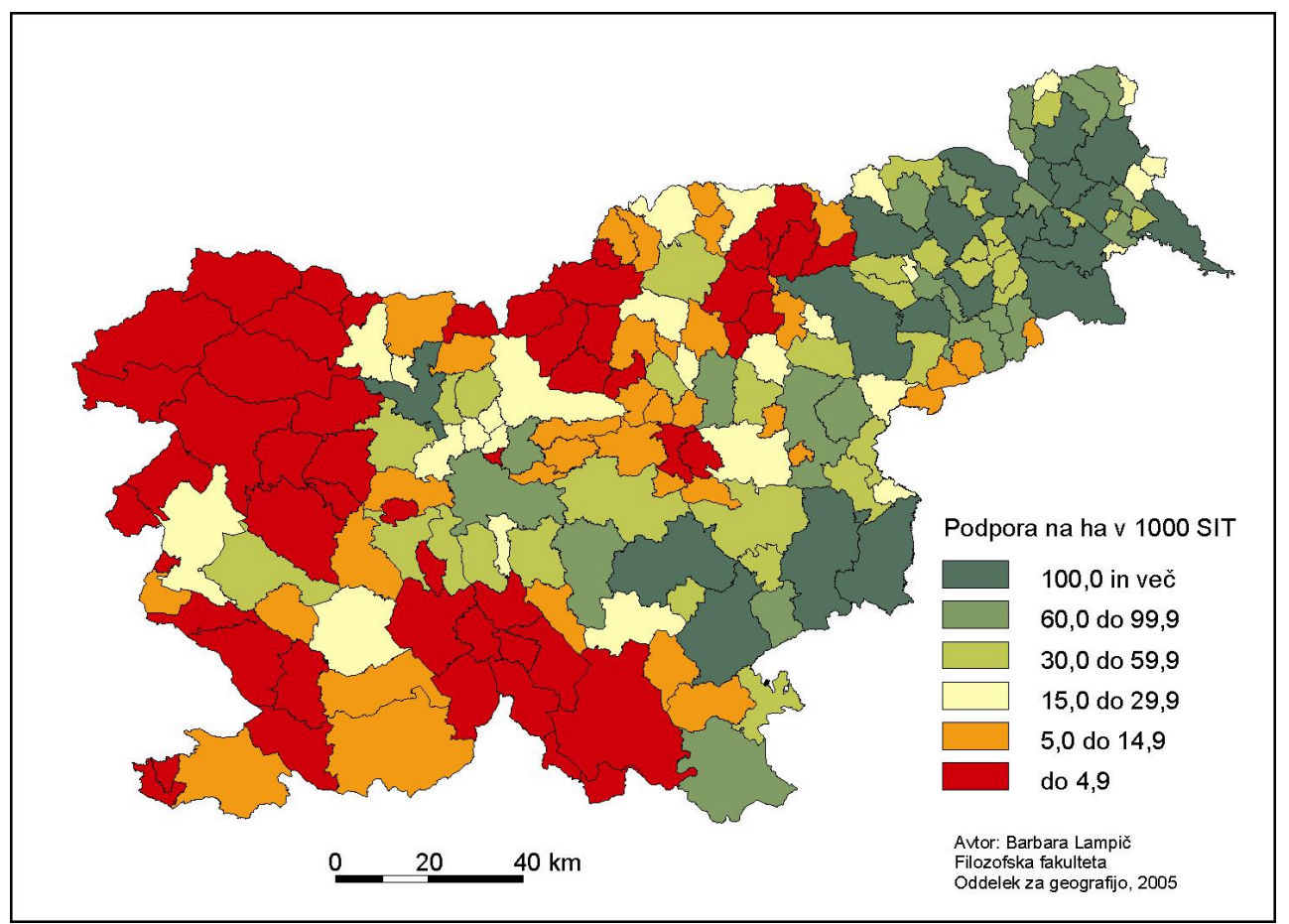

Vir: Agencija RS za kmetijske trge in razvoj podeželja, 2005.

Po podatkih Agencije RS za kmetijske trge in razvoj podeželja (ARSKTRP) je razpon vrednosti neposrednih plačil na hektar kmetijskih zemljišč med občinami velik in znaša od 26.500 SIT pa do nekaj več kot 106.000 SIT, torej kar v razmerju 1:4.

Ker pa se iz skupne vrednosti neposrednih plačil ne zrcali dejanska vloga izrazito okoljskih plačil, smo pod drobnogled vzeli tista, ki so namenjena izvajanju ukrepov SKOP-a.

Celotna razporeditev sredstev po posameznih ukrepih kaže, da je največji delež kmetijsko okoljskega programa namenjen ohranjanju naravnih danosti in biotske pestrosti ter tradicionalne kulturne pokrajine. Skoraj enak delež sredstev (41\%) je namenjen izrazitim okoljskim ukrepom, in sicer zmanjševanju negativnih vplivov kmetijstva na okolje. Gre za skupino sedmih ukrepov, ki predstavljajo podpore ekstenzivnejšim in sonaravnejšim oblikam kmetovanja in so reakcija na že prisotne negativne okoljske vplive kmetijstva. Kar štirje ukrepi so namenjeni podpori integriranih oblik kmetijstva (poljedelstva, vinogradništva, sadjarstva in vrtnarstva), dva ukrepa sta namenjena ohranjanju ekosistemskih funkcij (ohra- 
njanje kolobarja in zmanjševanje erozije v vinogradništvu in sadjarstvu), ukrep za spodbujanje ekološkega kmetovanja pa predstavlja okoljsko najbolj učinkovit in celovit ukrep, vendar po višini plačil, številu vlog in obsegu krepko zaostaja za integriranimi oblikami kmetovanja. Okoljska plačila za ekološko kmetovanje so edini sistemski ukrep kmetijske politike v Sloveniji, ki se nanaša neposredno na sektor ekološkega kmetijstva in živil. Ta plačila so na enoto površine najvišja med kmetijsko okoljskimi plačili za ukrepe SKOP-a, vendar lahko posamezna kmetija s kombinacijo dveh ali treh drugih ukrepov doseže najvišje možno plačilo na hektar. To znaša $600 € /$ ha za njive, kar $900 € /$ ha za trajne nasade, maksimalna vrednost plačila za travinje pa je $450 € /$ ha. Tako se mnoge kmetije raje odločajo za druge kombinacije ukrepov, ki so v smislu naporov in dodatnih stroškov manj zahtevni od ekološkega kmetovanja.

V celoti je bilo za ukrepe SKOP-a v letu 2004 izplačanih 8,3 mrd SIT, kar v povprečju pomeni več kot 200.000 SIT na kmetijsko gospodarstvo.

Graf 5: Struktura plačil znotraj glavnih skupin ukrepov SKOP-a leta 2004

Figure 5: The payments structure within the principal measures of Slovene Agri-Environment Programme in 2004

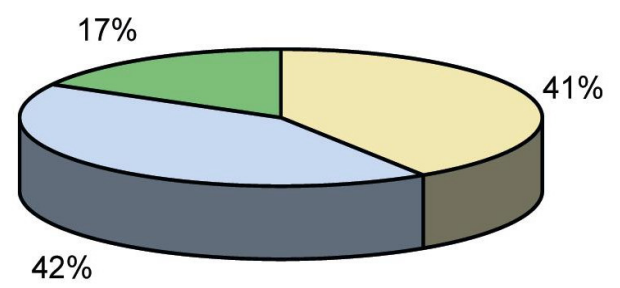

口ukrepi za zmanjševnanje negativnih vplivov kmetijstva na okolje

पukrepi ki spodbujajo ohranjanje naravnih danosti, biotske pestrosti, rodovitnosti tal in tradicionalne kulturne krajine

口ukrepi pomoči varovanja zavarovanih območij

Vir: Agencija RS za kmetijske trge in razvoj podeželja, 2005.

Če pogledamo vrednost plačil po vseh 21 ukrepih, so ta najvišja za ukrep ozelenitev njivskih površin (v skupini ukrepov varovanja zavarovanih območij), sonaravno rejo domačih živali (v skupini ukrepov, ki spodbujajo varovanje naravnih danosti, biotske pestrosti, rodovitnosti tal in tradicionalne kulturne pokrajine) ter integrirano poljedelstvo (v skupini ukrepov za zmanjševanje negativnih vplivov kmetijstva na okolje. Za vse omenjene ukrepe so bila plačila v letu 2004 višja od ene mrd SIT (ARSKTRP, 2005).

Več kot 500 mio SIT je bilo namenjenih še izvajanju ukrepa košnje strmih travnikov, integriranemu vinogradništvu in ekološkemu kmetijstvu. 
Graf 6: Izplačana sredstva po posameznih ukrepih SKOP-a v letu 2004 (v 1000 SIT)

Figure 6: Means paid out by separate measures of Slovene Agri-Environment Programme in 2004 (in 1000 SIT)

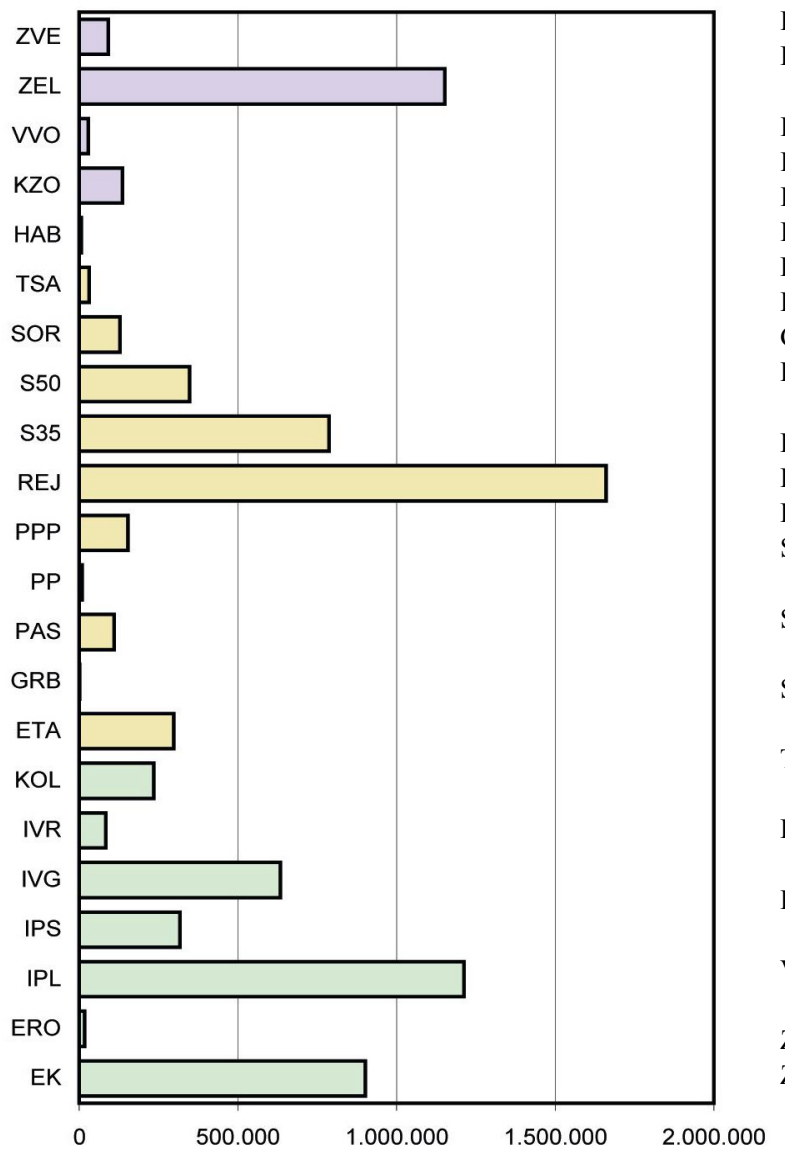

\begin{tabular}{|c|c|}
\hline $\begin{array}{l}\text { EK } \\
\text { ERO }\end{array}$ & zmanjševanje erozije v \\
\hline IPL & $\begin{array}{l}\text { vinogradništvu in sadjarstvu } \\
\text { integrirano poljedelstvo }\end{array}$ \\
\hline & integrirano sadjarstvo \\
\hline G & integrirano vinogradništvo \\
\hline $\mathrm{R}$ & integrirano vrtnarstvo \\
\hline $\mathrm{OL}$ & ohranjanje kolobarja \\
\hline TA & ohranjanje ekstenzivnega travinja \\
\hline RB & košnja grbinastih travnikov \\
\hline AS & $\begin{array}{l}\text { reja avtohtonih in tradicionalnih } \\
\text { pasem domačih živali }\end{array}$ \\
\hline & planinska paša brez pastirja \\
\hline PP & planinska paša s pastirjem \\
\hline & sonaravna reja domačih živali \\
\hline & $\begin{array}{l}\text { košnja strmih travnikov z nagi- } \\
\text { bom } 35^{\circ}\end{array}$ \\
\hline & $\begin{array}{l}\text { košnja strmih travnikov z nagi- } \\
\text { bom } 50^{\circ}\end{array}$ \\
\hline & $\begin{array}{l}\text { pridelava avtohtonih in tradicio- } \\
\text { nalnih sort kmetijskih rastlin }\end{array}$ \\
\hline & travniški sadovnjaki z gostoto \\
\hline & $\begin{array}{l}50-200 \text { dreves na ha } \\
\text { ohranjanje posebnih traviščnih } \\
\text { habitatov }\end{array}$ \\
\hline & $\begin{array}{l}\text { ohranjanje obdelane in poseljene } \\
\text { krajine na zavarovanih območjih }\end{array}$ \\
\hline & $\begin{array}{l}\text { pokritost tal na vodovarstvenih } \\
\text { območjih }\end{array}$ \\
\hline & ozelenitev njivskih površin \\
\hline & $\begin{array}{l}\text { reja domačih živali v osrednjem } \\
\text { območju pojavljanja velikih zveri }\end{array}$ \\
\hline
\end{tabular}

Vir: Agencija RS za kmetijske trge in razvoj podeželja, 2005.

\section{Usmerjanje kmetovanja v sonaravno gospodarjenje $z$ okoljem in trajnostni razvoj}

Obseg izvajanja kmetijsko okoljskih ukrepov skupaj z namenjenimi sredstvi kažejo, da ima usmerjanje v sonaravno kmetijstvo $\mathrm{v}$ okviru programa razvoja podeželja pomembno vlogo.

Od leta 2001, ko smo v Sloveniji pričeli izvajati kmetijsko okoljske ukrepe, so se površine pod ukrepi povečale $\mathrm{z}$ dobrih 98.000 ha na skoraj 280.000 ha v letu 2004 (povečale za trikrat). Največja rast je bila prav v obdobju med letoma 2003 in 2004, ko se je pričelo izvajati vseh 21 ukrepov, saj so se površine pod ukrepi SKOP-a skoraj podvojile. 
Preglednica 2: Izvajanje Slovenskega kmetijskega okoljskega programa od leta 2001 do 2004

Table 2: Implementation of Slovene Agri-Environment Programme from 2001 to 2004

\begin{tabular}{|l|r|r|r|}
\hline leto & $\begin{array}{r}\text { obseg površin } \\
(\mathrm{v} \text { ha) }\end{array}$ & $\begin{array}{r}\text { število odobrenih } \\
\text { vlog }\end{array}$ & $\begin{array}{r}\text { izplačana sredstva } \\
\text { (v mio SIT) }\end{array}$ \\
\hline 2001 & 98.216 & 14.107 & - \\
\hline 2002 & 114.180 & 14.714 & 1686,8 \\
\hline 2003 & 140.864 & 17.171 & 2255,7 \\
\hline 2004 & 277.437 & 39.771 & 8344,1 \\
\hline
\end{tabular}

Vir: Agencija RS za kmetijske trge in razvoj podeželja, 2005.

Še bolj se je $\mathrm{v}$ tem obdobju povečalo število odobrenih vlog za izvajanje omenjenih ukrepov, od 17.171 na skoraj 40.000. Ker se je povečal nabor ukrepov in ker lahko kmetje večino ukrepov med seboj kombinirajo (do dovoljene vrednosti na hektar), ne prihaja do pomembnejšega vključevanja novih kmetov v program, ampak se za izvajanje novega ukrepa odločijo predvsem kmetje, ki že prejemajo podpore za posamezne ukrepe in tako povečajo priliv sredstev na kmetiji. Pri izvajanju omenjenih ukrepov je namreč potrebno poudariti, da morajo kmetje v programu sodelovati vsaj pet let.

Podobno kot se je povečal obseg površin (kjer se izvajajo posamezni ukrepi kmetijsko okoljskega programa) in število odobrenih vlog, so se povečala tudi izplačana sredstva za ukrepe (leta 2004 dosegla 8,3 mrd SIT, leta 2003 pa le 2,3 mrd SIT).

Vsi navedeni kazalci očitno kažejo, da kmetijska politika namenja vse večji poudarek okoljski in varovalni komponenti kmetijstva. Hkrati je potrebno poudariti, da je delež sredstev, ki je v okviru PRP v Sloveniji namenjen za SKOP, v primerjavi z evropskim povprečjem (okrog 55 \% leta 2002) in s številnimi evropskimi državami, še vedno nižji.

$Z$ vidika okoljskih in prostorskih učinkov vseh omenjenih ukrepov je najpomembnejša njihova ustrezna prostorska razporeditev, ki bi morala izhajati iz naravnih značilnosti ter stanja kakovosti ključnih naravnih virov. Glede na temeljne cilje oziroma namen SKOP-a, da poleg varovanja zdravja ljudi popularizira kmetijsko pridelavo, ki je naravnana $v$ trajnostno rabo naravnih virov, ohranjanje biotske raznovrstnosti ter značilne kulturne pokrajine, smo iskali povezavo med izvajanimi ukrepi in tistimi naravnimi viri, ki so za prebivalstvo in trajnostni razvoj strateškega pomena, hkrati pa je dosedanja kmetijska proizvodnja že načela njihove zaloge oziroma kakovost.

Pregled obsega površin pod kmetijsko okoljskimi ukrepi leta 2004 kaže, da je njihov največji obseg na območju Alpske Slovenije; Tolminskega, Škofjeloškega in Cerkljanskega hribovja, na Notranjskem in Kočevskem, v manj pa na širšem območju vzhodne Slovenije. Obseg površin pod ukrepi SKOP-a ni odvisen od površine obdelovalnih zemljišč v občini, saj se lahko posamezni ukrepi na določenem obdelovalnem zemljišču podvajajo (možnost kombiniranja posameznih ukrepov).

Če pa na razporeditev okoljskih ukrepov gledamo z vidika slovenskega strateško najpomembnejšega naravnega vira, torej pitne vode, pa po majhnem obsegu izvajanja ukrepov marsikje izstopajo občine na prodnih ravnicah, kjer so naše največje zaloge podtalnice. Predvsem to velja za območje Dravskega in Ptujskega polja, ki je hkrati eno izmed kmetijsko najintenzivnejših območij, Spodnjo Savinjsko dolino in pomemben del Kranjskega polja. 
Karta 6: Izvajanje kmetijsko okoljskih ukrepov SKOP-a po občinah leta 2004

Map 6: The implementation of agri-environment measures of Slovene Agri-environment Programme (SKOP) by municipalities in 2004

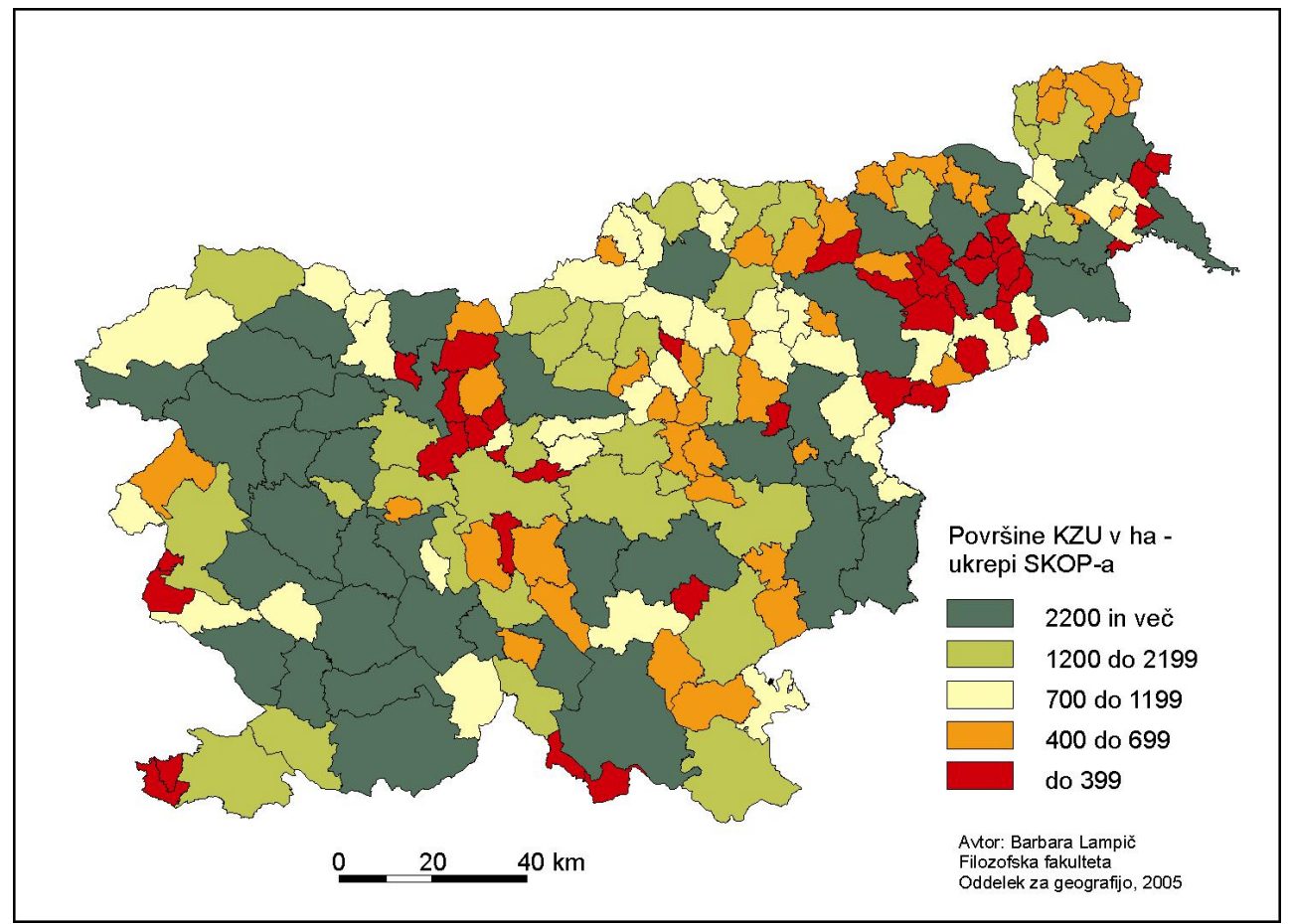

Vir: Agencija RS za kmetijske trge in razvoj podeželja, 2005.

Zelo soroden je prostorski prikaz razmestitve podpor za izvajanje kmetijsko okoljskih ukrepov. Ker pa se podpore na hektar površine za posamezne ukrepe razlikujejo, prihaja do manjših razlik med obsegom ukrepov in podporami na nivoju občin.

Kar 40 slovenskih občin je samo za ukrepe SKOP-a v letu 2004 prejelo več kot 60 mio SIT, 17 občin pa celo več kot 100 mio SIT. Zanimivo je, da so vse občine, ki prejemajo najvišje podpore za izvajanje okoljskih ukrepov, v vzhodnem, za kmetijstvo najugodnejšem in po dosedanjih analizah kmetijsko najintenzivnejšem delu Slovenije. Preko 150 mio SIT podpore za izvajanje kmetijsko okoljskih ukrepov prejmejo kmetje v občinah Krško, Brežice, Maribor, Ptuj, Ljutomer, Ormož, Lendava, Murska Sobota in Gornja Radgona. Takšna slika je z vidika bodočega, sonaravnega kmetijstva zelo ugodna. Vendar pa ob pregledu strukture posameznih ukrepov vidimo, da $\mathrm{v}$ teh, kmetijsko intenzivnih občinah (z izjemo Brežic in Krškega) s preko 50 \% prevladujejo plačila za integrirane oblike kmetijstva, medtem ko je delež ekološkega kmetijstva ali minimalen (do $2 \%$ ) ali pa podpor za ekološko kmetijstvo sploh ni.

Tu je potrebno poudariti ključno razliko med integriranimi oblikami kmetijstva, ki dovoljujejo t. im. nadzorovano uporabo gnojil in fitofarmacevtskih sredstev (v skladu s pravili 
ali smernicami za integrirano pridelavo sadja, zelenjave, itd.) in ekološkim kmetovanjem, kjer je uporaba mineralnih gnojil in sintetičnih fitofarmacevtskih sredstev popolnoma prepovedana.

Drug primer je občina Gorenja vas - Poljane, ki prav tako sodi med tiste, ki prejemajo visoka izplačila za kmetijsko okoljske ukrepe. Vendar v tej, pretežno hriboviti občini, prevladuje delež sredstev, ki je namenjen košnji strmih travnikov in sonaravni reji domačih živali. Glavnina sredstev je torej namenjena ukrepoma, ki sodita v skupino ukrepov za ohranjanje naravnih danosti in tradicionalne kulturne pokrajine.

Karta 7: Podpore za izvajanje kmetijsko okoljskih ukrepov SKOP-a po občinah Slovenije leta 2004

Map 7: Subsidies for agri-environment measures implementation by Slovene municipalities in 2004

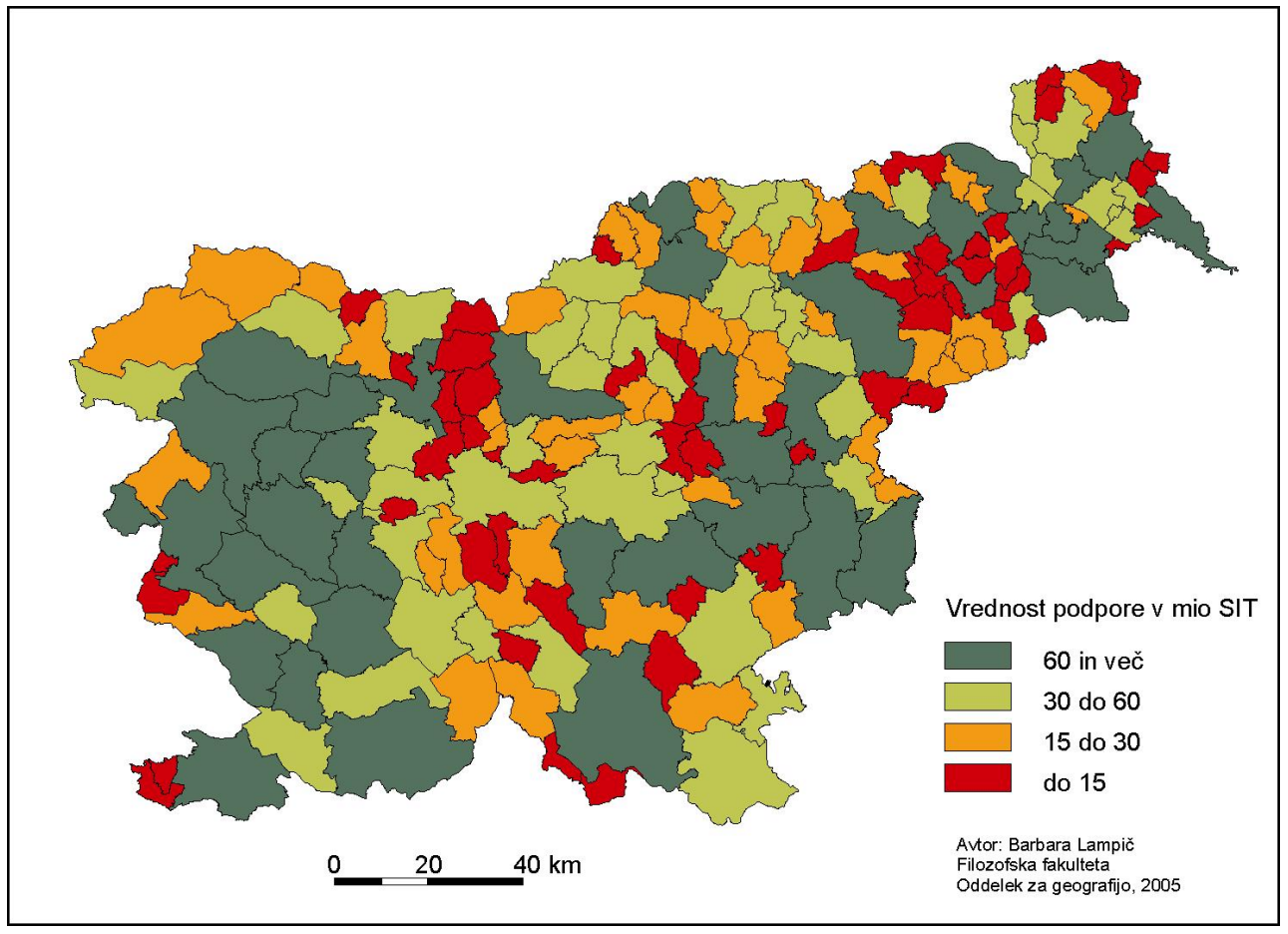

Vir: Agencija RS za kmetijske trge in razvoj podeželja, 2005.

Kratek pregled stanja na področju izvajanja ukrepov prenovljene SKP, predvsem izvajanje ukrepov SKOP-a, s katerim je Slovenija naredila enega najpomembnejših korakov pri usklajevanju slovenskega pravnega reda s pravnim redom EU na področju kmetijstva, kaže na razmeroma hitro uveljavljanje podpor tudi v Sloveniji. Očitne pa so velike regionalne razlike. Že grob pregled kaže, da predvsem ni zaznati neposredne povezave med potrebami in zahtevami naravnega okolja/naravnih virov in aktualne kmetijske obremenjenosti na eni ter 
dejansko zastopanostjo ukrepov in sredstev, ki so namenjeni za ohranitev in izboljšanje naravnih kakovosti naše države.

\section{Vrednotenje učinkov kmetijsko okoljskih ukrepov}

Program razvoja podeželja je $\mathrm{v}$ celoti usmerjen $\mathrm{k}$ trajnostnemu razvoju, največjo okoljsko vlogo pa imajo ukrepi SKOP-a. V okviru izoblikovanega programa (leta 2001) so bili z namenom kontinuiranega spremljanja izvajanja ukrepov, opredeljeni kontrolni (kratkoročni) in dolgoročni kazalniki, s pomočjo katerih naj bi se ocenjevali predvsem učinki kmetijsko okoljskih ukrepov. Žal so ti kazalniki merjenja dokaj enoplastni; število vlog za posamezen ukrep, obseg izvajanega ukrepa $v$ hektarih zemljišč ipd., ni pa bilo predvidenih in oblikovanih kazalnikov, ki bi merili in vrednotili dejanske vplive ukrepov.

Med vsemi ukrepi, ki so se izvajali v letu 2004, je ključnih sedem ukrepov v t. im. skupini ukrepov za zmanjševanje negativnih vplivov kmetijstva na okolje, in sicer ekološko kmetovanje, zmanjševanje erozije v vinogradništvu in sadjarstvu, integrirano poljedelstvo, integrirano sadjarstvo, integrirano vinogradništvo, integrirano vrtnarstvo in ohranjanje kolobarja. Izhodišče vseh omenjenih ukrepov je, da ima intenzivna pridelava hrane na okolje/naravne vire, predvsem zaradi nesmotrne rabe gnojil in sredstev za varstvo rastlin, lahko negativne vplive. Hkrati je nesmotrna pridelava pogosto vzrok eroziji prsti in zbitosti tal, $\mathrm{s}$ tem pa se zmanjšuje rodovitnost prsti.

Gre za skupino ukrepov, katerih učinki so najbolj neposredno povezani tako z zmanjševanjem kmetijskih vnosov, posredno pa seveda $\mathrm{z}$ zmanjševanjem negativnih učinkov kmetovanja. $Z$ uvajanjem snovno ekstenzivnejših oblik kmetijstva, kjer je uporaba okoljsko spornih gnojil in fitofarmacevtskih sredstev bodisi omejena in načrtovana ali pa povsem prepovedana, najbolj pripomoremo $\mathrm{k}$ dejanskemu zmanjševanju vplivov kmetijstva na okoljske sestavine, s tem pa tudi na njihovo obremenjenost. Podpore za ohranjanje kolobarja niso povsem neposredno povezane z zmanjševanjem vplivov kmetijstva na okolje, ker pa ustrezen kolobar bistveno vpliva na lastnosti prsti in njihovo rodovitnost ter pomembno vpliva na naravno ravnovesje $\mathrm{v}$ kmetijskem ekosistemu, je tudi okoljska vloga tega ukrepa nesporna. $V$ času intenzifikacije in želje po kar največji pridelavi se je namenoma zanemarjal ustrezen kolobar, zemlja se je izčrpavala, povečevanje pa se je spodbujalo s povečanjem gnojenja, kar je zopet vodilo v okoljske obremenitve.

Učinki ukrepov, katerih izvajanje je namenjeno ohranjanju naravnih danosti, biotske pestrosti, rodovitnosti tal, tradicionalne kulturne pokrajine in varovanju zavarovanih območij, so manj povezani z neposrednim izboljšanjem stanja $\mathrm{v}$ okolju, imajo pa pomembno vlogo $v$ trajnostnem razvoju podeželja. Med tema skupinama ukrepov okoljsko največjo težo nosita ukrep za spodbujane pokritosti tal na vodovarstvenih območjih in ozelenitev njivskih površin.

Zastopanost posameznih ukrepov za zmanjševanje negativnih vplivov kmetijstva na okolje glede na delež izplačil pokaže, da je več kot tretjina sredstev namenjena ukrepu za integrirano poljedelstvo, gledano širše pa je kar 64 \% vseh sredstev namenjenih integriranim oblikam kmetovanja. 
Graf 7: Struktura izplačil po ukrepih za zmanjšsevanje negativnih vplivov kmetijstva na okolje v letu 2004

Figure 7: The payments structure within the measures for diminishing of negative agricultural influences on the environment

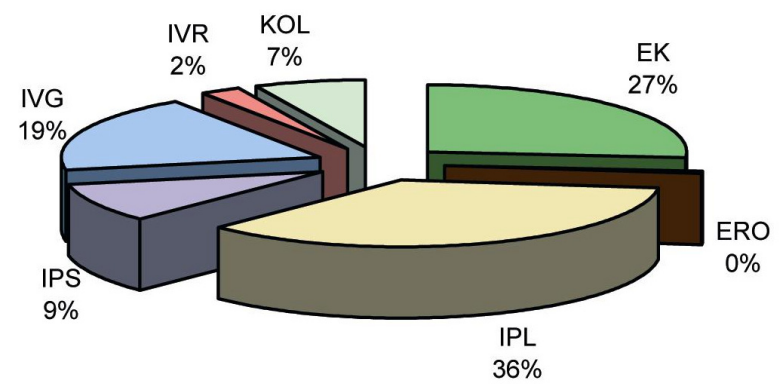

$\begin{array}{llll}\text { EK } & \text { ekološko kmetovanje } & \text { ERO } & \text { zmanjševanje erozije v vinogradništvu in sadjarstvu } \\ \text { IPL } & \text { integrirano poljedelstvo } & \text { IPS } & \text { integrirano sadjarstvo } \\ \text { IVG } & \text { integrirano vinogradništvo } & \text { IVR } & \text { integrirano vrtnarstvo } \\ \text { KOL } & \text { ohranjanje kolobarja } & & \end{array}$

Vir: Agencija RS za kmetijske trge in razvoj podeželja, 2005.

Če primerjamo kmetijsko proizvodnjo in interese kmetijstva izpred desetletij z aktualnim stanjem, vidimo velik preobrat in v smislu sonaravnega razvoja pomemben napredek. Vsi navedeni ukrepi, ki na različne načine spodbujajo okolju prijaznejše oblike kmetijske proizvodnje, imajo pomembne učinke za celoten razvoj podeželskega prostora. Vendar ostaja odprto vprašanje, ali so njihovi učinki optimalni glede na stanje v okolju ter njihovo zastopanost in razporeditev?

Ob upoštevanju aktualne obremenjenosti okolja s strani kmetijske dejavnosti bi bilo pričakovati, da se bodo ukrepi kmetijsko okoljskega programa favorizirali na območjih, kjer se že srečujemo z okoljskimi problemi, ki izvirajo iz kmetijstva. Vendar je razvoj uveljavljanja kmetijsko okoljskih ukrepov ubral drugo pot. Ukrepi za ohranjanje naravnih danosti in tradicionalne kulturne pokrajine so se po večini res uveljavili na območjih, kjer so ti ukrepi smiselni in potrebni (na območjih, kjer je kmetijska pridelava otežena zaradi reliefa in prihaja do zaraščanja ter izginjanja kulturne pokrajine ipd.), v veliki meri to velja tudi za ukrepe za varovanje zavarovanih območij, medtem ko so se ukrepi za zmanjševanje negativnih vplivov kmetijstva na okolje uveljavljali pod vplivom različnih dejavnikov;

- pomembno vlogo je odigrala aktivna vloga kmetijskih svetovalnih služb na posameznem območju, kar do neke mere velja za uvajanje prav vseh ukrepov SKOP-a,

- za uvajanje integriranih oblik kmetovanja so se odločali predvsem kmetje z intenzivnih kmetijskih območij vzhodne Slovenije (ravninska poljedelska in vinogradniška gričevnata) ter jugozahodne Slovenije (vinogradniško-sadjarska območja Brd, Vipavske doline, Koprskega primorja), saj je z minimalnim zmanjšanjem snovnih vnosov (in $\mathrm{s}$ tem pridelka) mogoče dobiti razmeroma visoke dodatne prihodke, 
- $\quad$ ekološko kmetijstvo kot najbolj sonaravna oblika kmetovanja se je razvila predvsem na območjih ekstenzivnega kmetijstva, kjer so bile prilagoditve novi obliki kmetovanja minimalne.

Glede na prostorsko razporeditev in zastopanost izvajanja vseh ukrepov za zmanjševanje negativnih vplivov kmetijstva na okolje ter ob upoštevanju razporeditve vodovarstvenih območij in območij s podtalnico v Sloveniji, se le deloma kaže njihova ustrezna razporeditev. $\mathrm{Na}$ številnih vodovarstvenih območjih in območjih s podtalnico, torej vodno občutljivih območjih, je zastopanost izvajanja omenjenih ukrepov zelo skromna.

Predvsem se slabša usklajenost okoljskih ukrepov z vodovarstvenimi območji kaže v vzhodni in južni kraški Sloveniji. Z vidika največjih zalog pitne vode so ta nasprotja očitna na območju vodnih virov Dravsko-Ptujskega polja, Spodnje Savinjske doline, in deloma Kranjskega polja.

Karta 8: Izvajanje ukrepov za zmanjševanje negativnih vplivov kmetijstva na okolje po deležu KZU po občinah Slovenije leta 2004

Map 8: The implementation of measures for diminishing of negative agricultural influences on the environment (respecting the share of ALU) by Slovenian municipalities in 2004

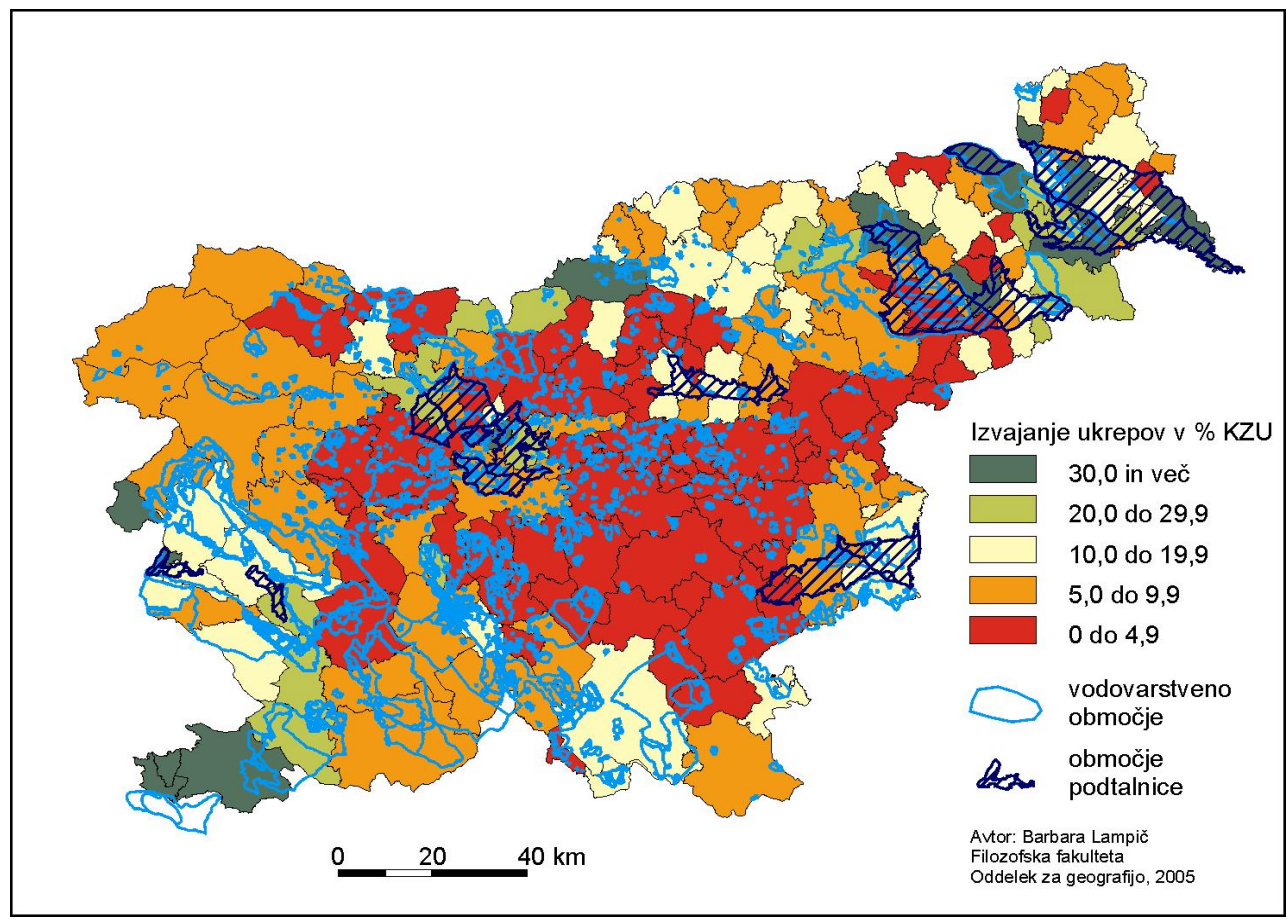

Vir: Agencija RS za kmetijske trge in razvoj podeželja, 2005, MOPE, 2004.

Razmeroma ugodno razporeditev izbranih ukrepov lahko spremljamo na območju podtalnice skrajne severovzhodne Slovenije in na Brežiško-Krškem polju. Skrajno neustrezen je tudi 
delež v južni, kraški Sloveniji, vendar se tu zaradi skromnega obsega obdelovalnih površin in ekstenzivnega kmetovanja ne srečujemo $\mathrm{z}$ okoljskim problemi povezanimi s spornimi snovnimi vnosi.

Dejansko stanje ustrezne zastopanosti ukrepov za zmanjševanje negativnih vplivov kmetijstva na okolje kaže delež površin, kjer se ti ukrepi izvajajo. Predvsem zaskrbljujoča je slika na območjih podtalnice in številnih vodovarstvenih območjih.

$\mathrm{Na}$ ohranjanje okolja in varovanje narave odločilno vpliva uveljavljanje tistih kmetijskih praks, ki v procesu kmetovanja minimalizirajo obseg okoljsko najbolj spornih vnosov, torej sredstev za varstvo rastlin in mineralnih gnojil. V največji meri načelu minimaliziranja vnosov sledi ekološko kmetijstvo, ki predstavlja najbolj sonaravno obliko kmetovanja.

Uveljavljanje ekološkega kmetijstva je torej najbolj priporočljivo in okoljsko upravičeno na tistih območjih, kjer je naravno okolje/naravni viri najbolj občutljivo (območja vodnih virov) oziroma tam, kjer so pritiski kmetijske dejavnosti intenzivni ter dolgotrajni in je prizadeto širše naravno okolje. V slednjem primeru je lahko okolje (prsti) že tako onesnaženo, da ni več primerno za uvajanje ekološkega načine kmetovanja (ostanki škodljivih snovi v prsti). V Sloveniji je takšnih območij razmeroma malo.

Glavna kazalnika neposrednih vplivov izvajanja ukrepov SKOP-a bi bila zmanjšana onesnaženost podzemne vode $\mathrm{z}$ nitrati in pesticidi. Zaradi omejenega števila merilnih mest kakovosti podtalnice, pa tudi razmeroma kratkega obdobja izvajanja ukrepov, si v tej fazi z njima še ne moremo pomagati pri vrednotenju učinkov kmetijsko okoljskih ukrepov.

Lahko pa posredno sklepamo na spremembe v kmetijskih vnosih, če prostorsko prikažemo zastopanost ekološkega kmetovanja.

Podobno kot smo analizirali razporeditev ostalih ukrepov SKOP-a, je smiselno ugotavljati tudi razporeditev ekološkega kmetijstva. Ker pa so dostopni podatki za ekološke kmete na nivoju naselja (Kmetijsko gozdarski zavod Maribor, 2003), lahko zelo nazorno prikažemo razširjenost sonaravnega ekološkega kmetovanja glede na občutljiva in marsikje že preobremenjena območja podtalnice.

Prikaz razporeditve ekoloških kmetij po naseljih kaže, da se je v Sloveniji ekološko kmetijstvo spodbujalo in uvajalo ne toliko zaradi potrebe varovanja našega ključnega vodnega vira, podtalnice, ampak so razvoj ekološkega kmetovanja usmerjali drugi mehanizmi. Velikemu razmahu te najbolj sonaravne oblike kmetovanja, ki je značilen tako za države Evrope kot tudi za Slovenijo, gre pri nas le v manjši meri pripisati okoljski oz. varovalni impulz. Aktualna razporeditev ekoloških kmetij v pretežno hribovitem delu Slovenije je (gledano z vidika razvoja celotnega podeželja) ustrezna, z vidika okolja pa ne sledi dejanskim potrebam niti ciljem ukrepov SKOP-a.

Prostorska razporeditev izvajanja kmetijsko okoljskih ukrepov je predvsem pomembna $\mathrm{z}$ vidika varovanja vode. Ugotavljanje obsega in razporeditve trenutnega vključevanja števila kmetov, predvsem pa obseg površin, na katerih se ti ukrepi izvajajo, kažejo, da kljub razmeroma visokem deležu sredstev, ki je namenjen SKOP-u in skupini ukrepov za zmanjševanje vplivov kmetijstva na okolje, ne moremo govoriti o optimalni in učinkoviti razporeditvi teh ukrepov glede na naravno stanje in vire pri nas.

Dodatno bi ciljno naravnanost kmetijske politike $\mathrm{v}$ varovanje okolja (predvsem $\mathrm{z}$ vidika voda) osvetlila tudi trenutna vključenost kmetov v izvajanje ukrepa »nitratna direktiva«, ki se izvaja od leta 2004, vendar žal teh podatkov nismo uspeli pridobiti. 
Karta 9: Razporeditev naselij z ekološkimi kmetijami in območja s podtalnico v Sloveniji leta 2003

Map 9: The distribution of settlements with organic farms and areas with underground water in Slovenia in 2003

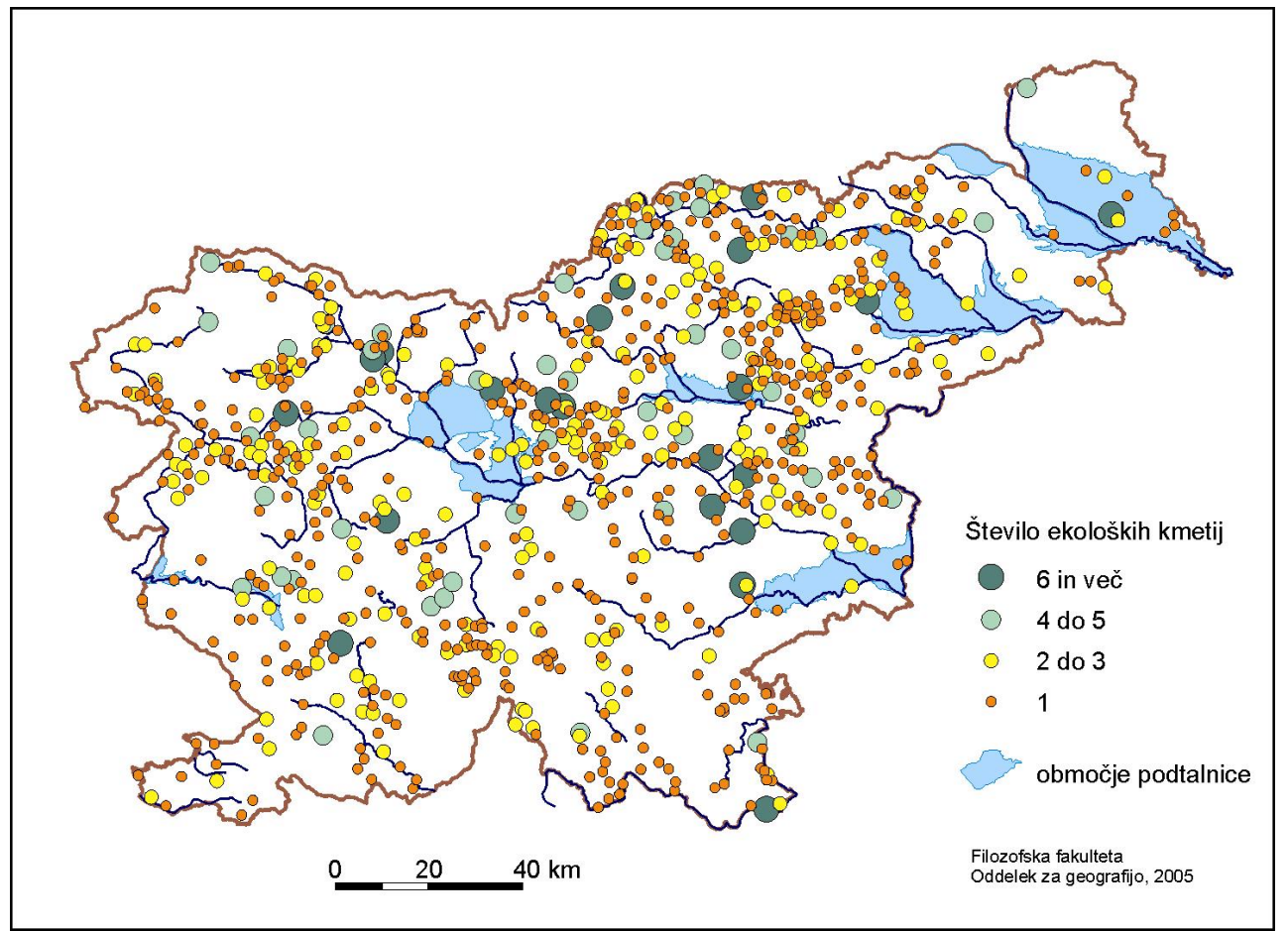

Vir: KGZS, Kmetijsko gozdarski zavod Maribor, 2003, MOPE, 2004.

Če po treh letih vrednotimo učinke kmetijsko okoljskih ukrepov še vedno le po številu vključenih kmetov, velikosti površin in obsegu vloženih sredstev, je v prihodnjih letih pričakovati, da bo potrebno za spremljanje učinkovitosti ukrepov uporabiti kazalnike, ki merijo stanje posameznih sestavin okolja.

S prostorskimi prikazi razporeditve ukrepov in sredstev smo želeli izpostaviti pomen regionalnega pristopa, ki je v naravno-družbeno heterogeni Sloveniji nuja. Uvajanje ukrepov je bilo v Sloveniji premalo ciljno. Izdelan je bil načrt izvajanja na nivoju države, na regionalnih nivojih, kjer bi se morale za izvajanje SKOP-a upoštevati naravne značilnosti in stanje naravnih virov (ter temu slediti z ustreznim naborom ukrepov), pa takšnega načrta ni bilo. Vse preveč je na obseg izvajanja in vrsto izvajanih ukrepov vplivala kmetijsko-svetovalna služba (v pozitivnem ali negativnem smislu).

Vendar Slovenija ni izjema v evropskem merilu, saj se s podobnimi težavami že daljše obdobje srečujejo tudi v marsikateri evropski državi. 


\section{EKOLOŠKO KMETOVANJE KOT MOŽNOST TRAJNOSTNEGA RAZVOJA PODEŽELJA}

Ekološko kmetijstvo lahko opredelimo kot sistem pridelave hrane, ki si prizadeva uskladiti ekonomske, ekološke in socialne zahteve današnjega časa. Govorimo o trajnostni obliki kmetovanja, ki v postopkih pridelave hrane temelji na ravnovesju v sistemu tla/prsti - rastline človek in sklenjenem kroženju hranil v njem. V ekološkem kmetijstvu uporaba mineralnih gnojil in pesticidov ni dovoljena, število živali je omejeno na površino, s čimer se omeji tudi pridelava (in poraba) organskih gnojil.

Kmetje, ki gospodarijo ekološko, skušajo v skladu z naravnimi zakonitostmi in brez uporabe kemično-sintetičnih pripomočkov pridelovati na okolju prijazen način tudi kar najbolj kakovostna živila.

Ekološko kmetijstvo pa ni zgolj pridelava temveč celoten kmetijsko-živilski sektor, ki v zadnjih letih beleži vsakoletno rast v številu kmetij, obsegu površin in pridelave, pa tudi predelave ter tržnega deleža.

V državah EU je bil prvi spodbujevalni dejavnik k povečevanju števila kmetij in obsega ekološke pridelave trg oziroma povpraševanje po ekoživilih, od zgodnjih devetdesetih let 20. stoletja dalje pa je k porasti sektorja bistveno pripomogla tudi uvedba spodbud, kasneje pa okoljskih plačil za ekološke kmetije. V preostalih delih sveta je glavni dejavnik razvoja še vedno trg (Klemenčič s sodelavci, 2005).

Tudi v Sloveniji je bil glavni impulz tržni, saj je bila želja prvih ekoloških pridelovalcev, da bi svoje pridelke lahko ponudili domačemu potrošniku, in sicer z ustreznim potrdilom o ekološkem poreklu. Enako kot v EU pa se je razmeroma hiter porast začel z uvedbo okoljskih plačil v letu 1999.

Razmah ekološkega kmetijstva je v okviru programa ekstenziviranja kmetijstva povezan s pomembnima problemoma kmetijstva $v$ številnih državah EU, in sicer presežki kmetijskih pridelkov ter obremenjenostjo okolja, ki ga je povzročilo (in ga povzroča) energetsko potratno intenzivno oz. »industrijsko« kmetovanje. Ekološki način kmetovanja in pridelo-vanja hrane ponuja vsaj delno rešitev za oboje.

V obdobju največjega razmaha ekološkega kmetijstva so se npr. v Nemčiji najbolj pričele preusmerjati kmetije z območij s težjimi pridelovalnimi pogoji. V programe ekstenziviranja (npr. ekološko kmetovanje) so se lahko vključile brez prevelikih pridelovalnih preusmeritev in sprememb, hkrati pa so že imeli oblikovane strategije trženja ter uveljavljene tržne poti.

Glede na dosedanji razvoj in trende ekološkega kmetijstva, ta postaja vse pomembnejši segment evropske kmetijske pridelave in predelave. Obseg ekološko obdelanih kmetijskih zemljišč (ekoloških certificiranih zemljišč ali zemljišč v prehodu podprtih s subvencijami) je v državah EU-25 ocenjen na 5,5 mio ha ali skoraj 3,4 \% od skupaj 165,2 mio ha kmetijskih zemljišč.

Po visokem deležu ekološko obdelanih kmetijskih zemljišč izstopajo Švedska, Avstrija in Italija. Medtem ko sta prvi dve državi zaradi naravnih razmer kmetijsko razmeroma ekstenzivni in z manjšimi površinami kmetijskih obdelovalnih zemljišč, pa je Italija, kot pomembna evropska kmetijska pridelovalka, izjema. Ostale »velike« kmetijske evropske 
države, npr. Francija, Nizozemska in Belgija, zaradi izrazito specializiranega ter intenzivnega kmetijstva in predvsem tržnih prioritet, razvoju ekološkega kmetovanja ne namenjajo tolikšne pozornosti.

Karta 10: Razširjenost ekološko obdelanih kmetijskih zemljišč v državah EU leta 2002

Map 10: The distribution of the organically farmed land area in the EU countries in 2002

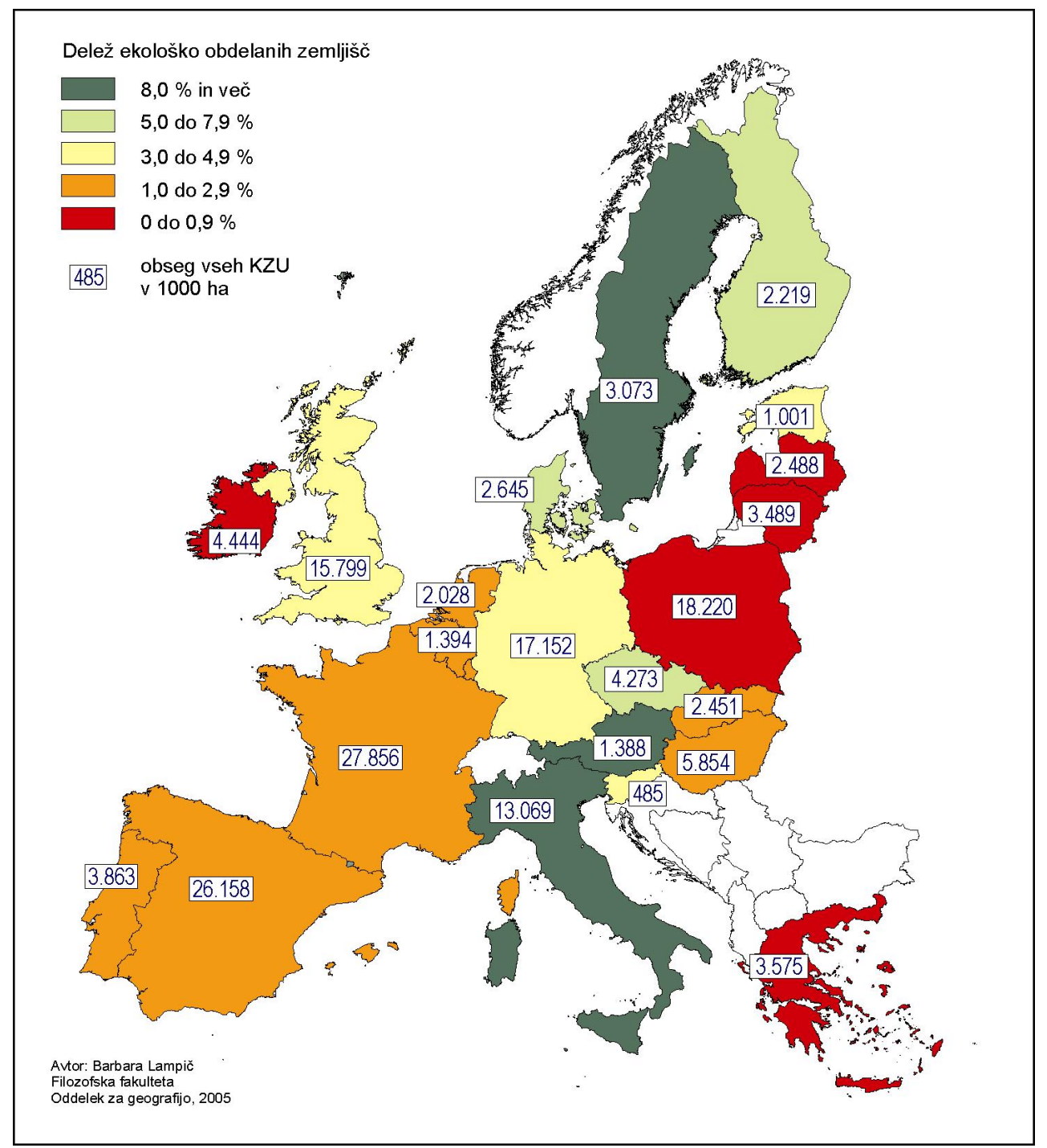

Vir: Lampkin, 2003.

Slovenija se z dobrimi 3 \% ekološko obdelanih kmetijskih zemljišč leta 2002 uvršča v evropsko povprečje, med novimi članicami EU pa skupaj z Češko in Estonijo predstavlja 
države, ki so v pristopnem obdobju razmeroma hitro in uspešno prilagodile kmetijsko zakonodajo in s pravočasnim izvajanjem ukrepov programov razvoja podeželja že uspele razviti in uveljaviti tudi ekološki način kmetovanja. Hkrati pa bi Slovenija glede na slabše naravne možnosti za kmetijstvo, razmere v kmetijstvu in našo predhodno kmetijsko politiko ter razmeroma ekstenzivnega kmetijstva v primerjavi s Češko lahko na tem področju naredila še bistveno večji napredek.

V primerjavi z obsegom ekoloških zemljišč pa je delež ekoloških pridelovalcev, zaradi povprečno večje velikosti ekoloških kmetij, nižji. Če je leta 2002 delež ekološko obdelanih zemljišč v državah EU-25 predstavljal 3,4 \% kmetijskih površin, pa je deleže pridelovalcev znašal le 1,7 \% oziroma 160.458. Izjemi sta Avstrija in Švedska, kjer delež pridelovalcev celo presega delež ekološko obdelanih kmetijskih površin. Po drugi strani pa v Italiji, kjer je na ekološki način obdelanih $9 \%$ vseh kmetijskih zemljišč, ekološki kmetje predstavljajo le $2,3 \%$ vseh kmetov (Lampkin, 2003).

Z 1,4 \% ekoloških kmetov je leta 2002 Slovenija precej zaostajala za evropskim povprečjem, danes pa delež ekoloških kmetij že presega $2 \%$ vseh kmetij v Sloveniji. Seveda pa so ključnega pomena velike regionalne razlike v številu ekoloških pridelovalcev.

\section{Razvoj in trenutno stanje ekološkega kmetijstva v Sloveniji}

Število ekoloških kmetij in delež ekološko obdelanih kmetijskih zemljišč v Sloveniji od leta 1999, ko so uvedli plačila za ekološko obdelane površine kot nadomestilo izpada dohodka zaradi znižanja intenzivnosti pridelave, strmo narašča. Okoljska plačila za ekološko kmetijstvo so bila v tistem času del izvajanja reforme slovenske kmetijske politike (1999-2002), ki je pri vključevanju v EU za Slovenijo našla v usmeritvi v eko-socialnem modelu kmetijstva, kot ga je začela zagovarjati in podpirati tudi EU. Od 2001 dalje je ekološko kmetijstvo eden od ukrepov v SKOP.

Porast ekoloških kmetij in povečanje obsega ekoloških zemljǐč kaže na velik pomen in vlogo politike pri stimuliranju in razvoju ekološkega kmetovanja, treba pa je poudariti, da so posamezni kmetje ekološko kmetovali tudi že pred uvedbo subvencij.

Ekološki kmetje v nadzoru so organizirani v dveh krovnih združenjih, in sicer v okviru Zveze združenj ekoloških kmetov Slovenije (Zveza Biodar, ustanovljena leta 1999), ki šteje 8 regionalnih združenj s skupaj 821 kmetijami v nadzoru ekološke pridelave (2004). Zveza Biodar ima svoje lastne standarde, ki so nekoliko strožji od slovenskega Pravilnika oziroma Uredbe EU št. 2092/91, leta 2004 pa je bilo število uporabnikov znamke Biodar 188. Organizacija za nadzor ekološkega kmetovanja v dogovoru z Zvezo Biodar vzporedno preverja tudi izpolnjevanje njihovih dodatnih zahtev.

Drugo združenje je Iniciativa Demeter Slovenije, ki šteje 37 kmetij v nadzoru ekološke oziroma biološko-dinamične pridelave. Upoštevajo pridelovalne standarde nemške zveze Demeter za biološko-dinamično kmetovanje, število uporabnikov te mednarodne znamke pa je bilo lani 25.

Dobršen del, skoraj 45 \% kmetij v nadzoru ekološke pridelave ni včlanjenih v nobeno združenje ekoloških pridelovalcev. 
Do leta 2005 je v Sloveniji izvajala nadzor ekoloških kmetov in ekološkega načina kmetovanja v skladu s predpisi KGZS, Kmetijsko gozdarski zavod Maribor. Kontrola se izvaja pri vseh ekoloških pridelovalcih, bodisi tistih, ki so že prejeli certifikat ekološkega pridelovalca ali tistih, ki so v še t. im. triletnem prehodnem obdobju. Nadzorna inštitucija posreduje podatke tudi ministrstvu. Od leta 2005 izvajata nadzor ekološkega kmetovanja v Sloveniji dve inštituciji, poleg Kmetijsko gozdarskega zavoda Maribor (Oddelek za kontrolo ekološkega kmetijstva) še Univerza v Mariboru, Fakulteta za kmetijstvo, Inštitut za kontrolo in certifikacijo v kmetijstvu. Trenutno vlada prav na tem kontrolnem področju določena zmeda, saj se morajo ekološki kmetje letos sami odločiti, katera nadzorna inštitucija bo spremljala njihovo pridelavo. Opozoriti velja tudi na dodatne težave pri spremljanju podatkov, ki se bodo sedaj zbirali in obdelovali na dveh različnih inštitucijah.

Preglednica 3: Razvoj ekološkega kmetijstva v Sloveniji od leta 1998 do 2004

Table 3: The organic farming development in Slovenia (from 1998 to 2004)

\begin{tabular}{|l|r|r|r|r|}
\hline leto & $\begin{array}{r}\text { število } \\
\text { ekoloških } \\
\text { kmetij }\end{array}$ & $\begin{array}{r}\text { \% ekoloških } \\
\text { kmetij od } \\
\text { vseh EPK }\end{array}$ & $\begin{array}{r}\text { ha ekološko } \\
\text { obdelanih } \\
\text { zemljišč }\end{array}$ & $\begin{array}{r}\text { \% ekološko } \\
\text { obdelanih zemljišč } \\
\text { od vseh KZU }\end{array}$ \\
\hline 1998 & 41 & 0,05 & 400 & 0,08 \\
\hline 1999 & 343 & 0,40 & 2.400 & 0,49 \\
\hline 2000 & 620 & 0,72 & 5.425 & 1,12 \\
\hline 2001 & 883 & 1,06 & 10.000 & 2,06 \\
\hline 2002 & 1.150 & 1,44 & 15.404 & 3,17 \\
\hline 2003 & 1.354 & 1,76 & 18.855 & 4,16 \\
\hline 2004 & 1.550 & 2,09 & 20.236 & \\
\hline
\end{tabular}

Vir: KGZS, Kmetijsko gozdarski zavod Maribor 2003, 2005, Slabe 2003.

Graf 8: Rast ekološko obdelanih kmetijskih zemljišč in števila ekoloških pridelovalcev v Sloveniji od leta 1998 do 2004

Figure 8: The growth of number of organic producers and organic farmed land area in Slovenia from 1998 to 2004

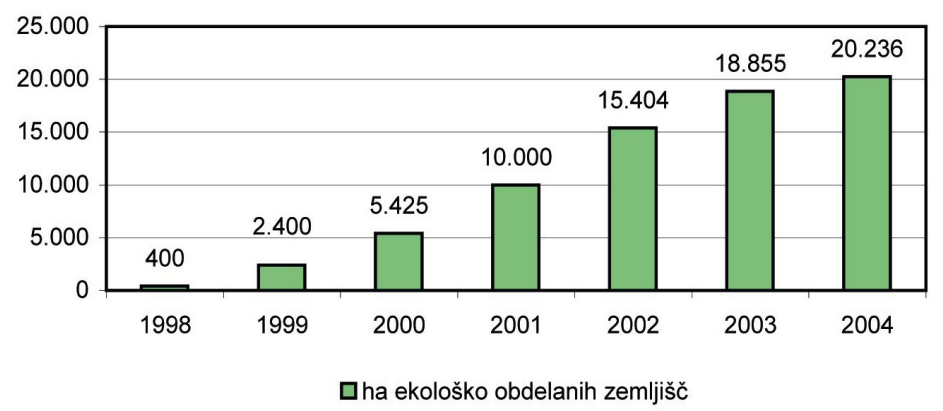




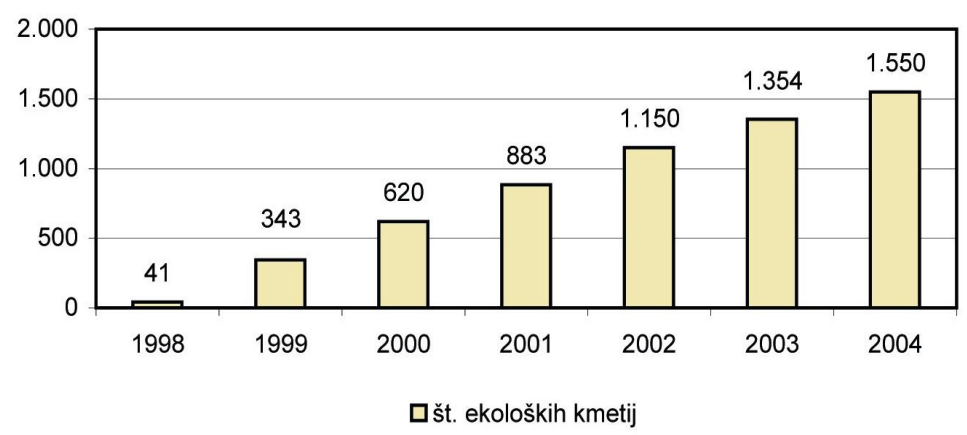

Vir: Kmetijsko gozdarski zavod Maribor, Slabe, 2003.

Način ekološke pridelave, ekološko živinorejo, predelavo in označevanje ekoloških živil pri nas ureja Pravilnik o ekološki pridelavi in predelavi kmetijskih pridelkov oziroma živil (Uradni list, št. 31/2001) na osnovi Zakona o kmetijstvu (Uradni list št. 54/2000), od vstopa v EU dalje pa tudi Uredba Sveta EU 2092/91.

Naraščanje števila ekoloških pridelovalcev in obsega ekološko obdelanih zemljišč v Sloveniji je bilo prva leta po uvedbi okoljskih plačil za ekološko kmetijstvo izjemno hitro, zadnja leta pa se nekoliko umirja. Podobni trendi so se kazali tudi v drugih državah EU.

Večkrat je bilo že poudarjeno, da je potrebno bolj kot absolutno rast upoštevati ustrezno prostorsko razširjenost ekološkega kmetijstva. Tudi na nivoju statističnih regij se kažejo pomembne razlike $\mathrm{v}$ deležu ekoloških zemljišč, glede na pridelovalne pogoje pa tudi $\mathrm{v}$ njihovi strukturi, ki je z vidika ekološke pridelave zelo neugodna.

Graf 9: Struktura ekološko obdelanih kmetijskih zemljišč v Sloveniji leta 2004

Figure 9: The structure of organic farmed land area in Slovenia in 2004

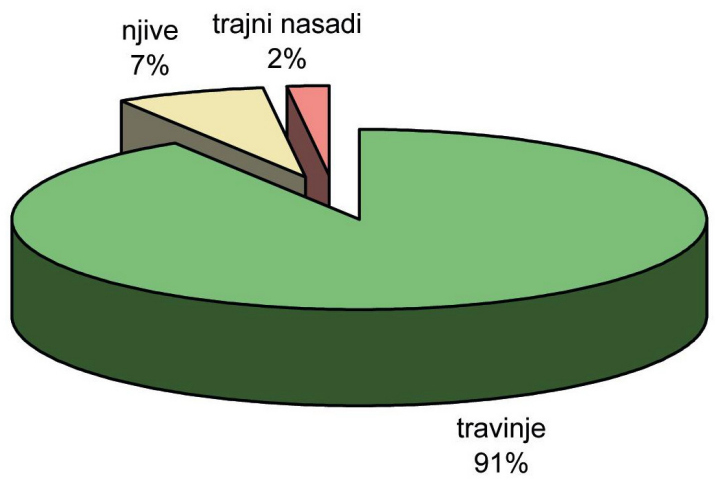

Vir: KGZS, Kmetijsko gozdarski zavod Maribor 2005. 
Od 20.236 ha ekoloških zemljišč (v kontroli), je kar 18.511 ha travnikov (91\%) in komaj 1332 ha njiv (7\%).

Po statističnih regijah (podatki za leto 2003) je bilo (absolutno gledano) največ ekološko obdelanih kmetijskih zemljišč v Goriški, Koroški, Jugovzhodni Sloveniji in Savinjski regiji, po deležu ekoloških obdelovalnih zemljišč pa sta bili v ospredju Obalno-kraška in Koroška regija.

Preglednica 4: Površine in deleži ekološko obdelanih zemljišč po statističnih regijah leta 2003

Table 4: Area and share of organic farmed land area by statistical regions of Slovenia in 2003

\begin{tabular}{|c|c|c|c|c|c|c|c|c|c|c|c|}
\hline $\begin{array}{l}\text { Statistična } \\
\text { regija }\end{array}$ & 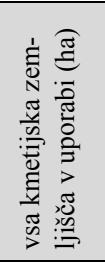 & 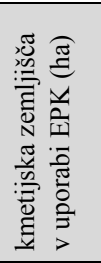 & $:$ & $\begin{array}{l}\stackrel{0}{:} \\
: \\
\text { ○ீ }\end{array}$ & 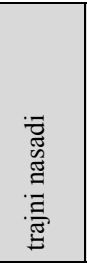 & 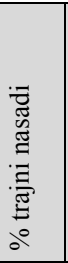 & 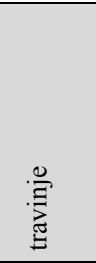 & $\begin{array}{l}\stackrel{0}{\Xi} \\
\underset{\Xi}{\Xi} \\
0^{\circ}\end{array}$ & 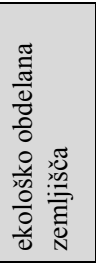 & 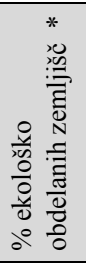 & 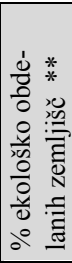 \\
\hline Pomurska & 66236 & 57616 & 160,1 & 0,4 & 3,9 & 0,1 & 48,4 & 0,4 & 212,3 & 0,4 & 0,3 \\
\hline Podravska & 82862 & 72538 & 118,5 & 0,3 & 29,9 & 0,5 & 1194,0 & 3,7 & 1342,3 & 1,9 & 1,6 \\
\hline Koroška & 21578 & 21572 & 76,7 & 2,5 & 0,0 & 0,0 & 2455,4 & 13,4 & 2532,1 & 11,7 & 11,7 \\
\hline Savinjska & 67951 & 67028 & 110,0 & 0,7 & 35,2 & 1,7 & 2344,7 & 4,8 & 2489,9 & 3,7 & 3,7 \\
\hline Zasavska & 6161 & 6132 & 9,8 & 2,2 & 0,4 & 0,6 & 264,8 & 4,7 & 275,0 & 4,5 & 4,5 \\
\hline $\begin{array}{l}\text { Spodnje- } \\
\text { posavska }\end{array}$ & 27895 & 26814 & 27,6 & 0,3 & 13,7 & 0,6 & 347,4 & 2,4 & 388,7 & 1,4 & 1,4 \\
\hline $\begin{array}{l}\text { Jugovzhodna } \\
\text { Slovenija }\end{array}$ & 50231 & 48030 & 122,7 & 0,8 & 94,3 & 3,9 & 2380,8 & 7,8 & 2519,5 & 5,2 & 5,0 \\
\hline $\begin{array}{l}\text { Osrednje- } \\
\text { slovenska }\end{array}$ & 63770 & 61675 & 81,7 & 0,5 & 2,3 & 0,2 & 1406,8 & 3,1 & 1490,8 & 2,4 & 2,3 \\
\hline Gorenjska & 33402 & 31613 & 55,5 & 0,9 & 1,4 & 0,2 & 1656,1 & 6,7 & 1713,0 & 5,4 & 5,1 \\
\hline $\begin{array}{l}\text { Notranjsko- } \\
\text { kraška }\end{array}$ & 20913 & 19630 & 41,0 & 2,2 & 4,2 & 1,0 & 1505,5 & 8,7 & 1550,7 & 7,9 & 7,4 \\
\hline Goriška & 32391 & 31795 & 35,4 & 1,2 & 8,9 & 0,2 & 2609,7 & 10,8 & 2653,9 & 8,3 & 8,2 \\
\hline Obalno-kraška & 12490 & 11697 & 27,8 & 1,3 & 24,4 & 1,0 & 1634,3 & 22,9 & 1686,5 & 14,4 & 13,5 \\
\hline SLOVENIJA & 485879 & 456140 & 866,8 & 0,6 & 218,5 & 0,9 & 17848 & 6,4 & 18855 & 4,1 & 3,9 \\
\hline
\end{tabular}

* upoštevana vsa kmetijska zemljišča v uporabi

** upoštevana vsa kmetijska zemljišča v uporabi kmetij (EPK)

Vir: SURS, 2000, Kmetijsko gozdarski zavod Maribor 2003.

Velik obseg travnikov v ekološki rabi nakazujejo usmerjenost ekoloških kmetij, kjer prevladujejo živinorejske in mešane kmetije. S pridelovalnega vidika je to manj ugodno. Nekoliko višji delež ekoloških njiv, preko $2 \%$, je le v poljedelsko najmanj primernih regijah, Koroški, Zasavski in Notranjsko-kraški. Podobne razmere so tudi pri trajnih nasadih, kjer nekoliko izstopata Jugovzhodna Slovenija in Savinjska regija.

Ekološko kmetijstvo je eden izmed ukrepov Slovenskega kmetijskega okoljskega programa (SKOP), katerega izvajanje ima v prvi vrsti cilj zmanjševanje negativnih vplivov 
kmetijstva na okolje. SKOP je eden od pomembnejših rezultatov reforme slovenske kmetijske politike in predvsem rezultat prilagajanja evropskemu pravnemu redu. Po drugi stani pa ima ta ukrep za cilj tudi pridelovanje zdrave hrane in s tem varovanje zdravja slovenskih potrošnikov. $\mathrm{V}$ ta namen je potrebno ustrezno urediti tudi označevanje in trženje ekološko pridelanih pridelkov in proizvodov, saj bo le na ta način zaščiten tako interes potrošnika, kot interes ekoloških pridelovalcev (skupaj s predelovalci) v smislu varovanja pred nelojalno konkurenco.

Preglednica 5: Izvajanje ukrepa ekološko kmetijstvo v Sloveniji od leta 2002 do 2004

Table 5: The implementation of measure for organic farming in Slovenia (from 2002 to 2004)

\begin{tabular}{|l|c|r|r|r|c|}
\hline & $\begin{array}{c}\text { površina } \\
\text { (ha) }\end{array}$ & $\begin{array}{c}\text { Število } \\
\text { vlog }\end{array}$ & $\begin{array}{c}\text { višina } \\
\text { podpor } \\
\text { (mio SIT) }\end{array}$ & $\begin{array}{c}\text { povprečna višina } \\
\text { podpore v SIT } \\
\text { na ha }\end{array}$ & $\begin{array}{c}\text { povprečna višina } \\
\text { podpore v SIT } \\
\text { na vlogo }\end{array}$ \\
\hline 2004 & 15477 & 1215 & 901,5 & 58.247 & 741.960 \\
\hline 2003 & 15882 & 1158 & 658,1 & 41.438 & 568.326 \\
\hline 2002 & 11393 & 868 & 435,6 & 38.234 & 501.841 \\
\hline
\end{tabular}

Vir: Agencija RS za kmetijske trge in razvoj podeželja, 2005.

Karta 11: Ekološko obdelana kmetijska zemljišča v Sloveniji po občinah leta 2003

Map 11: The organic farmed land area in Slovenia by municipalities in 2003

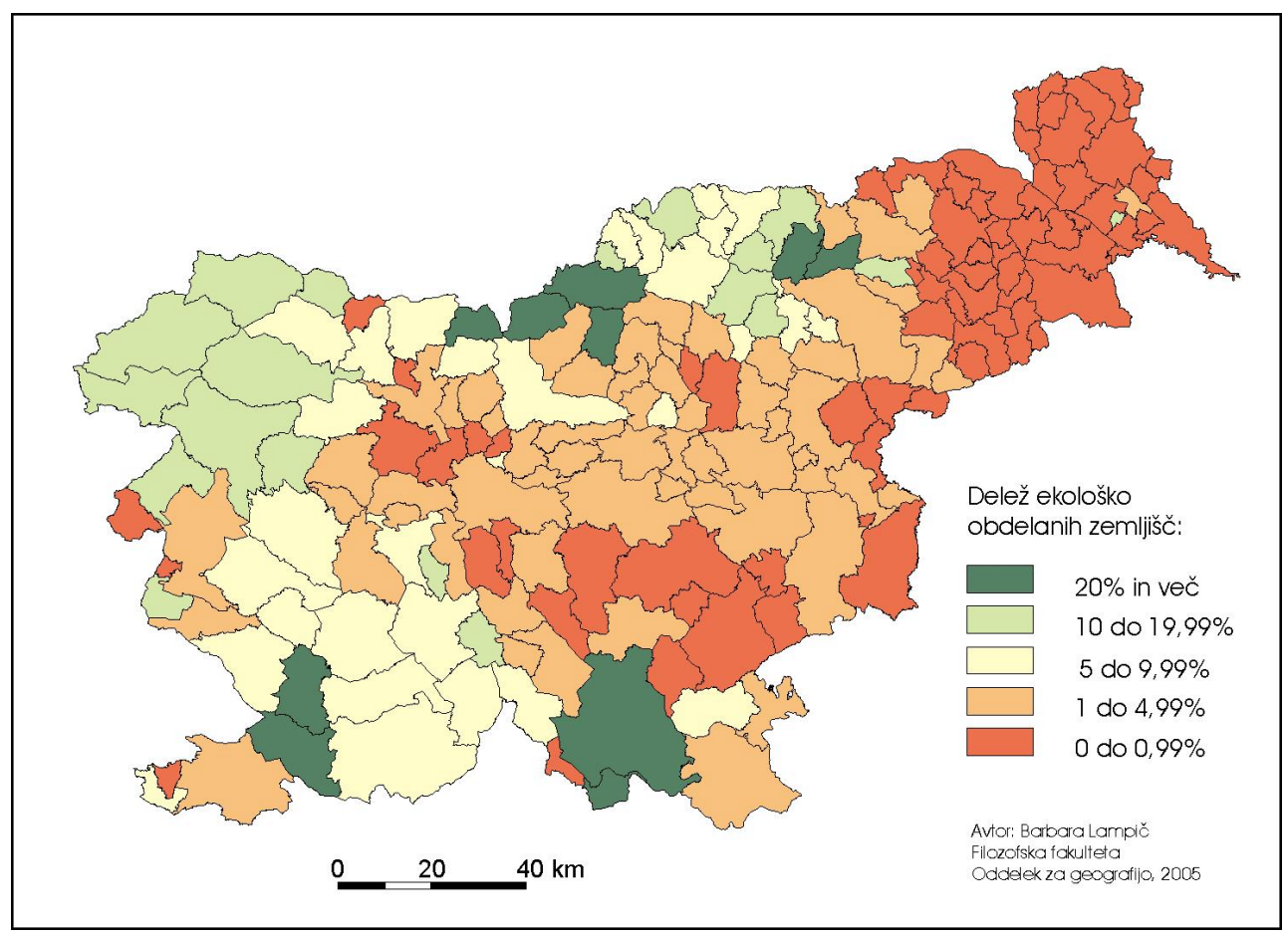

Vir: KGZS, Kmetijsko gozdarski zavod Maribor, 2003. 


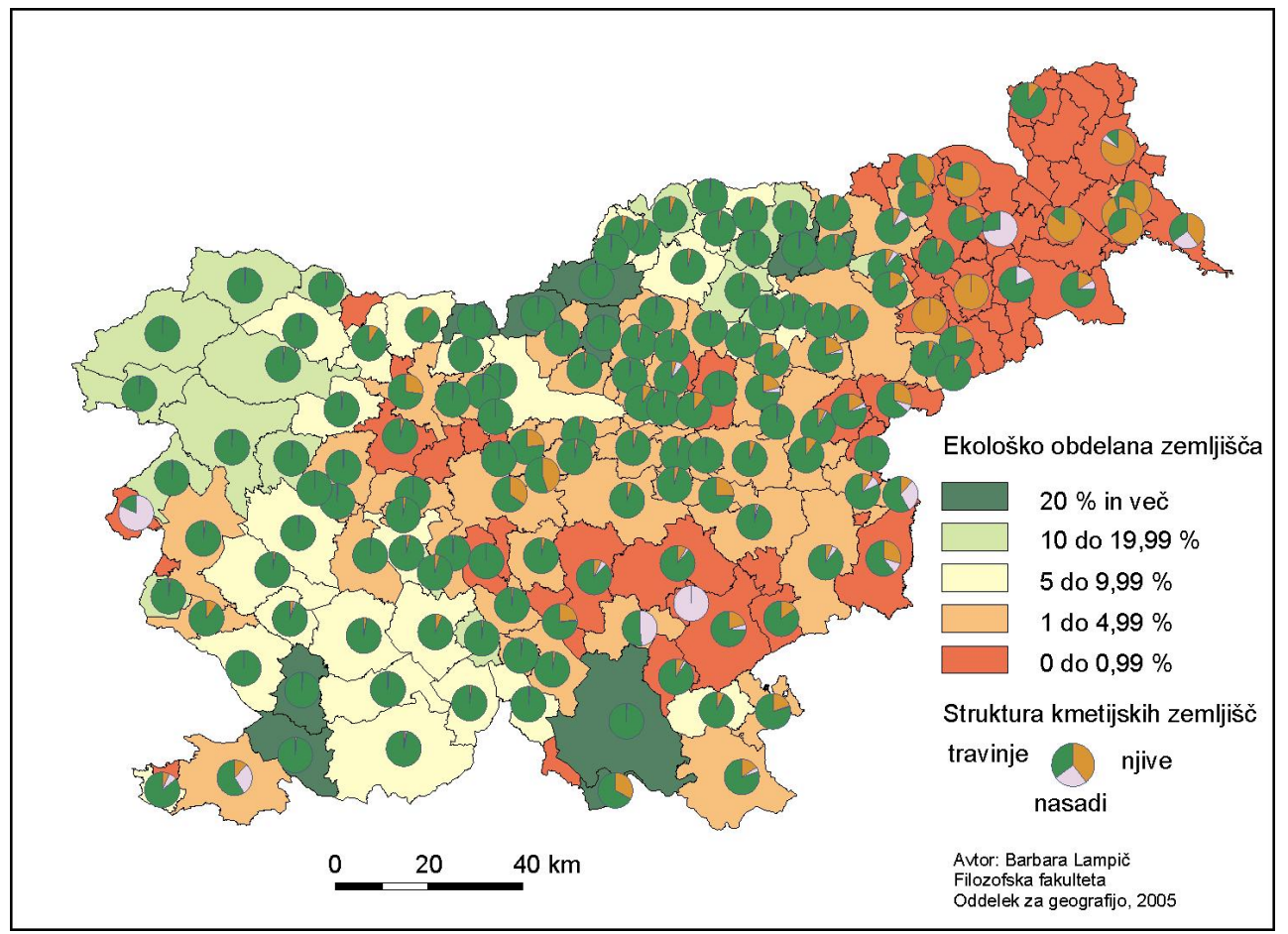

Vir: KGZS; Kmetijsko gozdarski zavod Maribor, 2003.

Dejansko je bilo v letu 2004 za izvajanje ukrepa ekološkega kmetovanja finančno podprto nekaj več kot 1200 kmetov (ARSKTRP, 2005), ki so v povprečju prejeli nekaj več kot 740.000 SIT na kmetijsko gospodarstvo. Konec leta 2004 je po podatkih Kmetijsko gozdarskega zavoda Maribor bilo v nadzor ekološkega kmetovanja vključenih 1550 kmetij (2 \% vseh kmetov), kar pomeni da so bodisi že pridobili ustrezen certifikat oziroma so v obdobju triletne preusmeritve od konvencionalnega k ekološkemu načinu kmetovanja, ki pa je že nadzorovano in v skladu z predpisi. Dejansko pa je kmetij, ki kmetujejo po principih ekološkega kmetovanja, v Sloveniji še nekoliko več.

Kljub hitremu povečevanju števila ekoloških kmetij in tudi absolutni rasti ekološko obdelanih zemljišč, pa nam poleg prikaza razporeditve kmetij po naseljih (glej karto 9) o zastopanosti in dejanski (tudi pridelovalni) vlogi pove prikaz deleža ekoloških zemljišč po občinah. Slovenija se izrazito deli na vzhodni in deloma osrednji, sicer bolj kmetijski del, kjer je v večini občin delež ekoloških zemljišč manjši od $5 \%$ ter zahodna, skrajno severna in južna območja, kjer je delež ekoloških zemljišč višji od 5, v marsikateri občini tudi 10 \% kmetijskih zemljišč. V desetih občinah, vseh kmetijsko zelo ekstenzivnih, pa delež ekoloških zemljišč celo presega $20 \%$. 
Če na nivoju občin ugotavljamo še strukturo ekoloških zemljǐš, je že na prvi pogled očitno, da na kmetijsko ekstenzivnih območjih, kjer se je ekološko kmetijstvo najbolj razširilo in uveljavilo, izrazito prevladujejo travniki. Samo v tistih občinah, kjer je pomen ekološkega kmetovanja po deležu zemljišč skorajda zanemarljiv (pod $1 \%$ ), je struktura bolj pestra in prevladujejo ponekod njive ali trajni nasadi. To velja za občine skrajne severovzhodne Slovenije, Brežiško-Krško ravnino, deloma Belo Krajino, Koprsko primorje in Goriška brda.

Poleg povečevanja obsega ekološko obdelanih zemljišč v zadnjih letih, se je pomembno povečal tudi obseg plačil za ukrep ekološko kmetovanje, in sicer s 435 mio SIT na več kot 900 mio SIT. Ker so upravičenci za plačila le ekološki kmetje, ki so v tekočem letu pridobili pozitivno poročilo o opravljeni kontroli oziroma certifikat in kmetujejo v skladu s Pravilnikom o ekološki pridelavi, je pregled izplačil za ukrep ekološko kmetijstvo po občinah drugačen od prikaza deleža ekoloških zemljišč. Hkrati tudi vsi ekološki kmetje ne vložijo zahteve za podporo, čeprav so v sistemu nadzora za ekološko kmetijstvo. Pri prostorskem prikazu smo namenoma izločili občine, kjer podpor za ekološko kmetijstvo v letu 2004 sploh ni bilo, ki jih je kar 46, večinoma v severovzhodni Sloveniji.

Karta 13: Podpore za ekološko kmetovanje po občinah Slovenije leta 2004

Map 13: The subsidies for organic farming in Slovenian municipalities in 2004

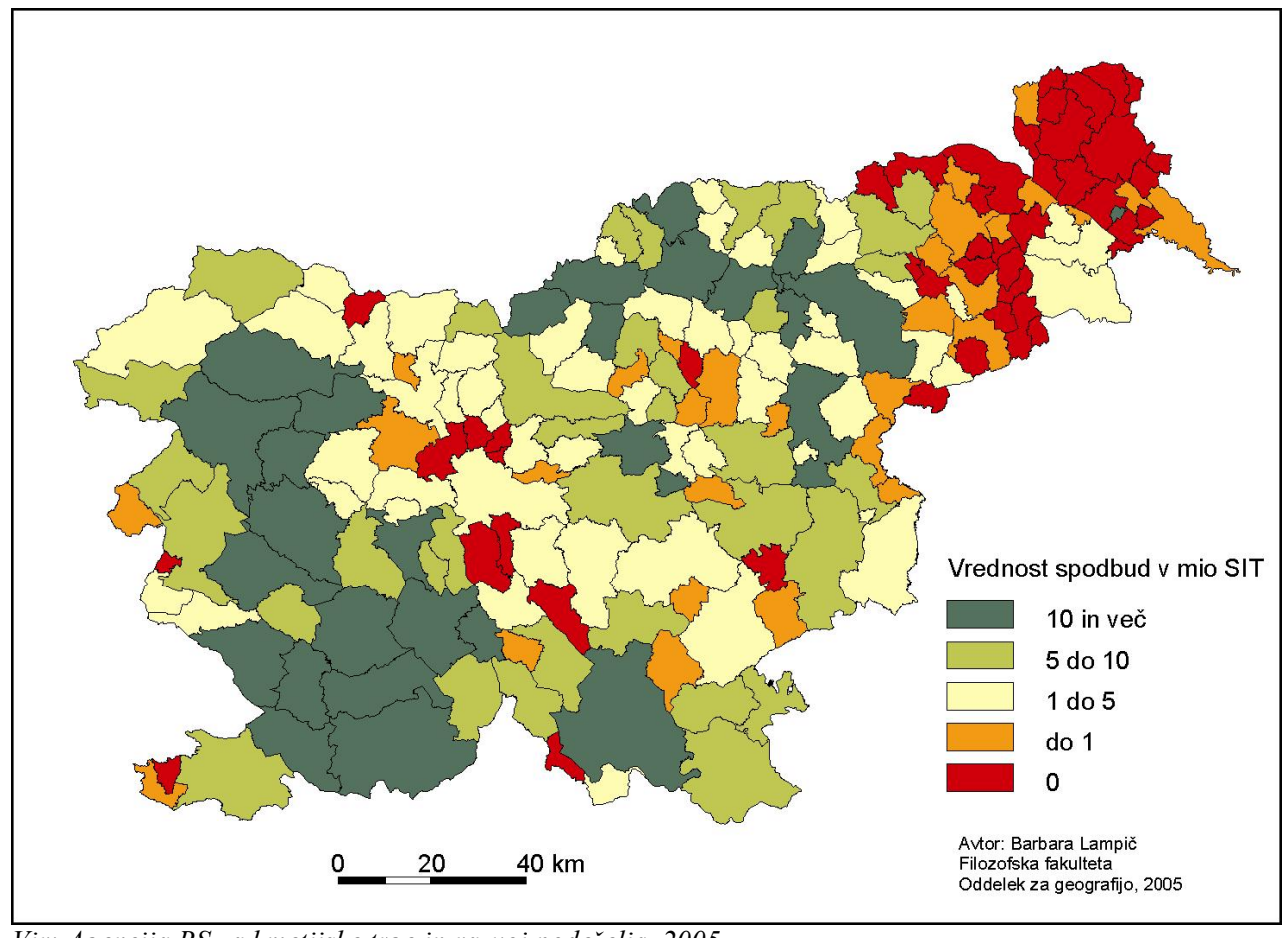

Vir: Agencija RS za kmetijske trge in razvoj podeželja, 2005. 


\section{Multifunkcionalnost ekološkega kmetovanja}

Zaradi povečevanja števila ekoloških kmetij v Sloveniji ter vse večjega povpraševanja na trgu (ter oblikovanih razvojnih dokumentov za ekološki kmetijski sektor na ravni EU in priprave takšnih razvojnih dokumentov v Sloveniji) je smiselno oceniti vlogo, ki jo ta sektor lahko ima za slovenske kmetije in razvoj podeželja. Prav v okviru razvoja podeželja je poudarjena vloga kmetijstva in njegovih funkcij, kjer se ne tržijo več le pridelki (ni najpomembnejša količina pridelave) ampak vedno bolj kvalitetni pridelki. In prav tu lahko pomembno mesto prevzame ekološka pridelava.

Ekološko kmetijstvo ima z vidika kmetijske politike v Sloveniji poudarjeno okoljsko in prek okoljskih plačil tudi socialno komponento. Zagotavljalo naj bi varovanje okolja in ohranjanje kulturne krajine z nadomestili za izpad dohodkov kmetom zaradi omejitev v pridelavi (upoštevanje okolju prijazne pridelovalne tehnologije ter višjih standardov v živinoreji).

Ekološko kmetijstvo igra pomembno vlogo pri celostnem razvoju podeželja, saj ohranja poseljenost in kulturno pokrajino, hkrati pa s pridelavo, ki minimizira okoljsko sporne vnose, trajnostno gospodari s prostorom in drugimi naravnimi viri.

Praksa je pokazala, da je smiselno ekološko kmetijstvo kombinirati še z drugimi dopolnilnimi dejavnostmi na kmetiji, npr. predelavo pridelkov, turizmom na kmetiji ipd. $\mathrm{V}$ smislu diverzifikacije kmetijskih dejavnosti.

Pri oblikovanju koncepta razvoja in usmerjanja ekološkega kmetijstva moramo upoštevati dvoje;

- Ekološki način kmetovanja oblikuje svoj trg ekoloških pridelkov in proizvodov, za katere so potrošniki praviloma pripravljeni plačati višjo ceno. Na ta način ga podpirajo potrošniki, saj jim ponuja kvalitetne pridelke po njihovi izbiri. V tem primeru je razvoj ekološkega kmetijstva podvržen tržnim zakonitostim.

- Zaradi številnih priznanih prednosti ekološkega kmetijstva, predvsem okoljskih, na področju varstva živali, splošnega zdravja prebivalstva, socialnih in razvojnih prednosti, lahko govorimo o t. im. javnih koristih, ki pa se lahko financirajo iz javnih sredstev (podpor). V tem primeru je razvoj ekološkega kmetovanja politična odločitev.

Kljub poudarjenim okoljskim prednostim pa je potrebno izpostaviti tudi nekatere slabosti ekološke pridelave, v prvi vrsti je to (lahko) količina pridelka. Pri preusmeritvi iz konvencionalnega $\mathrm{v}$ ekološko kmetijstvo je predvsem $\mathrm{v}$ prvih letih preusmerjanja opazen velik upad pridelka (donosa), ko pa se z leti, ob postopni uveljavitvi vseh principov ekološkega gospodarjenja, kmetijski ekosistem na novo prilagodi in vzpostavi naravno ravnovesje, se razlike v pridelkih pomembno zmanjšajo.

$\mathrm{Na}$ območjih, kjer prevladuje ekstenzivno, nizko produktivno kmetijstvo in so tudi agrarni vnosi nižji, ob uveljavljanju ekološkega kmetovanja ni pomembnih razlik v pridelku.

\section{Glavne okoljske prednosti ekološkega kmetovanja}

Ker se v ekološkem načinu kmetovanja ne uporablja mineralnih in sintetičnih fitofarmacevtskih pripravkov (sredstva za varstvo rastlin, mineralna gnojila, antibiotiki), je za ohran- 
janje rodovitnosti in zadovoljive količine pridelka ključnega pomena vzdrževanje naravnega ravnovesja in s tem vseh ekosistemskih funkcij.

Preglednica 6: Ocena vplivov ekološkega kmetovanja na okolje v primerjavi s konvencionalnim kmetijstvom

Table 6: The evaluation farming influences on the environment: organic farming compared to conventional farming

\begin{tabular}{|c|c|c|c|c|c|}
\hline $\begin{array}{ll}\text { kazalnik } & \text { vplivi na okolje } \\
\end{array}$ & ++ & + & $=$ & - & -- \\
\hline BIODIVERZITETA & & • & & & \\
\hline Pestrost flore & & $\bullet$ & & & \\
\hline Pestrost favne & & $\bullet$ & & & \\
\hline Pestrost habitatov & & & $\bullet$ & & \\
\hline Kakovost pokrajine & & & $\bullet$ & & \\
\hline PRST & & $\bullet$ & & & \\
\hline$\%$ organske snovi v prsti & & $\bullet$ & & & \\
\hline Biološka aktivnost & $\bullet$ & & & & \\
\hline Struktura prsti & & & $\bullet *$ & & \\
\hline Erozija prsti & & $\bullet$ & & & \\
\hline $\begin{array}{l}\text { TALNA IN POVRŠINSKA } \\
\text { VODA }\end{array}$ & & $\bullet$ & & & \\
\hline Izpiranje nitratov & & $\bullet$ & & & \\
\hline Pesticidi v vodi & $\bullet$ & & & & \\
\hline PODNEBJE IN ZRAK & & & $\bullet$ & & \\
\hline $\mathrm{CO}_{2}$ & & $\bullet$ & & & \\
\hline $\mathrm{N}_{2} \mathrm{O}$ & & & $\bullet$ & & \\
\hline $\mathrm{CH}_{4}$ & & & $\bullet$ & & \\
\hline $\mathrm{NH}_{3}$ & & $\bullet$ & & & \\
\hline pesticidi & $\bullet$ & & & & \\
\hline VNOSI na kmetiji & & $\bullet$ & & & \\
\hline Poraba hranil & & $\bullet$ & & & \\
\hline Poraba vode & & & $\bullet *$ & & \\
\hline Poraba energije & & • & & & \\
\hline
\end{tabular}

- - interval končne ocene

* - manjša zanesljivost zaradi obsega podatkov

Vir: Povzeto po: Organic agriculture, farming and food security, 2002.

Po izbranih kazalnikih so izpostavljene glavne prednosti ekološkega kmetovanja pred konvencionalnim.

Za kmetijstvo imajo prsti kot naravni vir največji pomen, bistveno pa je ohranjanje njihove rodovitnosti. Pozitiven vpliv ekološkega načina kmetovanja se odraža predvsem v 
deležu organske snovi v prsti, večji biološki aktivnosti in manjši eroziji. Razlogi so predvsem naslednji.

- Delež organskih snovi v prsteh, obdelanih po principih ekološkega kmetovanja, je višji zaradi večjega vnosa hranil z organskimi gnojili (mineralna niso dovoljena), hkrati pa organska snov v prsti preprečuje zakisanje.

- Ekološki način kmetovanja zaradi večje biološke aktivnosti prsti izboljšuje njeno strukturo, kar zmanjšuje erozijo.

- Ekološko kmetijstvo pozitivno vpliva na razvoj favne v prsti, kar izboljšuje rastne pogoje.

Največje okoljske pritiske na vode predstavljajo organska gnojila (visoka živinorejska gostota), pretirana in nestrokovna raba mineralnih gnojil, neustrezna pokritost obdelovalnih zemljišč (zlasti jeseni), ozek kolobar, velike količine dostopnega dušika po setvah in onesnaženja s pesticidi. Z izjemo organskih gnojil so vsi ostali pritiski ob ekološkem načinu pridelave bistveno manjši.

$\mathrm{Z}$ vidika biotske pestrosti in kmetijstva velja izpostaviti, da je kmetijstvo stoletja prispevalo $\mathrm{k}$ vrstni raznolikosti in pestrosti habitatov ter oblikovalo številne značilne kmetijske pokrajine. $\mathrm{V}$ drugi polovici 20. stoletja pa je intenzivno kmetijstvo predvsem z visokimi vnosi pesticidov in mineralnih gnojil ter monokulturnim poljedelstvom izrazito negativno vplivalo tako na rastlinsko in živalsko pestrost pa tudi raznolikost ekosistemov. Po podatkih Rdeče liste IUCN je kmetijstvo prizadelo okrog $70 \%$ vseh ogroženih ptic in $49 \%$ vseh ogroženih rastlinskih vrst. (Organic agriculture..., 2002). Ker pa si ekološki način kmetovanja prizadeva uravnovesiti kmetijski ekosistem prav z ohranjanjem ekološkega ravnovesja, je ohranjanje biodiverzitete predpogoj za uspešno sonaravno kmetovanje.

Dosedanje raziskave ugotavljajo, da je energetska poraba na ekoloških kmetijah od 30 do $50 \%$ manjša kot na konvencionalnih, še bolj pomembna pa je struktura energetskih vnosov, ki je okoljsko bistveno ugodnejša. V energetskem (in okoljskem) smislu so bistvene prednosti, da pri ekološkem kmetijstvu ni nobenih energetskih (in snovnih) vnosov v obliki mineralnega dušika, ki je energetsko zahteven pri proizvodnji ter pri prevozu in fitofarmacevtskih sredstev za varstvo rastlin. Pretirana in neustrezna uporaba obojega je okoljsko sporna.

\section{SKLEP - ZAKAJ USMERJATI KMETIJSTVO V SKLADU S PARADIGMO TRAJNOSTNEGA RAZVOJA?}

Položaj in razmere $\mathrm{v}$ slovenskem kmetijstvu so, v primerjavi s kmetijstvom v državah zahodne pa tudi v primerjavi s kmetijstvom v državah vzhodne Evrope, specifične. Slabše naravne razmere za pridelovanje, neugodna posestna in proizvodna struktura, razmeroma majhna specializacija in intenzivnost pridelave in še nekatere karakteristike, so v razvoju slovenskega kmetijstva v primerjavi z »razvitim kmetijstvom« zahodnoevropskih držav skoraj do preloma stoletja pustile svoj pečat »zaostalosti«. V zadnjih nekaj letih smo priče dinamičnim spremembam v smislu prilagajanja naših proizvodnih struktur evropskim. Po 
drugi strani pa so naša agrarna območja $\mathrm{v}$ primerjavi $\mathrm{z}$ razmerami $\mathrm{v}$ vzhodnoevropskih državah kljub vsemu doživljala manj globoke pretrese v smislu popolne strukturne preobrazbe kmetijstva (Knappe, 2001, Tesits, 2004).

Obstoječo situacijo v gospodarstvu in kmetijstvu v Evropi ter trajnostno naravnan prostorski razvoj lahko izkoristimo sebi v prid. Slovenija s slabimi pridelovalnimi pogoji in skromnim obsegom kmetijskih zemljišč $\mathrm{v}$ uporabi (480.000 ha) ne more biti konkurenčna velikim pridelovalnim velesilam. Specifične naravne razmere in obsežna območja velikih naravnih kakovosti (zavarovana območja, območja Nature 2000) skupaj z obsežnimi območji podtalnice (pitna voda) na območjih prodnih ravnin dodatno utemeljujejo smiselnost (in pomen) sonaravne usmeritve kmetovanja.

Dejstvo je, da se Slovenija ne more in ne sme odreči lastnemu kmetijstvu. Kmetijstvu, ki v veliki meri ohranja današnjo podobo (obdelanost) kulturne pokrajine, do neke mere tudi poseljenost, mu lahko ob osnovni proizvodni funkciji pripišemo še turistično in rekreacijsko, varovalno in druge (Cunder, 2001). Visoko kvalitetno naravno okolje skupaj z veliko biološko pestrostjo je trenutno tolikšna prednost, da je ne velja izgubiti zaradi nepremišljenih potez oziroma silne želje sledenju vseh evropskih vzorcev.

Naša kmetijska politika in strategija razvoja podeželja je postala del evropske politike. Znotraj te pa imamo v določeni meri možnost izbire usmeritve $\mathrm{v}$ razvoj, ki bo na koncu nadgradil dosedanje stanje v smislu trajnostnega razvoja - v dobrobit okolju in človeku. Pri strategiji razvoja kmetijstva in usmerjanju sonaravnega razvoja podeželja mora Slovenija izhajati iz specifičnih razmer, saj med evropskimi državami sodimo med tiste z najmanj ugodnimi naravnimi razmerami za kmetijstvo. Skoraj tri četrtine kmetijskih zemljišč sodi med območja z omejenimi možnostmi za kmetijstvo.

Temeljna prednost ekstenzivnih oblik pred visokoproduktivnim kmetovanjem je, da gre pri slednjem za ohranjanje visoke kmetijske proizvodnje na račun zalog in kakovosti različnih naravnih virov, medtem ko so sonaravne oblike kmetovanja, predvsem ekološko kmetijstvo, naravnane $v$ trajnostno rabo vseh ključnih naravnih virov.

Nove priložnosti, ki jih s financiranjem številnih ukrepov iz evropskih kmetijskih jamstvenih skladov ponuja spremenjena SKP, lahko v Sloveniji izkoristimo tudi na področju varovanja in ohranjanja naravnih virov. Seveda je izvajanje kmetijske politike v drugih evropskih državah pa tudi pri nas že pokazalo številne slabosti in težave pri usmerjanju kmetijstva v kontekstu trajnostnega razvoja. Ponujeni so številni mehanizmi/ukrepi, katerih strateško izvajanje vodi v ohranjanje naravnih danosti, kar je gotovo cenejša in manj zahtevna pot kot spreminjanje načetega okolja in virov.

Glavne razloge za spodbujanje razvoja ekološkega, torej sonaravnega kmetijstva v Sloveniji, pa lahko strnemo v naslednjih točkah;

- Strateška odločitev na nivoju države; v ospredju je varovanje neobnovljivih (prostor, prsti) ali izjemno občutljivih naravnih virov, ki so v Sloveniji do neke mere že ogroženi. Intenzivno kmetijstvo je $\mathrm{v}$ veliki meri omejeno na prodne ravnine (poljedelstvo, živinoreja), kjer prihaja do konfliktov $z$ ohranjanjem naravnih virov/podtalnice.

- Spodbujanje razvoja ekološkega kmetijstva je v skladu z razvojnimi usmeritvami slovenske kmetijske politike in seveda $\mathrm{z}$ vse bolj ekološko usmerjenostjo agrarne politike EU. Je najbolj sonaravna oblike kmetovanja in ima za okolje pomembno varovalno funkcijo. 
- Naravne razmere v Sloveniji marsikje onemogočajo intenzivno kmetijsko pridelavo, z 0,09 ha njiv na prebivalca smo ena najbolj ekstenzivnih kmetijskih držav v Evropi. Obstoječe oblike in intenzivnost kmetovanja so v večjem delu države blizu ekološkim, zato so pri preusmeritvi potrebne minimalne prilagoditve v načinu kmetovanja.

- $\quad$ Ekološko kmetovanje se najbolje obnese pri živinorejskih in živinorejsko-poljedelskih kmetijah, te pa v Sloveniji prevladujejo.

- Poleg ohranjanja okolja zagotavlja tak način pridelave tudi kvalitetne pridelke.

- Razpršena poselitev in ohranjena tradicionalna kulturna pokrajina je ena od pomembnih strateških prednosti Slovenije pred ostalimi evropskimi državami, ki pa je zadnja desetletja pod vplivom različnih dejavnikov podvržena hitremu spreminjanju/propadanju. Rešitev je v ohranjanju in spodbujanju tako poselitvene kot kmetijske funkcije podeželja, na katere imajo lahko velik vpliv tudi podpore v kmetijstvu.

- Med ukrepi za zmanjševanje vplivov kmetijstva na okolje ekološko kmetijstvo še ne dosega ustrezne zastopanosti, še manj ugodna pa je njegova trenutna regionalna prisotnost. Prav na tem področju imamo še veliko možnosti in priložnosti, hkrati pa bi država ta kmetijski sektor podprla in spodbudila še z dodatnimi ukrepi.

- Nenazadnje podpore za sonaravne oblike pridelave predstavljajo dodaten dohodek (socialen in ekonomski učinek), z ureditvijo trga in odkupa npr. ekološko pridelanih živil pa lahko pričakujemo tudi večji obseg prodaje in primerno ceno, saj se zavest potrošnikov oziroma družbe v celoti dviguje.

Ob vseh prednostih pa je potrebno izpostaviti tudi nekatere glavne pomisleke, ki se porajajo ob vse bolj eko-socialni usmerjenosti slovenskega kmetijstva;

- Spremembe v kmetijstvu so bile odločilno pogojene s spremenjeno kmetijsko politiko, usmerja jih še vedno v veliki meri trg. Za vzdrževanje kmetijstva na območjih z omejenimi dejavniki za kmetijstvo in uvajanje okolju prijaznejših oblik kmetovanja pa so odločilnega pomena razmeroma visoke finančne spodbude. V Sloveniji je do »preobrata« prišlo hitro, kmetje so se v želji po ponujenih sredstvih usmerjali na različna področja, vendar se je že po nekaj letih pokazalo, da so kontrola in zahteve po dejanskem uresničevanju ukrepov s strani EU stroga. Podobne izkušnje ima sosednja Avstrija, ki je npr. po letih hitre rasti števila ekoloških kmetov leta 1999 zaznala celo njihov upad, kasneje pa se je njihovo število ustalilo in sedaj že nekaj let ekološki kmetje v Avstriji predstavljajo slabo desetino kmetij. Dosedanja hitra rast območij pod ukrepi SKOP-a ter število kmetov, ki so se v program vključili, se bo predvidoma umirila, morda celo nekoliko zmanjšala.

- V Sloveniji so od leta 2001 na voljo le neposredna plačila na enoto zemljišča za nadzorovano ekološko kmetovanje v okviru SKOP-a, ni pa nobenih strukturnih ukrepov, ki bi v celoti spodbujali razvoj sektorja ekološkega kmetijstva in živil. Vzporedno s podporami v obliki neposrednih plačil bo potrebno uvesti tudi druge strukturne ukrepe, ki bodo dolgoročno usmerjali miselnost in delo kmetov v smeri okolju prijaznega kmetovanja, hkrati pa se bodo ti ukrepi morali povezati tudi s tržnim področjem. Ne smemo dopustiti, da bomo postali le »ohranjevalci pokrajine«. V Evropi lahko trenutno govorimo o količinski blaginji na trgu prehrambenih proizvodov, še zdaleč pa ne moremo 
trditi, da je ta blaginja na visoki ravni tudi na področju kakovostnih pridelkov in prehrambenih proizvodih. To vsekakor velja tudi za Slovenijo.

- Natančno bo potrebno opredeliti cilje okoljskih ukrepov. Sedanji sistem nabora ukrepov v okviru SKOP-a je presplošen, cilji premalo jasni, izvaja se vrsta ukrepov, ki dejansko ne izpolnjujejo cilja. V večji meri se ekološko kmetovanje uveljavlja zaradi subvencij in ne zaradi načrtnega zmanjševanja vplivov kmetijstva na okolje ter pridelovanja zdrave hrane, zato se pojavlja vprašanje, $v$ kolikšni meri so podpore ekološkemu kmetovanju sploh okoljski ukrep?

- Razmeroma visoke subvencije lahko kmete uspavajo in postavijo v povsem pasivno vlogo prejemnikov sredstev, ki izpolnjujejo le minimalne standarde (ali pa še to ne, saj kontrola do sedaj ni bila ostra). Samo aktivno udeleženo prebivalstvo je lahko soustvarjalec razvoja.

Slovenija ima na področju kmetijstva veliko odprtih možnosti. Poudariti je potrebno velike regionalne razlike, saj je družbena klima preteklih desetletij marsikje tudi na področju kmetijstva »ubila« željo in potrebo po spremljanju in uvajanju sprememb. Istočasno je vsesplošna tržna naravnanost silila kmete $\mathrm{k}$ pogosto neracionalnemu maksimaliziranju pridelave. Učinki takega kmetovanja so marsikje že vidni, še vedno pa pretežen del Slovenije predstavlja izjemno kakovostno naravno pokrajino, katere vrednost bi se dodatno oplemenitila z načrtnim spodbujanjem sonaravnih oblik kmetovanja.

Naravnanost SKP v vse bolj trajnostni razvoj kmetijstva in podeželja bi lahko optimalno izkoristili tudi mi, pomembno pa je, da znamo tudi sami poiskati svoje lastne strateške prednosti in posebnosti, ki bi Sloveniji dali prepoznavno mesto prav na področju sonaravnega/trajnostnega razvoja podeželja.

\section{Viri in literatura}

Cunder, T., 1998. Kmetijstvo in ohranjanje poseljenosti v Sloveniji. Kmetijstvo in okolje: zbornik posveta. Bled, 12.-13. 3. 1998. Ljubljana. Str. 37-47.

Cunder, T., 2001. Strukturne spremembe v slovenskem kmetijstvu in razvoj podeželja. Podeželje na prelomu tisočletja: Izzivi in problemi. Dela 17. Ljubljana. Str. 123-137.

Erhart, v., Juvančič, L., 2005. Možnost za podeželski prostor. Kmečki glas. 23. marec, 2005. Str. 5.

Erjavec, E., 1997. EU in Skupna kmetijska politika. Slovensko kmetijstvo in EU. Ljubljana. Str. 23-138.

Häring, A., M., s sodelavci, 2004. Impact of CAP Measures on environmentally friendly farming systems: Status quo, analysis and recommenfations; The case of organicfarming. http://europa.eu.int/comm/environment/agriculture/ pdf/

Kerbler-Kefo, B., 2004. Kmetijstvo v razvoju podeželja Evropske unije in Slovenije. Koridorji in poselitev. Urbani izziv 1, letnik 15. Ljubljana. Str. 51-60.

Kladnik, D., Ravbar, M., 2003. Členitev slovenskega podeželja. Geografija Slovenije 8. Ljubljana. 196 strani. 
Klemenčič, M. M., Lampič, B., Perpar, A., Potočnik Slavič, I., Slabe, A., 2005. Strukturni problemi in razvojni izzivi slovenskega podeželja v evropski razsežnosti. FF, Oddelek za geografijo, BF, Inštitut za agrarno ekonomiko, Inštitut za trajnostni razvoj. Končno poročilo. CRP Konkurenčnost Slovenije 2001-2006. Ljubljana.

Knappe, E., 2001. The changing importance of agriculture in the rural areas of the former GDR. Podeželje na prelomu tisočletja: Izzivi in problemi. Dela 17. Ljubljana. Str. 162-173.

Kosi, D., 2004. Sonaravno kmetijstvo v Sloveniji. Geografski vestnik 76-2. Ljubljana. Str. 43-52.

Lampič B., 2000. Izbrani razvojni in okoljevarstveni problemi slovenskega podeželja z vidika sonaravnega razvoja. Geographica Slovenica 33-1. Ljubljana. Str. 157-198.

Lampič, B., 2002. Agrarno obremenjevanje okolja na Slovenskem v energetski osvetlitvi (na izbranih primerih). Doktorska disertacija. Filozofska fakulteta v Ljubljani. Ljubljana. 208 strani.

Lampič, B., Potočnik Slavič, I., 2004. Rural development programme in Slovenia from the regional disparities perspective. V: Assessing rural development policies of the CAP : proceedings of the 87 th EAAE-Seminar. Vienna.

Lampkin, N. H., Dabbert, 2., 2003. Organic farming - can policy and markets mix? AgraEurope Outlook 2003 Conferene »Reform, Trade and Sustainability«. London.

Merrington, G., Parkinson, R., Redman, M., Winder, L., 2002. Agricultural Pollution Environmental problems and practical solutions. London, New York. 243 strani.

Nacionalni program varstva okolja, 1999.

Operativni program za varstvo voda pred onesnaženjem z nitrati iz kmetijske proizvodnje za obdobje 2004 do 2008. Osnutek za obravnavo. 2004.

Organic agriculture, environment and food security, 2002. ur. Nadia El-Hage Scualabba, Caroline Hattam. Roma.

Plut, D., 2004. Okoljske razsežnosti Strategije gospodarskega razvoja Slovenije (20012006). Geografski vestnik 76-1. Ljubljana. Str. 67-76.

Plut, D., Adamič, M., Kryštufek, B., Lampič, B., Medved, S., 2004. Vrednotenje vloge naravnih virov (okoljskega kapitala) v Strategiji razvoja Slovenije z vidika konkurenčnosti in kakovosti življenja. Filozofska fakulteta. Oddelek za geografijo. Ljubljana. Str. 116

Program razvoja podeželja za Republiko Slovenijo 2004-2006. Uradni list RS. Št. 116/2004.

Rejec Brancelj, I., 2000. Podeželska okoljsko občutljiva območja. Geographica Slovenica 33-1. Ljubljana. Str. 203-214.

Rejec Brancelj, I., 2001. Kmetijsko obremenjevanje okolja v Sloveniji. Ljubljana. 104 strani.

Rejec Brancelj, I., 2003. Kmetijstvo v Sloveniji z vidika obemenjevanja okolja. Geografski vestnik 75-2. Ljubljana. Str. 53-64.

Ribbe, L., 2002. Observations on the Environmental Compatibility of the EU Agrcultural Budget. EURONATUR, AbL. Bonn.

Slabe Anamarija, 2003. Slovenia; Building an environmentaly friendly agriculture. Ecology and Farming, No. 33. FOAM Head Office, Okozentrum Imsbach, Tholey-Thely.

Strategija razvoja slovenskega kmetijstva, 1993. 
Sušin, J., 2002. Gnojenje na vodovarstvenih območjih. Tehnološki list 85/2002. Ljubljana. 53 strani.

Špes, M., 2000. Geografske značilnosti pokrajinsko ranljivih območij v Sloveniji. Geographica Slovenica 33-1. Ljubljana. Str. 9-40.

Tesits, R., 2004. Characteristics of rural unemployment in South-Transdanubia (Hungary). Geografski vestnik 76-2. Ljubljana. Str. 33-41.

Tome, B., 2005. Prihodnost razvoja podeželja, predlog Evropske komisije za obdobje 20072013. Mednarodna konferenca Prenos dobrih praks pri razvoju podeželja v EU - Po poteh dediščine Dolenjske in Bele krajine. 16.-19. 2. 2005. Prispevki predavateljev. Otočec. Str. 19-22.

Zakon o kmetijstvu (Zkme). Uradni list RS, št. 54, 2000.

Zakon o vodah (ZVO). Uradni list RS, št. 67/2002.

Medmrežje:http://www.useu.be/agri/budget.html

Medmrežje:http://www.arsktrp.gov.si/index.php?stran=novica\&novica=10\&start=1\&PHPS ESSID=673833f7e24973629083bae97636ed6a; Neposredna plačila 2004 na hektar kmetijskega zemljišča v uporabi po občinah.

Medmrežje:http://www.eisfom.org/press/may04fig.pdf; Certified and policy-supported organic and in conversion land area (ha) in the enlarged EU.

Podatkovna zbirka. KGZS, Kmetijsko gozdarski zavod Maribor. Ekološke kmetije v Sloveniji vključene v kontrolo ekološkega kmetijstva, 2003, 2005.

Podatkovna zbirka (2005). Agencija RS za kmetijske trge in razvoj podeželja. Obseg izvajanja ukrepov SKOP 2001 - 2004.

\section{AGRICULTURE AS THE OPPORTUNITY FOR SUSTAINABLE DEVELOPMENT OF SLOVENE RURAL AREAS}

\section{Summary}

Environmental as well as agricultural legislation has experienced substantial changes as a result of general ecologisation of the society during the last decade, in response to numerous environmental burdens of agriculture. The role of agriculture in rural areas has changed significantly, since it has been attributed numerous new functions, in addition to the primary productional also the spatial-settlement, cultural, social, ecological, etc.

The paper is focusing first of all on the looking for a connection between the agricultural activity and environment/natural resources. Since the key conflicts between the environment and agriculture and the current agricultural burdening are rather well known, the main stress is laid upon the establishment of possible positive environmental effects of agriculture on the environment. These are represented in the biggest part by sustainable forms of agriculture, stimulated in Slovenia from 2001 on by the Rural development programme through the implementation of agri-environment measures. In spite of the increased environmental stance of the whole agricultural policy, a detailed spatial analysis of the extent and representation of agri-environment measures indicated disparities in relation to the protection and preservation of our key natural resources. 


\section{NEW PROSPECTS OF AGRICULTURE AND RELATIONSHIP TO THE ENVIRONMENT}

Changes in the Common Agricultural Policy (CAP) made agriculture a great deal »responsible« for the development of rural areas in the widest sense, and at the same time it takes over the important environmental role.

Main cornerstones of the CAP, which becomes more and more environmentally-oriented, are represented by the 1992 reform, the content of which was upgraded by Agenda 2000, and the latest, however the most important from the viewpoint of the environment or agricultural environmental pressures is the 2003 reform. Decoupling direct payments from agricultural production represents a significant turning point from the former explicitly marketing orientation, which is essential for the encouraging and existence of extensive agricultural systems.

Also Slovene agriculture, its direction, intensity level, size and proprietal structure, number of agricultural holdings and persons employed in agriculture, are subject to signifycant changes as a result of integration into the EU and implementation of the CAP. These changes shall be gradually reflected also in the landscape. The environmental role of agriculture should be also under great influence of the implementation of measures of the Slovene agri-environmental programme. The basic question which is still to be answered is whether the direction of agricultural policy and the trend of agriculture in Slovenia correspond to the protection and conservation of our basic natural resources?

\section{AGRICULTURE AND THE ENVIRONMENT IN SLOVENIA}

Economic significance of agriculture in EU Member States and in Slovenia is still in decline. Decline in its economic role should also be the reason for decline in the economic and social role of rural areas in general (Kovačič, 1995). From 2003 on agriculture, forestry and fishery contribute below $3 \%$ of GDP and are forecasted to be even decreasing (UMAR, 2003).

Conditions in the Slovene agriculture have significantly changed over the last fifteen years. The extent of utilised agricultural areas has not changed over the last years, which makes Slovenia with its about 172,000 ha of arable lands (less than 0,19 ha per inhabitant) to remain one of the agricultural the mot extensive countries in Europe. However small changes in the use do not influence big changes in the number and size of agricultural holdings. According to data of Agricultural inventory in 2000 there were 86,467 such holdings in Slovenia, in 2003 the number was only 77,149 (Statistical Yearbook, 2004). The number of all agricultural holdings with less than 10 ha of utilised agricultural areas (UAA) has absolutely decreased and the umber of agricultural holdings with less than 3 ha of UAA has relatively decreased. Also the number of livestock did practically not change between 2000 and 2003, however the average number of livestock per agricultural holding with livestock increased significantly from 6,2 LUs to 6,9 LUs, and on the other hand the share of agricultural holdings with less than 10 LUs decreased. These data indicate that specialisation of livestock farms is relatively fast, which is confirmed also by the information that an increased number of livestock is reared on farms of more than 20 ha. The percent of livestock 
reared on such farms in the year 2000 was $35 \%$ of all LUs, to increase in the year 2003 to $41 \%$.

Changes in the number and size of farms are followed by changes in agricultural orientation. Mixed arable farming-stockbreeding farms, which are so characteristics for our country are in disappearance, the number of oriented and specialised ones to be increasing.

Different forms of conventional intensive agricultural systems of high productivity are mostly wasteful in terms of the increased soil degradation, its decreased fertility, water quality, biodiversity and the extent of the services of ecosystem. Maintenance of high agricultural productivity goes on the account of reserves and quality of various natural resources, while sustainable forms of agriculture, in particular organic farming, being oriented into sustainable use of all main natural resources.

Geography was carrying out systematic monitoring of the extent and intensity of agricultural burdening by different Slovene landscapes (and different agricultural systems) in the nineties of the $20^{\text {th }}$ century. Comparing the results of energetic intensity of agriculture, where establishing by way of synthesis the agricultural burdening of the environment, indicates that material inputs in Slovene agriculture have been gradually stabilised. Regional differences in material-energetic inputs are lowering, the significance to be given to the difference in relation to energy consumption and the structure of inputs between conventional and organic farming.

\section{SUSTAINABLE (CLOSE-TO-NATURE) DEVELOPMENT - OPPORTUNITY FOR AGRICULTURE?}

Conversion of intensive agricultural production into materially extensive, sustainable forms of agriculture (e.g. organic farming) is one of the so-called environmental priorities of the strong sustainability, since involving a measure or measures aiming at reducing or avoiding pressures on the environment. Due to the rather extensive less favoured areas for agriculture $(73,9 \%$ of utilised agricultural areas) with mostly extensive forms of agriculture, its conversion into, for example, organic farming shall not represent any serious problems. Environmental conflicts with agriculture are the most considerable in spatially limited areas of fertile gravel plains, which are occupied by intensive arable farming and stockbreeding, thus the extensification of agricultural production should be the most reasonable in these conflict areas.

Agri-environmental program, performed within the framework of the Rural development programme, involves 21 agri-environment measures (from 2004 on) and represents the key mechanism for the stimulating and implementing the sustainable forms of agricultural production. The whole distribution of funds by individual measures indicates that the majority of the agri-environmental programme $(42 \%)$ is intended for the conservation of natural conditions and biodiversity and traditional cultural landscape. Practically the same amount $(41 \%)$ is intended for the highly environmental measures, such as lowering the negative impacts of agriculture on the environment. This involves a group of seven measures, supporting the extensive and more sustainable forms of farming, and representing the reaction to the already present negative environmental impacts of agriculture. Four of the said measures are intended for the support of integrated forms of agriculture (arable farm- 
ing, vinegrowing, fruit growing and horticulture), two for the preservation of ecosystemic functions (maintenance of crop rotation and decreasing the erosion in vinegrowing and fruit growing), the measure for stimulating the organic farming to be the most effective and wholesome measure from the environmental point of view, however significantly lagged behind by integrated forms of agriculture in view of the amounts of payments, the number of applications and the extent. $17 \%$ of the funds for the implementation of the Slovene agri-environmental programme are intended for the conservation of protected areas.

According to various indicators, agricultural policy is laying an increasing stress upon environmental protective component of agriculture. Furthermore, it is to be pointed out that the amount of funds intended for the Slovene agri-environmental programme within the framework of the Rural development programme still lags behind in comparison to European average (about $55 \%$ in 2002) and to numerous European countries.

However it should be underlined that from the point of view of environmental and spatial effects of the above-mentioned measures what is the most important is their appropriate spatial distribution, which should base on natural characteristics and the condition of the key natural resources. With regard to basic aims or the intention of the Slovene agrienvironmental programme to, in addition to protecting the human health, popularise agricultural production, which is oriented into sustainable use of natural resources, preservation of biodiversity and of typical cultural landscape, we were looking for the connection between the measures carried out and those natural resources, which are essential for inhabitants and for the sustainable development, and the reserves or quality of which have already been started on by the present agricultural production.

If looking briefly through the situation in the field of carrying out the measures of the renewed common agricultural policy, in particular carrying out the measures of the Slovene agri-environmental programme, which represents one of the major steps of Slovenia towards the harmonisation of the Slovene legislation with the EU legislation in the field of agriculture, rather fast implementation of supports are indicated also in Slovenia where regional differences are apparent. Upon a rough review no direct connection may be established between the needs and requirements of natural environment/natural resources and real agricultural burdening on the one hand and the real representation of measures and means intended for the preservation and improvement of the natural quality of our country on the other hand.

\section{CONCLUSION}

In the last few years Slovenia has been facing dynamic changes in the sense of adapting its agricultural production structures to European. However, on the other hand, if comparing Slovene agrarian areas with conditions in East-European countries, the first were not subject to such deep shocks in the light of total structural transformation of agriculture (Knappe, 2001, Tesits, 2004).

However we can take advantage of the present situation in the European economy and agriculture, as well as of sustainable oriented spatial development. Slovenia, characterised by its unfavourable production conditions and limited extent of utilised agricultural areas (480,000 ha), is not able to compete with big productional great powers. Specific natural 
conditions and extensive areas of great natural qualities (protected areas, Nature 2000 areas), together with areas of underground water (strategically important water reserves) show the reasonability and the need for sustainable orientation of agriculture. Extensive sustainable forms have the advantage over the high-productivity agriculture through sustainable use of all key natural resources, the intensive high-productivity agriculture to maintain high agricultural production on account of their reserves and quality.

However sustainable agriculture in Slovenia should be stimulated due to the following primary reasons, stated herebelow:

- Sustainable agriculture is in line with development orientations of the Slovene agricultural policy and with the EU agrarian policy, which is more and more ecologically oriented. Organic farming is the most sustainable form with a considerable protective function for the environment.

- Strategic decision taken by a country, where the protection of exhaustible natural resources (space, soil) or of extremely sensitive natural resources, which are already threatened in Slovenia to a certain extent, is pointed out.

- There are quite some places in Slovenia where the intensive agriculture is not possible due to natural conditions, with 0,19 ha of fields per an inhabitant being one of the most extensive agricultural European countries. The present forms and intensity of agriculture are mostly close to sustainable/ecological, thus minimal adaptations in the farming practice shall be needed for the conversion.

- Organic farming is proven to be the most successful at livestock and livestock-arable farming farms, which are prevailing in Slovenia.

- Sustainable farming does not ensure only conservation of the environment but also production of quality products.

- Dispersed settlement and conserved traditional cultural landscape is one of the important strategic advantages of Slovenia in comparison to numerous European countries, however during the last centuries having been, as a result of various factors, subject of rapid changing/disappearing. The situation may be solved through preservation and stimulation of settlement as well as agricultural function of the rural area, which may be influenced in great deal also by supports in agriculture.

- Organic farming is not yet correspondingly represented among other sustainable forms of sustainable agriculture (in particular in relation to integral forms of agriculture), its present regional representation being even less favourable. In this field still a number of opportunities are opened, however the state could support this sector by means of introducing additional measures.

- Finally, supports for sustainable forms of production represent additional income (social and economic performance), however organisation of the market and the purchase of, for example, organically produced foodstuff can also give rise to anticipated greater extent of sale and a reasonable price, since the awareness of consumers or the society is rising.

Yet, along with all the advantages, the more and more eco-socially oriented Slovene agriculture give rise to certain concerns, which should be pointed out: 
- Changes in agriculture were substantially subject to the changed agricultural policy, still directed in great deal by the market. Maintenance of agriculture in less favoured areas and the introduction of environmentally friendly agriculture depend significantly on relatively high financial incentives. Slovenia experienced the »turning point« quite quickly, farmers desiring the offered funds directing into various fields, however not many years had passed until the strict control and demands for the actual realisation of the measures by the EU were shown. Rapid increase of the areas under the Slovene agri-environmental programme and the number of farmers included in the programme is likely to be slowed down, maybe even decreased.

- In Slovenia from the year 2001 only direct payments per unit of land are available for controlled organic farming within the framework of the Slovene agri-environmental programme, however there are no structural measures which would provide a wholesome stimulation for the development of the sector for organic production and foodstuff. Supports in form of direct payments shall have to be accompanied by other structural measures, which would direct, on a long-term basis, the farmers' way of thinking into environmentally friendly agriculture, thus such measures shall have to be connected with the market field. We should strive against getting into the role of being only the "conservators of landscape". As regards the European market in food pro-ducts, it may be characterised by quantitative welfare, however it cannot on no account be considered as a high-level welfare also in the field of quality products and food products. This certainly holds good also for Slovenia.

- Objectives of the environmental measures should be specified. The present system of the selection of indicators within the Slovene agri-environmental programme is too general, the objectives are not defined well enough, and indicators for the monitoring of effects are too general as well. Introduction of organic farming owes mainly to subsidies and not methodical reduction of the effects of agriculture on the environment and the production of healthy food, therefore the question is to which extent are the supports to organic farming considered as environmental measure?

- Rather high subsidies may make farmers passive recipients of funds, fulfilling only minimum standards (or not even these, since up till now control has not been so severe). However only actively participating population may be the co-creator of development.

Slovenia has many open opportunities in the field of agriculture, in particular its connecting with other activities. Great regional differences should thus be considered since, as a result of social climate of the last centuries, the desire and the need for following and implementing changes have often been »killed« also in the field of agriculture. At the same time owing to the general market orientation farmers were forced to irrationally maximise their production. The effects of such farming may already be seen at many places, however most of Slovene landscape is still characterised as the natural landscape of extremely high quality, the value of which could be still enriched by way of a planned directed stimulation of sustainable agriculture as one of the important factors of sustainable development of rural areas. 